\title{
Taxonomic revision of Cinnamomum (Lauraceae) in Borneo
}

\author{
Soh Wuu-Kuang ${ }^{1}$
}

Key words

Borneo

Cinnamomum

Lauraceae

taxonomy

\begin{abstract}
Twenty-six species of Cinnamomum are recognised in Borneo. Seventeen species are endemic to Borneo. Fifteen species names are newly reduced to synonymy. The species nomenclature, description, distribution, ecology, vernacular names and uses are given.
\end{abstract}

Published on 21 November 2011

\section{INTRODUCTION}

There are about 250 species of Cinnamomum in the tropical and subtropical regions, mostly in Asia and some in South and Central America, and Australia (Mabberley 2008). To date, 628 binomials of the genus have been published on the International Plant Names Index (http://www.ipni.org, last accessed 30 October 2010) and 33 of these are attributed to species occurring in Borneo. Kostermans was the pioneering figure in the revision of Malesian Lauraceae in the 20th century. His work, although not complete, has been ground-breaking and has set the momentum towards the family revision in Malesia. He had published many precursory papers on Malesian Lauraceae, some of which are relevant to Cinnamomum (Kostermans 1952, 1957, 1964, 1969, 1970b, 1986, 1988). His last major revision of Cinnamomum was published in Gingkoana in 1986, focussing on species from the eastern Malesian region to Australia (Sulawesi, the Philippines, Moluccas, New Guinea, Solomon Islands, Pacific Area and Australia). Other revisional studies of Bornean Cinnamomum have generally been subsets of geographically broader revisional work in the Malesian region (Blume 1851, Miquel 1858, 1864, Cammerloher 1925).

Cinnamomum is usually readily recognised by trinerved and fragrant leaves, paniculate inflorescences, flower with nine stamens and fruits seated on a cupule. At suprageneric level based on chloroplast and nuclear DNA studies, Cinnamomum is placed together with other Neotropical genera (Aiouea p.p., Mocinnodaphne, and Ocotea p.p.) in a clade within Cinnamomeae (Chanderbali et al. 2001). Asian Cinnamomum was shown to be monophyletic and sister to the New World species (Chanderbali et al. 2001). At the infrageneric level, there is no comprehensive molecular study, and nucleotide sequences are available for only a few wild and frequently cultivated species. Meissner (1864) recognised two sections, namely section Malabathrum characterized by opposite or subopposite leaves, trinerved or triplinerved leaf venation and non-perulate buds and the other section is Camphora which is mostly with alternate leaf arrangement, pinnate leaf venation and perulate buds. The section Camphora is mostly restricted to the Northern Hemisphere. This division has been accepted by some authors who have worked in the Malesian Lauraceae (Gamble 1912, Ridley 1924, Kostermans 1986).

\footnotetext{
Botany Department, School of Natural Sciences, Trinity College, Dublin, Republic of Ireland; e-mail: wuukuang@gmail.com.
}

\section{MATERIALS AND METHODS}

Herbarium specimens from the following herbaria were examined; BM, BO, KEP, KEW, L, NY, P, PNH, SAN, SAR, SING, SNP and US. Some of the observations were made during fieldwork in Sabah and Sarawak. Flowers and fruits from herbarium specimens were revived in boiling water for observation and measurement.

Only important references relevant to the species and Borneo are given. Full references for each species up to 1964 can be found in Bibliographia Lauracearum (Kostermans 1964). The specimens were databased using BRAHMS v6.04 (http://dps. plants.ox.ac.uk/bol/). The species distributions were mapped using DIVA-GIS v6 (http://www.diva-gis.org/). The coordinates for mapping species distribution were gathered from herbarium labels, gazetteers (Joseph \& Wong 1995, Mohizah et al. 2006), maps and NGA Geonet Names Server database (http://earth-info.nga.mil/gns/html/index.html, last accessed 30 October 2010).

\section{CINNAMOMUM}

Cinnamomum Schaeff. (1760) 268, 269 (nom. cons, fide Dandy 1967: 40); Blume (1826) 568; Merr. (1921) 272; Cammerl. (1925) 446; Merr. (1929) 77; Masam. (1942) 308; F.G.Browne (1955) 211; Kosterm. (1957) 233; (1964) 1267; P.F.Burgess (1966) 332; J.A.R.Anderson (1980) 222; Kosterm. (1986) 1; Kessler \& Sidiy. (1994) 152; Rohwer (1993) 381; Coode et al. (1996) 151; Argent et al. (1997) 308; Beaman et al. (2001) 398; van der Werff (2001) 135.

(see Kostermans (1986) for all generic synonyms and references)

Shrubs or trees to $50 \mathrm{~m}$ tall, with or without buttresses. Bark, root and crushed leaves often with a characteristic smell of cinnamon (cinnamic aldehyde), cloves (eugenol), sassafras (safrole), camphor (camphor) or a combination of these odours. Twig terete or angular, usually apically angular or subangular, 1-5 $\mathrm{mm}$ diam, hairy or glabrous. Terminal buds not perulate or rarely perulate, glabrous or hairy. Leaves opposite to subopposite or rarely alternate, rarely at twig-end the leaves are arranged closely in spiral; triplinerved, trinerved or rarely penninerved, if trinerved or triplinerved, the lateral veins ascend toward the leaf tip or between $1 / 2-2 / 3$ of the lamina length; mature blades glabrous above, glabrous or hairy below, frequently glaucous below, margin entire; major intercostal veins scalariform, subscalariform or rarely reticulate; minor intercostal veins reticulate or scalariform. Inflorescences axillary or subterminal; paniculate-cymose with 1-3 order branching, flowers of the ultimate 
branch arranged in cyme, rarely racemiform; rachis angular; bracts caducous or persistent. Flowers bisexual, trimerous, appressed hairy; receptacle tube shallow, 0.5-3 mm deep; perianth lobes 6 in 2 whorls, equal; fertile stamens 9 , in 3 whorls, filaments $1 / 4-3 / 4$ the length of stamen; anthers 2- or 4-locular, if 4-locular the locules of the upper pair smaller than that of the lower pair, anther of the first and second whorls of stamens introrse, those of the third whorl extrorse-latrorse; third whorl stamens with 2 stipitate reniform glands attached on each side of the filaments; the gland stalks free or fused with the filaments; staminodes 3 , in the fourth whorl, stipitate, hairy, apex sagittate or hastate; ovary superior, stigma subpeltate, peltate, discoid or trilobed. Fruits ellipsoid, obovoid, ovoid to globose seated on cupule, drupaceous, epicarp waxy, glabrous, pericarp thin or thick, often fragrant; cupule small to well-developed, subtending the lower part of the fruit; perianth lobes persistent, partly persistent or caducous. Seeds 1 per fruit, smooth, glabrous; endosperm absent; germination hypogeal.

\section{NOTES ON SELECTED MORPHOLOGICAL CHARACTERS}

\section{Indumentum}

The hairs vary from curly to straight adpressed and sparse to dense which often occur on the terminal bud and flower. The occurrence of hairs on leaf and twig are prominent and diagnostic for some species (e.g., C. angustitepalum Kosterm., C. javanicum Blume and $C$. tahijanum Kosterm.) while for other species they are less prevalent, minute and visible only by hand lens (e.g., C. iners Reinw. ex Blume, C. kerangas Kosterm., C. rhynchophyllum Miq. and C. subcuneatum Miq.).

\section{Terminal bud}

The terminal bud of the Bornean species, with the exception of C. porrectum, are non-seasonal and non-perulate; their terminal bud, like most tropical species, exhibit continuous growth and therefore do not leave behind a collar of scars at the axil of shoot. In C. porrectum, the terminal bud is perulate with seasonal budscales. The bud is covered with tiered budscales which eventually fall off after flushing, leaving behind a collar of scars at the axil of the young shoot. This type of seasonal budscale is also frequently found in temperate Cinnamomum species (e.g., C. camphora (L.) J.Presl and C. japonicum Siebold).

\section{Leaves - Fig. 1}

There are three types of major leaf venation patterns in Cinnamomum; the majority of Bornean species (20 spp.) have acrodromous lateral veins that extend to the tip or base of acumen parallel to the leaf margin (Fig. 1a) but in the second type (C. burmannii (Nees \& T.Nees) Blume, C. calciphilum Kosterm., C. kinabaluense Heine, C. sintoc Blume and C. verum J.Presl), the lateral veins extend until $1 / 2-2 / 3$ of the lamina length (Fig. $1 \mathrm{~b})$. In the latter case, the remaining area at the leaf apex where the lateral veins terminate is accommodated by pinnate secondary veins. The lateral veins extension is taxonomically useful for species identification. The third type is penninerved which is found in C. porrectum (Fig. 1C). Klucking (1987), who has surveyed the leaves of 239 Cinnamomum species, found that $56 \%$ belong to the first type, $30 \%$ to the second type and $14 \%$ to the third type.

Most of the Bornean Cinnamomum species examined are trinerved (21 spp.) while some species are both trinerved and triplinerved (C. corneri Kosterm., C. crassinervium Miq., C. calciphilum, C. pendulum Cammerl., C. politum Miq., C. suavenium Miq., C. subcuneatum Miq., C. tahijanum and C. verum J.Presl) and only a small number are strictly triplinerved (C. burmannii, C. grandifolium Cammerl., C. kinabaluense and C. sintoc).

\section{Inflorescences - Fig. 2}

The term subterminal is used here when the inflorescences are axillary but positioned at the twig-end at the axils of distal leaves. Most inflorescences are paniculate-cymose with flowers arranged in cymes (Fig. 2a) except for $C$. racemosum Kosterm. which is racemiform in that the individual flowers are arranged alternately or suboppositely along the main axis or lateral branches (Fig. 2b).

\section{Flowers}

The anthers of most species are strictly 4-locular (12 spp.) but there are some species with strictly 2-locular anthers (3 spp.). Other species exhibit some variation in the number of anther locules within the same species and in different specimens. There are species with either 2- or 4-locular anthers in all flowers (4 spp.). In other species, the first and second whorl anthers are 4-locular while the third whorl anthers varies from 2- or 4-locular (6 spp.) (see Table 1). The number of anther locules together with other vegetative characters can be useful in delimiting species.
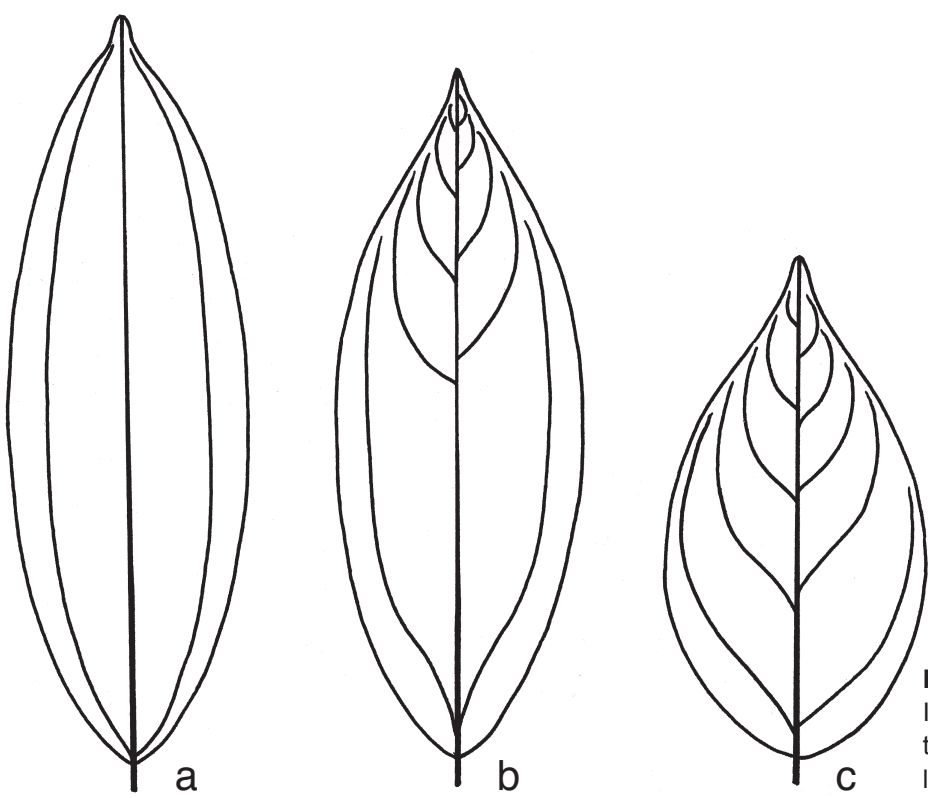

Fig. 1 Leaf type of Cinnamomum Schaeff. species in Borneo. - a. Type I, showing acrodromous lateral veins extending to the leaf apex near the tip; b. Type II, showing acrodromous lateral veins extending until $2 / 3$ of leaf length; c. Type III, penninerved leaf. 

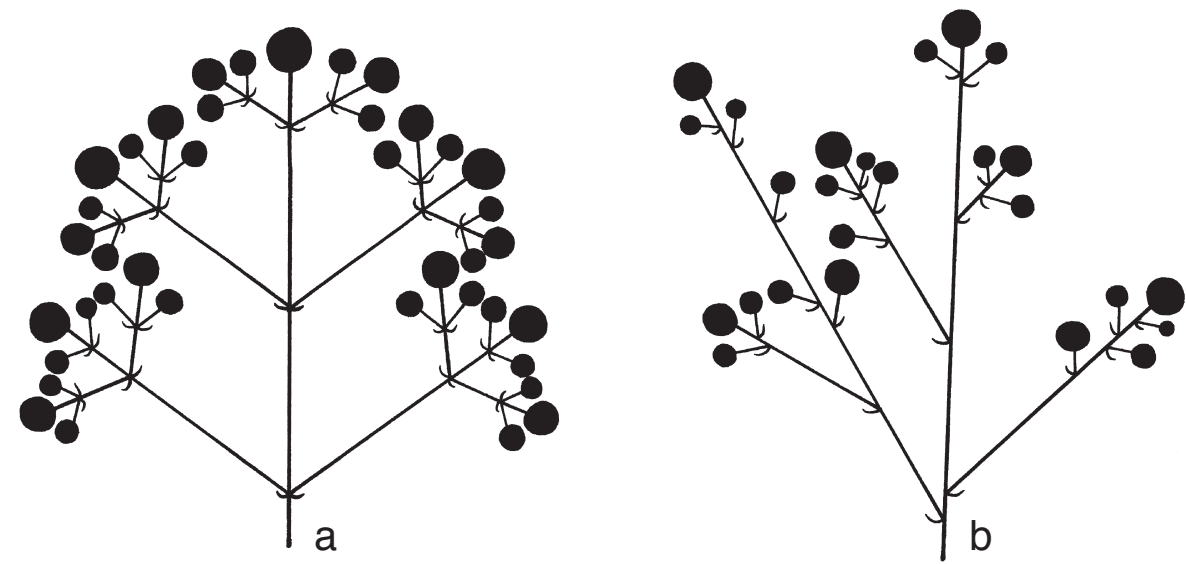

Fig. 2 Inflorescence type of Cinnamomum Schaeff. species in Borneo. - a. Paniculate-cymose inflorescence; b. racemiform inflorescence.
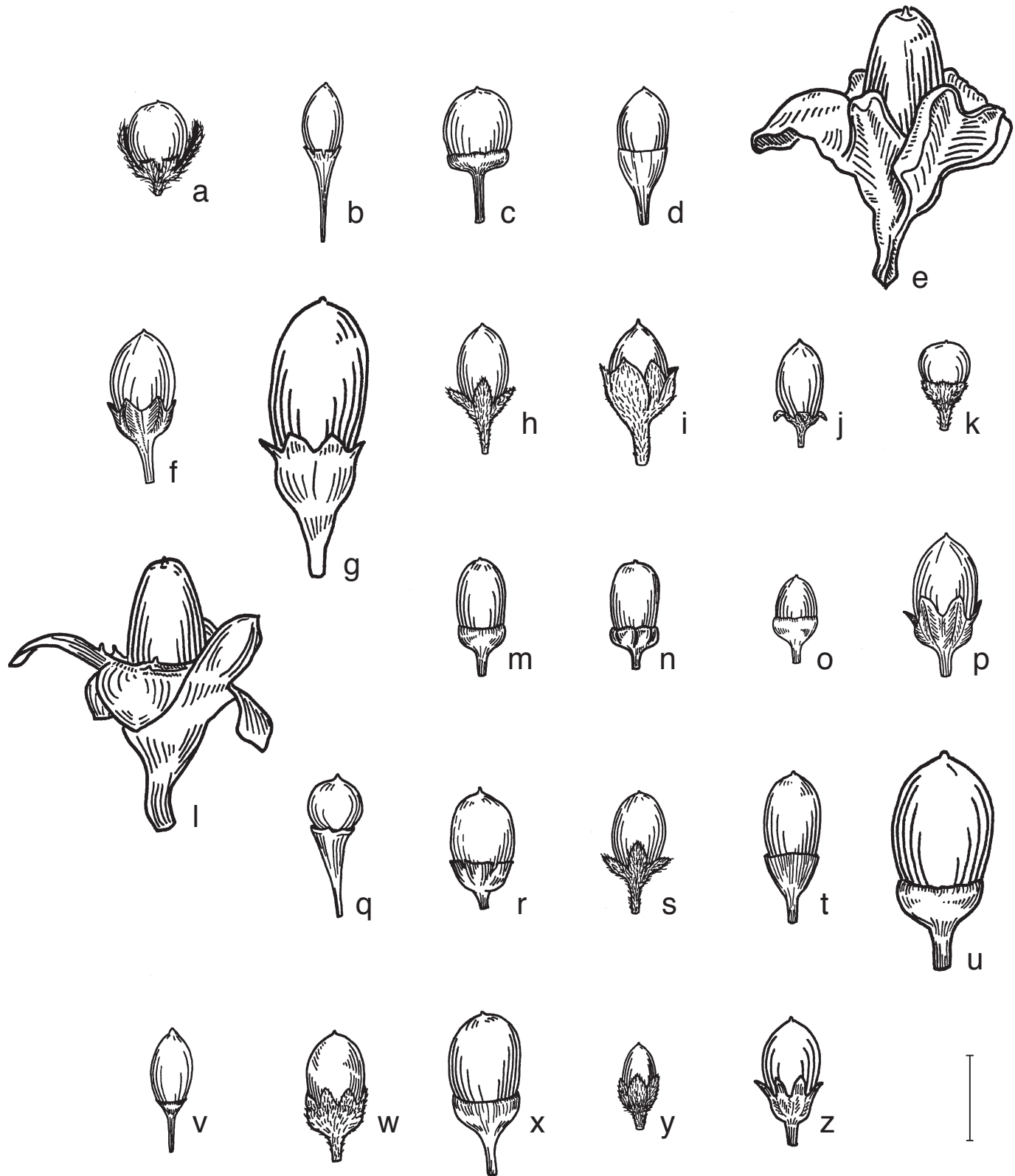

Fig. 3 Fruits of Cinnamomum Schaeff. species in Borneo. - a. C. angustitepalum Kosterm.; b. C. burmannii (Nees \& T.Nees) Blume; c. C. calciphilum Kosterm.; d. C. corneri Kosterm.; e. C. crassinervium Miq.; f. C. cuspidatum Miq.; g. C. grandifolium Cammerl.; h. C. iners Reinw. ex Blume; i. C. javanicum Blume; j. C. kerangas Kosterm.; k. C. kinabaluense Heine; I. C. lawang Kosterm.; m. C. paiei Kosterm.; n. C. pendulum Cammerl.; o. C. percoriaceum Kosterm.; p. C. politum Miq.; q. C. porrectum (Roxb.) Kosterm.; r. C. racemosum Kosterm.; s. C. rhynchophyllum Miq.; t. C. sintoc Blume; u. C. soegengii Kosterm.; v. C. subavenium Miq.; w. C. subcuneatum Miq.; x. C. sublanuginosum Kosterm.; y. C. tahijanum Kosterm.; z. C. verum J.Presl. - Scale bar = 1 cm. 
Table 1 Summary of the number of anther locules in Bornean Cinnamomum. (Cinnamomum paiei is not included here because flowering material has not been seen.)

\begin{tabular}{ll}
\hline Number of anther locule & Species \\
\hline 2-locular anther in all stamens & C. grandifolium, C. kinabaluense, C. rhynchophyllum. \\
4-locular anther in all stamens & C. angustitepalum, C. burmannii, C. calciphilum, C. kerangas, C. lawang, C. porrectum, \\
& C. racemosum, C. sintoc, C. soegengii, C. subavenium, C. sublanuginosum, C. verum. \\
$\begin{array}{l}\text { The first and second whorl anthers 4-locular, } \\
\text { the third whorl anthers varies from 2- or 4-locular }\end{array}$ & C. crassinervium, C. iners, C. pendulum, C. percoriaceum, C. politum, C. subcuneatum \\
2- or 4-locular anther in all stamens & C. corneri, C. cuspidatum, C. javanicum, C. tahijanum
\end{tabular}

\section{Fruit - Fig. 3}

The cupule which is derived from the enlarged receptacle tube is unique and is an important diagnostic character in distinguishing Cinnamomum species. The variation in cupules among different species can be seen in their shape, size, texture, depth and perianth lobes persistency. The most notable difference is in the perianth lobe persistency; in some species the lobes are fully (e.g., C. iners and C. javanicum) or partially intact (e.g., C. angustitepalum and C. burmannii), while in other species they fall off and leaving behind a smooth cupule rim (e.g., C. pendulum and C. sintoc).

\section{TAXONOMY}

There are two sections within Cinnamomum, both present in Borneo; sect. Camphora and sect. Cinnamomum (= sect. Malabathrum Meisn.). Section Camphora is represented by C. porrectum and it differs from other Bornean species in having alternate leaf arrangement, pinnate leaf venation and perulate buds. All other species fall into sect. Cinnamomum by having opposite or subopposite leaves, trinerved or triplinerved leaf venation and non-perulate buds. In this paper, no attempt was made to recognise any infrageneric groups within sect. Cinnamomum because many morphological characters overlap. Although fruit type is unique for many species or groups of species, its homology is uncertain. Many species of the same fruit type can vary considerably in vegetative characters, for example the species with peculiarly enlarged fleshy cupules (C. crassinervium and C. lawang Kosterm.) show variation in vegetative characters such as leaf size, shape and indumentum.

\section{ECOLOGY}

In Borneo, Cinnamomum species are widely distributed and occur from lowland to montane forest at altitudes to $2000 \mathrm{~m}$ in both secondary and primary forest on various soil types. Cinnamomum calciphilum is the only species in Borneo restricted to limestone habitat.

\section{USAGES}

The wood of Cinnamomum is a source of timber traded under the name camphorwood or medang (Malay). The wood is used for construction, furniture making, plywood and interior finishing. Several species are cultivated commercially for cinnamon (C. verum) and cassia (C. burmannii, C. cassia J.Presl, C. loureirii Nees and C. tamala T.Nees \& Eberm.), which are used as spice and source of essential oils. Cinnamomum camphora (L.) J.Presl is cultivated as important source of camphor. Some species are planted as landscape trees (e.g., C. iners) (Ibrahim et al. 1995, Flach \& Siemonsma 1999, Nguyên et al. 1999, Nirmal Babu et al. 2003).

In Borneo, different parts of the plant including the leaves, bark or root are used on either on their own or in conjunction with other plants as medicinal treatments for headache (C. crassinervium), stomach ache (C. crassinervium, C. grandifolium, C. javanicum, C. rhynchophyllum, C. sintoc), wounds (C. sintoc), joint or muscle pain (C. politum, C. subcuneatum), fever (C. subcuneatum), lethargy (C. javanicum), chest pain (C. javanicum) and as a postnatal tonic (C. paiei Kosterm.). The twig itself is used as charm to repel evil spirit (C. burmannii, $C$. subcuneatum), or fumes from it are used as a fumigant (C. racemosum). The fruits of $C$. lawang are used to make jewellery.

\section{KEY TO INDIVIDUAL OR GROUP OF SPECIES BASED ON STERILE MATERIAL}

Notes

1) These keys can be used to identify a few selected Cinnamomum species or group of species. In the latter case, in order to determine the final species identity, it is essential to compare the specimen at hand to the species descriptions or to reliably identified herbarium materials.

2) A key based on flowering material was not made, firstly because the number of anther locules, although useful for species identification when coupled with vegetative characters, is variable (see Table 1) and would result in a long key; and secondly, because floral characters such as stigma type, position of glands on filament and shape of staminode are not user friendly due to their minute size. Therefore, when a flowering specimen is available, I would advise the user to use the vegetative key to narrow down the species and then to use floral characters (by referring to Table 1 and the species descriptions) to finalise the species identity.

3) A hand lens is sometimes necessary when examining hair types particularly for the straight and appressed hairs which are usually minute and thin.

1. Leaves penninerved; terminal buds perulate. ........ .................... 17. C. porrectum

1. Leaves trinerved or triplinerved; terminal buds not perulate . . . . . . . . . . . . . . . 2

2. Leaves large, $25-48$ by $7.5-21 \mathrm{~cm} \ldots \ldots \ldots \ldots . .3$

2. Leaves small, (3-)5-25(-35) by (1-)3-7(-12) cm . . . 4

3. Leaves minutely appressed hairy below; major intercostal veins faint and less prominent than midrib 10. C. kerangas

3. Leaves glabrous below; major intercostal veins distinctly raised, as prominent as the midrib ... 7. C. grandifolium

4. Lateral veins extending to $1 / 2-3 / 4$ the length of leaf blade

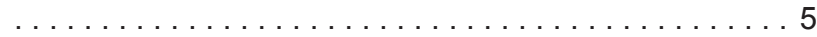

4. Lateral veins extending to the leaf tip or at least the base of acumen $\ldots \ldots \ldots \ldots \ldots \ldots \ldots \ldots \ldots \ldots \ldots$

5. Mature leaves blade with dense curly hairs below (if becoming glabrescent the remnant of indumentum always present near the midrib) . . . . . . . . . 11. C. kinabaluense

5. Mature leaves glabrous ............2. C. burmannii, 3. C. calciphilum, 20. C. sintoc, 26. C. verum

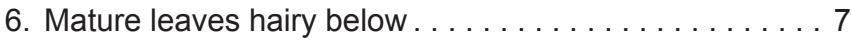

6. Mature leaves glabrous below . . . . . . . . . . 10

7. Mature leaves with straight and appressed hairs below, usually sparse . . . . . . . . . . . . . 8

7. Mature leaves with curly hairs below, usually dense (if becoming glabrescent the remnant of indumentum always present near the midrib) . . . . . . . . . . 9 
8. Midrib distinctly angular below; leaf apex caudate, acumen slender, 0.5-1.5(-2.5) cm long. . 19. C. rhynchophyllum

8. Midrib smoothly raised below; leaf apex when intact, acute or acuminate . . . . . 8. C. iners, 22. C. subavenium,

23. C. subcuneatum

9. Major intercostal veins scalariform and as prominent as the midrib; minor intercostal veins scalariform

9. C. javanicum

9. Major intercostal veins subscalariform, not as distinct as midrib; minor intercostal veins reticulate.

........ 1. C. angustitepalum, 22. C. subavenium,

23. C. subcuneatum, 24. C. sublanuginosum,

25. C. tahijanum

10. Leaf apex caudate, abruptly constricted, forming a slender and appendage-like acumen ...... 6. C. cuspidatum

10. Leaf apex acute or acuminate ........ 4. C. corneri, 5. C. crassinervium, 12. C. lawang, 13. C. paiei,

14. C. pendulum, 15. C. percoriaceum, 16. C. politum, 18. C. racemosum, 21. C. soegengii

\section{KEY TO SPECIES BASED ON FRUITING MATERIAL}

Note. The measurement of cupule height and diameter exclude perianth lobes.

1. Fruit perianth lobes entirely or partially persistent. . . . 2

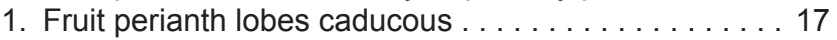

2. Fruit perianth lobes partially persistent, broken at upper half, leaving a truncate apex ............ 3

2. Fruit perianth lobes entirely persistent $\ldots \ldots \ldots \ldots 5$

3. Mature leaves with dense curly hairs below (if becoming glabrescent the remnant of indumentum always present near the midrib) . . . . . . . . . . 1. C. angustitepalum

3. Mature leaves glabrous . . . . . . . . . . . 4

4. Lateral veins extending to $1 / 2-3 / 4$ the length of leaf blade; twig-end with leaves opposite; cupule funnel-shaped, shallow, c. $2 \mathrm{~mm}$ high, c. $3 \mathrm{~mm}$ diam; infructescence paniculatecymose ... . . . . . . . . . . . . . 2. C. burmannii

4. Lateral veins extending to the leaf tip or at the base of acumen; twig-end with leaves spirally arranged; cupule cup-shaped, thick, 6-7 mm high, c. $4 \mathrm{~mm}$ diam; infructescence racemiform . . . . . . . . . . 18. C. racemosum

5. Fruit cupule enlarged, perianth lobes fleshy and thickly coriaceous, equal to or more than $0.5 \mathrm{~cm}$ long and partially covering the fruit $\ldots \ldots \ldots \ldots \ldots \ldots \ldots \ldots \ldots \ldots \ldots$

5. Fruit cupule not enlarged, perianth lobes small, less than $0.5 \mathrm{~cm}$ long and covering the base of fruit $\ldots \ldots \ldots 7$

6. Fruit perianth lobes plicate; fruit pedicel triangular in crosssection ................. 5. C. crassinervium

6. Fruit perianth lobes not plicate; fruit pedicel terete in crosssection . . . . . . . . . . . . . . . . 12. C. lawang

7. Mature leaves blade hairy below . . . . . . . . . 8

7. Mature leaves blade glabrous below . . . . . . . . . 14

8. Mature leaves with straight and appressed hairs below, usually sparse . . . . . . . . . . . . 9

8. Mature leaves with curly hairs below, usually dense (if becoming glabrescent the remnant of indumentum always present near the midrib) . . . . . . . . . . 12

9. Mature leaves equal or more than $25 \mathrm{~cm}$ long ........ ....................... . . kerangas

9. Mature leaves less than $25 \mathrm{~cm}$ long . . . . . . . 10

10. Midrib distinctly angular below; leaf apex caudate, abruptly constricted, forming a slender and appendage-like acumen ............... 19. C. rhynchophyllum

10. Midrib smoothly raised below; leaf apex when intact is acute, without acumen $\ldots \ldots \ldots \ldots \ldots \ldots$
11. Fruits cupule inconspicuous, very shallow, c. $1 \mathrm{~mm}$ high, c. $2 \mathrm{~mm}$ diam; leaf hair to $0.2 \mathrm{~mm}$ long, straight and appressed .................. . . iners

11. Fruits cupule distinct, c. $4 \mathrm{~mm}$ high, 4-6 mm diam; leaf hair $0.2-1 \mathrm{~mm}$ long, wavy or curly . 23. C. subcuneatum

12. Major intercostal veins scalariform and as prominent as the midrib; minor intercostal veins scalariform 9. C. javanicum

12. Major intercostal veins subscalariform, not as distinct as midrib; minor intercostal veins reticulate . . . . . . . 13

13. Leaf apex conspicuously acuminate, acumen $0.5-2 \mathrm{~cm}$ long; twig densely hairy, drying yellowish to greyish brown

25. C. tahijanum

13. Leaf apex if intact is acute; twig glabrous, drying dark brown to blackish . . . . . . . . . . . . 23. C. subcuneatum

14. Mature leaves more than $30 \mathrm{~cm}$ long . 7. C. grandifolium

14. Mature leaves less than $30 \mathrm{~cm}$ long . . . . . . . 15

15. Lateral veins extending to $2 / 3-3 / 4$ the length of leaf blade 26. C. verum

15. Lateral veins extending to the leaf tip or at least the base

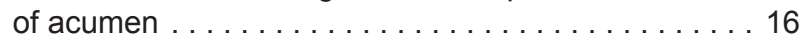

16. Leaf apex acuminate or acute with blunt tip, acumen to $1 \mathrm{~cm}$ long ..................... 16. C. politum

16. Leaf apex caudate, abruptly constricted, forming a slender and appendage-like acumen, $(0.5-) 1-3 \mathrm{~cm}$ long . . . . . .

.................... 6. C. cuspidatum

17. Leaves penninerved; terminal bud perulate ....................... 17. C. porrectum

17. Leaves trinerved or triplinerved; terminal bud not peru-

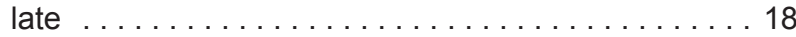

18. Lateral veins extending to $1 / 2-3 / 4$ the length of leaf blade

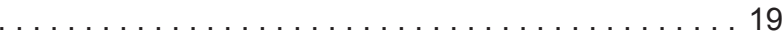

18. Lateral veins extending to the leaf tip or at the base of acumen ..................... 21

19. Mature leaves with dense curly hairs below (if becoming glabrescent the remnant of indumentum always present near the midrib) . . . . . . . . . 11. C. kinabaluense

19. Mature leaves glabrous . . . . . . . . . . . 20

20. Fruit cupule crateriform, shallow, 2-3 mm high, 5-6 mm diam. Habitat restricted to limestone .. . 3. C. calciphilum

20. Fruit cupule cup-shaped, deep, c. $6 \mathrm{~mm}$ high, $8 \mathrm{~mm}$ diam. Habitat not restricted to limestone . . . . . 20. C. sintoc

21. Mature leaves hairy below (if becoming glabrescent, the remnant of indumentum always present near the midrib)

21. Mature leaves glabrous $\ldots \ldots \ldots \ldots \ldots \ldots \ldots \ldots \ldots \ldots 23$

22. Fruit cupule cup-shaped, c. $4 \mathrm{~mm}$ high, c. $5 \mathrm{~mm}$ diam ..

24. C. sublanuginosum

22. Fruit cupule funnel-shaped, flattish, c. $1 \mathrm{~mm}$ high, c. $2 \mathrm{~mm}$ diam.................. 22. C. subavenium

23. Fruit cupule rim undulating, outer wall with faint longitudinal ridges................. 14. C. pendulum

23. Fruit cupule rim not undulating, outer wall smooth . . . 24

24. Fruit large, $1.5-2$ by $1 \mathrm{~cm}$; cupule large, $0.7-1 \mathrm{~cm}$ high, $1 \mathrm{~cm}$ diam. Large tree to $40 \mathrm{~m}$ tall . . . . 21. C. soegengii

24. Fruit small, $0.5-1$ by $0.3-0.5 \mathrm{~cm}$; cupule small, c. $5 \mathrm{~mm}$ high, $5-8 \mathrm{~mm}$ diam. Small to medium sized tree, to $12 \mathrm{~m}$ tall . . . . . . . . . . . . . . . . . . . . . 25

25. Twig and petiole upon drying pale brownish, concolorous with the leaf blade ................ 13. C. paiei

25. Twig and petiole upon drying black in colour, discolorous to the leaves blade . . . . . . . . . . . . . . 26

26. Minor intercostal veins prominent and distinctly raised. ... . . . . . . . . . . . . . . . 4. C. corneri 26. Minor intercostal veins faint.... . 15. C. percoriaceum 


\section{Cinnamomum angustitepalum Kosterm. - Map 1}

Cinnamomum angustitepalum Kosterm. (1969) 455; (1970b) 31; J.A.R.Anderson (1980) 222. - Type: Bojeng S 16242 (holo BO; iso K, L, SAN, SAR, SING), Borneo, Sarawak, Kuching district, Semengoh Forest Reserve. Cinnamomum turfosum Kosterm. (1969) 466, syn. nov. - Type: Kostermans 13075 A (holo BO; iso L), Kalimantan, West Kutei, Gunung Palimasen.

Medium sized tree to $18 \mathrm{~m}$ tall, to $30 \mathrm{~cm}$ diam. Bark smooth, slightly flaked or fissured, greyish brown; inner bark cream, reddish brown or pink, strongly scented with cinnamon smell; sapwood whitish. Twigs terete, apically angular, 2-3 mm diam, drying blackish to dark brown, hairy to glabrescent. Terminal buds not perulate, conical, c. $2 \mathrm{~mm}$ long, densely covered with curly hairs, pale brownish. Leaves opposite or subopposite, trinerved, coriaceous, covered with reddish brown curly hairs, if becoming glabrescent, remnant of indumentum always present on midrib below; blade ovate, ovate-elliptic or elliptic, (5-)6-10 by $3-5 \mathrm{~cm}$, without domatia, base cuneate, apex acuminate, acumen $0.5-1 \mathrm{~cm}$ long; midrib raised on both sides, c. $1 \mathrm{~mm}$ broad; lateral veins flat to impressed, making the leaf blade bullate, ending at base of acumen; major intercostal veins often not visible, if visible slender, subscalariform, 1-2 mm apart, less prominent than midrib; minor intercostal veins indistinct, reticulate; petiole stout, shallowly grooved above, hairy or glabrous, $1-1.5 \mathrm{~cm}$ long, c. $2 \mathrm{~mm}$ diam. Inflorescences axillary and/or subterminal, paniculate-cymose, with first and second order branching, 2-9 cm long; rachis c. $1 \mathrm{~mm}$ broad, greyish hairy. Flowers yellowish green when fresh, drying greyish hairy; pedicels 2-4 mm long; hypanthium c. $1 \mathrm{~mm}$ high; perianth lobes lanceolate, 4-5 mm long, hairy on both side, with abscission marking near the middle; fertile stamens $3-4 \mathrm{~mm}$ long, anthers 4-locular, oblong with truncate or obtuse tip, filaments $2 / 3$ the length of the stamen; glands stalked, attached at the base of third whorl filaments; staminodes 1.5-2 mm long, sagittate; ovary globose to subglobose, 1-2 mm across, stigma trilobed. Fruits subglobose, c. 7 by $6 \mathrm{~mm}$, orange when fresh, drying dark reddish; cupule shallow, c. $1 \mathrm{~mm}$ high, c. $2 \mathrm{~mm}$ diam, greyish hairy; perianth lobes partially persistent, broken at upper half leaving behind truncate apex, 1-2 mm long; pedicel stout, c. 1-2 mm long, c. $1 \mathrm{~mm}$ diam, appressed hairy.

Distribution - Endemic to Borneo: Sarawak (Bintulu and Kuching districts) and East Kalimantan.

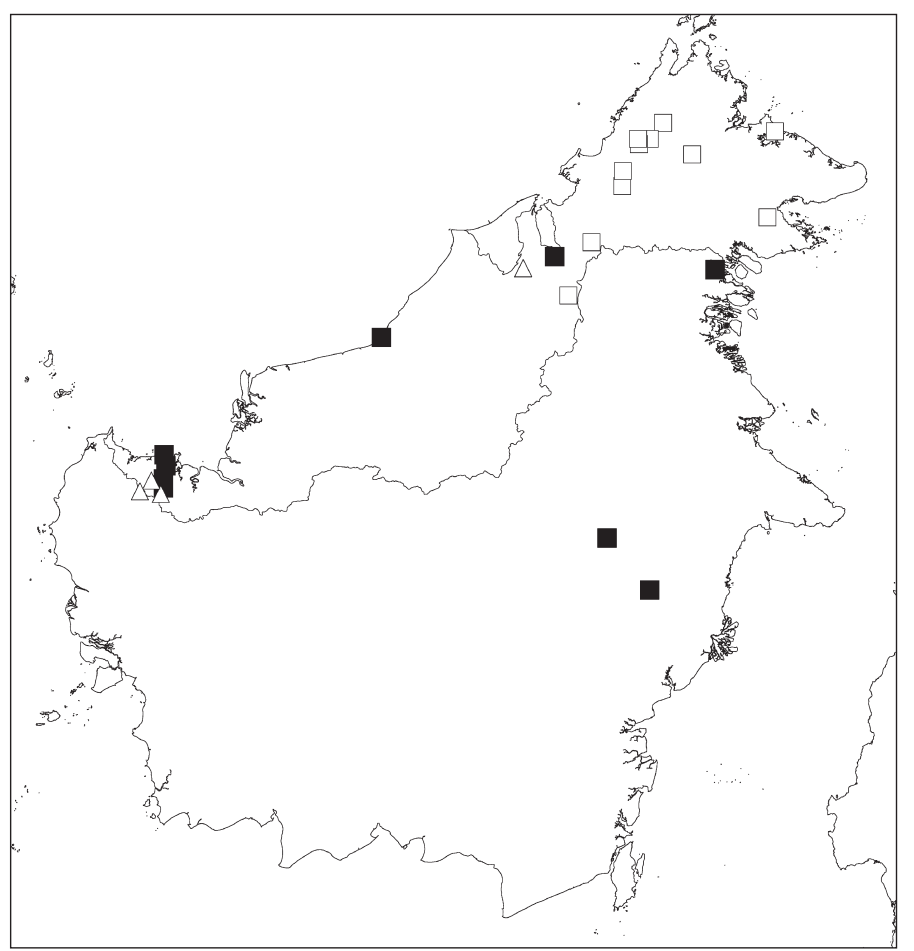

Habitat \& Ecology - In primary mixed dipterocarp and kerangas forest, on sandy soil with a little peat, at altitudes to $800 \mathrm{~m}$.

Vernacular names - Medang balong, Medang teja (both Malay).

Note - The fruit of the $C$. angustitepalum type specimen was overlooked by Kostermans (1969). After a close examination of the cited and newly identified specimens (BRUN 1899, CWL 1414, Hallier 2469, KEP 79313, Kostermans 12949, S 10593 and $S$ 37169), I am of the opinion that $C$. angustitepalum and C. turfosum are conspecific. Both of these species are similar in having reddish brown curly hairs, lateral veins extending to the base of acumen, inflorescence with short branches and lanceolate perianth lobes that are partially excised at fruiting stage. These characters also distinguish $C$. angustitepalum from the other Bornean Cinnamomum species.

\section{Cinnamomum burmannii (Nees \& T.Nees) Blume - Map 1}

Cinnamomum burmannii (Nees \& T.Nees) Blume (1826) 569; P.F.Burgess (1966) 332; Kosterm. (1986) 37; Coode et al. (1996) 151; Beaman et al. (2001) 398. - Laurus burmannii Nees \& T.Nees (1823) 57. - Cinnamomum kiamis Nees (1831) 75, nom. illeg. - Type: Blume s.n. (lecto L, barcode L0035722, here designated; iso L, barcode L0035724), West Java.

Cinnamomum chinense Blume (1826) 569. - Type: Blume s.n. (holo L, barcode L0035745), Java, introduced from China.

Laurus dulcis Roxb. [(1814) 30, nom. nud.] (1832) 303. - Persea dulcis (Roxb.) Spreng. (1825) 268. - Type: Roxburgh s.n. = Wallich Numer. List 2581 A (1831) (lecto K-W, here designated; iso BM, BR n.v., P).

Cinnnamomum mutabile Blume ex Miq. (1864) 264, syn. nov. - Type: Anon. s.n. (holo L, barcode L0035729), Java.

Cinnamomum mindanaense Elmer (1910) 705. - Type: Elmer 11105 (lecto $\mathrm{K}$, here designated; iso A n.v., L, NY, US), the Philippines, Mindanao.

Cinnamomum macrostemon Hayata (1913) 160, syn. nov. - Type: S.Nagasawa 155 (holo TI n.v.; iso K, L), Taiwan, Tainan, April 1910.

Cinnamomum hainanense Nakai (1939) 24. - Type: Lei 151 (holo TI n.v.; iso NY, US), Hainan, Ching Mai District, Kwei Shu, Pak Shik Ling and vicinity, 21 Oct 1932.

Tree to $20 \mathrm{~m}$ tall, $12-40 \mathrm{~cm}$ diam. Bark smooth, greyish brown; inner bark fragrant; sapwood yellowish. Twigs slender, terete, 2-3 mm diam, apically subangular, glabrous, dark brown to blackish. Terminal buds not perulate, conical, c. $2 \mathrm{~mm}$ long,
Map 1 Distribution of Cinnamomum angustitepalum Kosterm. (ם), C. burmannii (Nees \& T.Nees) Blume $(\square)$ and C. calciphilum Kosterm. $(\triangle)$. 
densely covered with straight appressed hairs. Leaves opposite or subopposite, pale greenish brown, triplinerved, chartaceous, glabrous below; blade not bullate, without domatia, lanceolate, (6-)8-12(-15) by $2-4.5 \mathrm{~cm}$, base cuneate, apex acute with blunt tip, tapering gradually, acumen indistinct; midrib raised on both sides, less than $1 \mathrm{~mm}$ broad; lateral veins raised on both sides, extending to about $2 / 3-3 / 4$ the length of blade; major intercostal veins slender, subscalariform, c. $2 \mathrm{~mm}$ apart, less prominent than midrib; minor intercostal veins faint, reticulate; petiole slender, distinctly grooved above, glabrous, $1-1.5 \mathrm{~cm}$ long, less than $1 \mathrm{~mm}$ diam. Inflorescences axillary or subterminal, slender, paniculate-cymose with first order branching, 2-12 cm long; rachis to $1 \mathrm{~mm}$ broad, minutely appressed hairy. Flowers minutely appressed hairy; pedicels slender, 3-5 mm long; hypanthium 1-1.5 mm high; perianth lobes oblanceolate, c. $5 \mathrm{~mm}$ long, appressed hairy on both sides; fertile stamens 3-3.5 mm long, anthers 4-locular, oblong with truncate apex, filaments c. $3 / 4$ the length of the stamen; glands shortly stalked or subsessile attached on each side at the middle or lower half of filaments; staminodes c. $1.5 \mathrm{~mm}$ long, sagittate; ovary ellipsoid, c. $1 \mathrm{~mm}$ across, stigma trilobed. Infructescences 4-8 $\mathrm{cm}$ long. Fruits ellipsoid or oblanceoloid with pointed tip, c. 10 by $5 \mathrm{~mm}$; cupule funnel-shaped, shallow, c. $2 \mathrm{~mm}$ high, c. $3 \mathrm{~mm}$ diam, glabrous; perianth lobes partially persistent, abscised at c. $1 / 3$ the length of the perianth lobes, leaving behind truncate apex, 1-1.5 mm long; pedicel, 5-8 $\mathrm{mm}$ long, c. $1 \mathrm{~mm}$ diam, glabrous.

Distribution - Sabah (Keningau, Lahad Datu, Ranau, Sandakan and Sipitang district) and Kalimantan. This species is widely distributed, occurring in Mauritius, Southern China, Indo-China, Sumatra, Java, Sulawesi and Nusa Tenggara, Hong Kong and Japan.

Habitat \& Ecology — In Borneo known mainly from secondary forest, villages and abandoned plantations at altitudes to $1500 \mathrm{~m}$. In Borneo this species is introduced and naturalised.

Uses - In Sabah, the bark is used for cooking, as a condiment and eaten fresh as snack. The leaves are used as tea (Christensen 376) and as a charm by the local people by hanging them on the wall in the house of the sick patient. (For more detail on general usage see Nguyên et al. 1999.)

Note - This species is easily discriminated by its glabrous leaf blades, lateral veins extending to about $2 / 3-3 / 4$ of the blade length and partially persistent perianth lobes on cupule.

\section{Cinnamomum calciphilum Kosterm. - Map 1}

Cinnamomum calciphilum Kosterm. (1969) 456; (1970b) 34; J.A.R.Anderson (1980) 222. - Type: Anderson S 15285 (holo BO; iso K, L, SAR, SING), Sarawak, Bau district, Gunung Staat.

Cinnamomum arbusculum Kosterm. (1970b) 31; J.A.R.Anderson (1980) 222, syn. nov. - Type: Anderson S 4726 (holo SAR; iso BO), Sarawak, Miri district, Gunung Mulu National Park, Gunung Api.

Small tree to $12 \mathrm{~m}$ tall, to $10 \mathrm{~cm}$ diam. Bark greyish brown. Twigs slender or stout, terete, 1-2 $\mathrm{mm}$ diam, apically subangular, minute straight appressed hairy when young, glabrescent, brownish to dark brown. Terminal buds not perulate, conical, 2-3 mm long, densely covered with straight appressed hairs. Leaves opposite or subopposite, pale yellowish brown, triplinerved or trinerved, coriaceous or thickly coriaceous, glabrous below; blade not bullate, without domatia, ovate, broadly ovate, oblong-elliptic or lanceolate, $(1.5-) 4-13$ by $(1.5-) 2-5(-6) \mathrm{cm}$, base rounded, cuneate, or cordate, apex acute with blunt tip; midrib flat above, smoothly raised below, to $1 \mathrm{~mm}$ broad; lateral veins flat above, smoothly raised below, extending to $2 / 3$ of blade length; major intercostal veins slender, subscalariform or reticulate, if subscalariform 2-4 mm apart, less prominent than midrib; minor intercostal veins indistinct, reticulate; petiole slender, flat above, sparsely minute-appressed hairy, 0.5-2.5 $\mathrm{cm}$ long, 1-2 mm diam. Inflorescences axillary and/or subterminal, slender, lax, paniculate-cymose with first order branching, 4-10 cm long; rachis to $1 \mathrm{~mm}$ broad, minutely hairy. Flowers drying greyish to reddish brown, appressed hairy; pedicels slender, 2-4 mm long; hypanthium c. $2 \mathrm{~mm}$ high; perianth lobes broadly ovate, c. $2 \mathrm{~mm}$ long, covered with curly hairs outside, straight appressed hairy inside; fertile stamens c. $2 \mathrm{~mm}$ long, anthers 4-locular, broadly ovoid, filaments c. 1/2 the length of the stamen; glands shortly stalked attached on each side at the middle of filaments; staminodes $1-1.5 \mathrm{~mm}$ long, sagittate; ovary subglobose, c. $2 \mathrm{~mm}$ across, stigma trilobed. Fruits ovoid, c. 1 by $0.5 \mathrm{~cm}$; cupule crateriform, shallow, 2-3 mm high, 5-6 $\mathrm{mm}$ diam, rim entire, undulating, minute-appressed hairy or glabrous; perianth lobes caducous; pedicel stout, 2-4 mm long, minute-appressed hairy or glabrous.

Distribution - Endemic to Borneo: known only from Sarawak (Bau, Kuching and Miri districts).

Habitat \& Ecology - Restricted to limestone hills where it is frequently found on peat soil at altitudes to $1300 \mathrm{~m}$.

Note - The type specimens of C. arbusculum and C. calciphilum can be differentiated on the basis of tree size (1 $\mathrm{m}$ tall vs 3-12 $\mathrm{m}$ tall), petiole length (stout, $5-8 \mathrm{~mm}$ long vs slender, $1-2 \mathrm{~cm}$ long), leaf texture (very rigidly coriaceous vs rigidly coriaceous), leaf size (2-5 by $3-7 \mathrm{~cm}$ vs $2-4$ by $4-12 \mathrm{~cm}$ ), leaf shape (ovate to ovate-suborbicular vs ovate-elliptical to lanceolate), leaf base (sub-cordate or rarely rounded vs shortly acute). However, after having re-examined the types and additional specimens, I find that both taxa cannot be maintained as different species. The differences seen in C. arbusculum and $C$. calciphilum measurement in height, petiole length and leaf blade strongly correlate with altitude, and. C. arbusculum may well be a dwarf form of $C$. calciphilum. Both species are restricted to limestone habitat but differ in that $C$. arbusculum is found in montane forest at altitudes to $1300 \mathrm{~m}$ and C. calciphilum in lowlands. Specimen S 37382 from lowland limestone is an intermediate form between the two species in having both types of leaf shape (ovate, elliptical and lanceolate) and base (rounded, acute and sub-cordate base). More importantly, the cupules of both species are of the same type in being small, with caducous perianth lobes and undulating rim. The venations of both species are similar in that the lateral veins extend $2 / 3$ of the blade length and the minor intercostal veins are densely and minutely reticulate. This agrees with Kostermans' observation on the lower leaf surfaces of $C$. calciphilum ("obscurely densely pitted") and C. arbusculum ("obscurely, minutely subareolatereticulate").

\section{Cinnamomum corneri Kosterm. - Map 2}

Cinnamomum corneri Kosterm. (1970b) 36; J.A.R.Anderson (1980) 223 ; Beaman et al. (2001) 398. - Type: Carson SAN 28012 (holo SING; iso BO, K, KEP, PNH, SAN, SAR), Sabah, Ranau district.

Small tree to $6 \mathrm{~m}$ tall, to $12 \mathrm{~cm}$ diam. Bark smooth, whitish brown to dark greyish brown; inner bark reddish to light brown; sapwood whitish or yellowish. Twigs terete, 2-3 mm diam, apically subangular, glabrous, drying blackish, discolorous to leaf blade. Terminal buds not perulate, conical, c. $2 \mathrm{~mm}$ long, densely covered with straight appressed hairs. Leaves opposite or subopposite, drying pale yellowish brown, trinerved or triplinerved, thinly coriaceous, glabrous below; blade not bullate, without domatia, ovate to lanceolate, $8-16$ by $3.5-6 \mathrm{~cm}$, base cuneate, apex acute with blunt tip; midrib raised on both sides, to $1 \mathrm{~mm}$ broad; lateral veins raised on both sides, extending to the tip of blade; major intercostal veins raised, slender, subscalariform, 2-4 mm apart, less prominent than midrib; minor intercostal veins distinctly raised, reticulate; petiole slender, flat 
above, glabrous, $0.7-1.5 \mathrm{~cm}$ long, c. $1 \mathrm{~mm}$ diam, drying blackish, discolorous to leaves blade. Inflorescences axillary, and/or subterminal, stout, paniculate-cymose with second or third order branching, 5.5-19 cm long; rachis c. $1 \mathrm{~mm}$ broad, appressed hairy. Flowers drying greyish appressed hairy; pedicels slender, 3-4 mm long; hypanthium 1-1.5 mm high; perianth lobes elliptic, 2-2.5 mm long, appressed hairy on both sides; fertile stamens 1.5-2 mm long, anthers ovoid with truncate or obtuse tip, anthers 2- or 4-locular, filaments $1 / 3-1 / 2$ the length of the stamen; glands sessile on each side at the middle of filaments; staminodes 1-1.5 mm long, sagittate; ovary oblong, 1-1.5 mm long, stigma trilobed. Fruits ellipsoid, c. 1 by $0.5 \mathrm{~cm}$; cupule funnel-shaped, c. $5 \mathrm{~mm}$ high, 5-6 mm diam, rim entire, not undulating, appressed hairy; perianth lobes caducous; pedicel stout, obconical, c. $4 \mathrm{~mm}$ long, apex c. $3 \mathrm{~mm}$ diam, tapering gradually to the base c. $1 \mathrm{~mm}$ diam.

Distribution - Endemic to Borneo: known only in Sabah (Ranau district).

Habitat \& Ecology — In primary mixed dipterocarp and lower montane forest at altitudes of 1200-1700 m.

Vernacular name - Kayu manis (Malay).

Note - Cinnamomum corneri resembles $C$. pendulum but differs in having a cupule that is deeply funnel-shaped with a smooth rim (vs shallow cup-shaped and rim undulating). Specimen S 22108 which was cited by Kostermans (1970b) as C. corneri belongs to $C$. pendulum.

\section{Cinnamomum crassinervium Miq. - Map 2}

Cinnamomum crassinervium Miq. (1864) 264; Merr. (1921) 272; Cammerl. (1925) 488; Masam. (1942) 308; Kosterm. (1970b) 37; J.A.R.Anderson (1980) 222. - Type: Mueller s.n. (holo L, barcode L0035758), Kalimantan.

Cinnamomum endlicheriicarpum Kosterm. (1969) 460; (1970b) 57, syn. nov. - Type: Sekalang BRUN 5285 (holo BO; iso K, KEP, L, SAR, SING), Brunei.

Tree to $25 \mathrm{~m}$ tall, to $16 \mathrm{~cm}$ diam. Bark whitish, greyish brown or dark brown; sapwood yellowish white. Twigs terete, 2-3 mm diam, apically angular, glabrous, yellowish brown. Terminal buds not perulate, conical, c. $4 \mathrm{~mm}$ long, glabrous. Leaves opposite or subopposite, trinerved or triplinerved, coriaceous to thinly coriaceous, glabrous below; blade not bullate, without domatia,

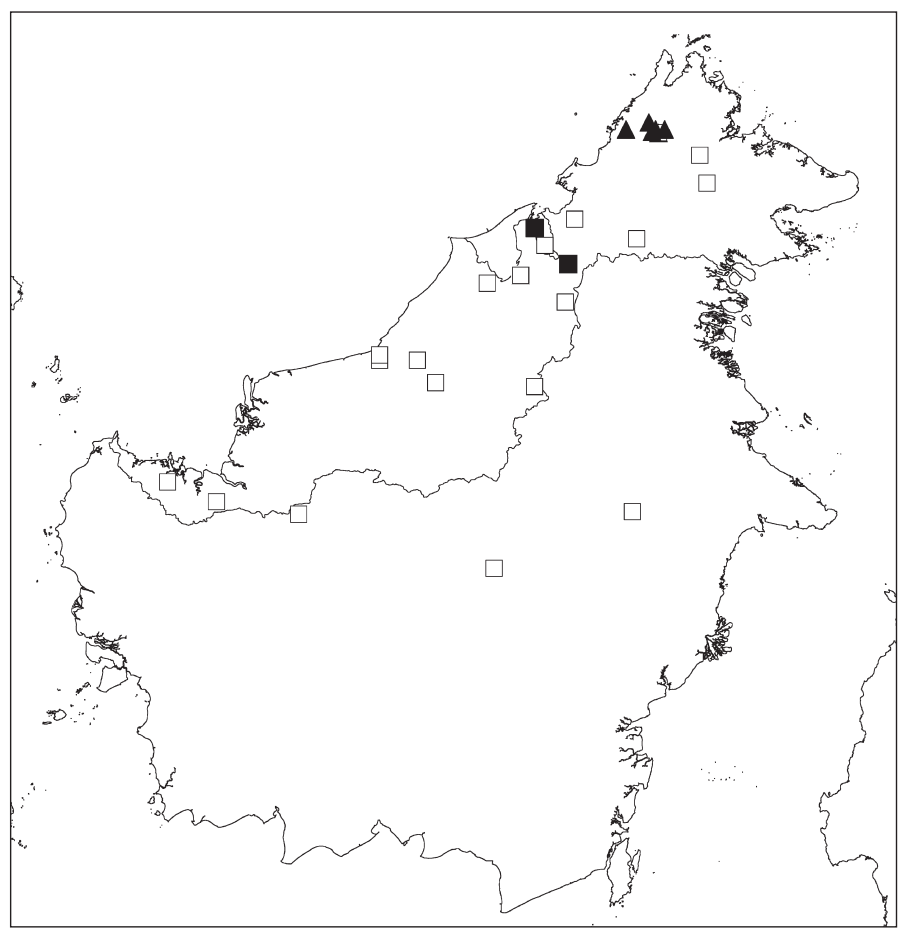

elliptic to narrowly elliptic, obovate, ovate, oblanceolate or lanceolate, $(7-) 13-22(-26)$ by $(2.5-) 3-7(-9) \mathrm{cm}$, base cuneate to rounded, apex acute or acuminate, acumen 1-2 cm long; midrib to $1 \mathrm{~mm}$ broad, raised on both surfaces; lateral veins distinctly raised on both sides, extending to the base of acumen; major intercostal veins 1-2 mm apart, obscure, slender, scalariform, less prominent than midrib; minor intercostal veins indistinct, reticulate; petiole, $(0.8-) 1-1.5 \mathrm{~cm}$ long, $1.5-2 \mathrm{~mm}$ diam, glabrous, grooved above. Inflorescences axillary, and/or subterminal, paniculate-cymose with second or third order of branching, c. $16 \mathrm{~cm}$ long; rachis c. $1 \mathrm{~mm}$ broad, appressed hairy. Flowers appressed hairy, yellowish when fresh; pedicels 3-6 mm long, c. $0.5 \mathrm{~mm}$ diam; hypanthium inconspicuous; perianth lobes elliptic, c. $2 \mathrm{~mm}$ long; fertile stamens c. $2 \mathrm{~mm}$ long, anthers of the first and second whorl of stamens 4-locular, those of the third whorl 2- or 4-locular, ovoid with truncate apex, filaments c. 1/2 the length of the stamen; glands sessile and attached at the base of filaments; staminodes c. $0.5 \mathrm{~mm}$ long, sagittate; ovary subglobose, to $1 \mathrm{~mm}$ across, stigma trilobed. Fruits oblong, c. 2 by $1 \mathrm{~cm}$, depressed at apex with pointed tip; cupule funnel-shaped, thick, $1 \mathrm{~cm}$ high, $1 \mathrm{~cm}$ diam, glabrous; perianth lobes persistent, oblong ovate, large, $1-1.5$ by $1-1.5$ $\mathrm{cm}$, plicate, thickly coriaceous, glabrous; pedicel obconical, triangular in cross-section, $0.5-1 \mathrm{~cm}$ long, apex to $0.5 \mathrm{~cm}$ diam, base c. $2 \mathrm{~mm}$ diam.

Distribution - Endemic to Borneo: Sabah (Kinabatangan, Labuk Sagut, Pensiangan and Ranau districts), Sarawak (Belaga, Bintulu, Kuching, Lawas, Lubok Antu, Marudi, Miri and Samarahan districts), Brunei and East Kalimantan.

Habitat \& Ecology — In mixed dipterocarp, kerangas, lower submontane forest and limestone forest at altitudes to $600 \mathrm{~m}$.

Vernacular names - Medang emparawas, Medang tiga, Medang tiga urat, Medang tija (all Malay), Wale (Murut).

Uses - In Borneo, a paste from crushed leaves and bark is applied to the forehead to treat headache. The root decoction is used for stomach ache.

Notes - 1. In 1969, Kostermans described C. endlicheriicarpum based on BRUN 5285. However, this specimen belongs to $C$. crassinervium because it shows the characteristics of C. crassinervium such as prominent midrib and lateral veins, glabrous blade and cupule that is deep and surrounded by enlarged and plicate perianth lobes. 
2. Kostermans (1970b) included BNBFD 3159 and S 27141 under $C$. pendulum but these two specimens in my opinion belong to $C$. crassinervium.

3. This species together with $C$. lawang are distinguished from other Cinnamomum species of Borneo by their enlarged fleshy cupule and perianth lobes. The continuous growth of perianth lobes in the fruiting stage is unusual in Cinnamomum, particularly in $C$. crassinervium where they become plicate and enlarged $(1-1.5$ by $1-1.5 \mathrm{~cm})$ to tightly fit on the cupule.

\section{Cinnamomum cuspidatum Miq. - Map 2}

Cinnamomum cuspidatum Miq. (1864) 262; Cammerl. (1925) 489; Kosterm. (1970b) 39; Kochummen (1989) 126; Kessler \& Sidiy. (1994) 155; Coode et al. (1996) 151. - Type: Korthals s.n. (lecto L, barcode L0035772, here designated; iso K, L, barcodes L0035768, L0035769, L0035770, L0035771, L0035773, L0035774; iso U, barcode U0002652), Sumatra.

Cinnamomum graciliflorum Gamble (1910) 218. - Type: Scortechini 1228 (lecto K, here designated; iso BM, E), Peninsular Malaysia, Perak, Gunung ljuk. - Syntype: Wray 3664 (K), Upper Perak.

Cinnamomum caudifolium Kosterm. (1969) 457; J.A.R.Anderson (1980) 222, syn. nov. - Type: Brunig S 1123 (holo BO; iso SAR), Brunei, Temburong, Pandaruan river.

Cinnamomum malayanum Kosterm. (1988) 444. — Type: Mohd. Shah 1575 (holo L; iso K, KEP, SING), Peninsular Malaysia, Pahang, Bukit Tenom, Ulu Keniyam.

Small tree to $7.5 \mathrm{~m}$ tall. Bark smooth, purplish brown; inner bark purplish brown; sapwood light pinkish brown. Twigs slender, 1-2 mm diam, apically terete, glabrous, drying light brown. Terminal buds not perulate, covered with straight appressed hairs. Leaves opposite or subopposite, trinerved, chartaceous to thinly coriaceous, glabrous below; blade not bullate, without domatia, rounded or elliptic, (5-)7-12(-15) by (2-)3-4(-5) $\mathrm{cm}$, base cuneate to narrowly cuneate, apex caudate, abruptly constricted, forming a slender and appendage-like acumen, (0.5-)1-3 cm long; midrib to $1 \mathrm{~mm}$ broad, raised or flat on both sides; lateral veins raised or flattened on both sides, extending to the base of acumen; major intercostal veins slender, 1-2(-5) $\mathrm{mm}$ apart, subscalariform, less prominent than midrib; minor intercostal veins indistinct, reticulate; petiole c. $1 \mathrm{~cm}$ long, c. $1 \mathrm{~mm}$ diam, glabrous, deeply grooved above. Inflorescences axillary and/or subterminal, paniculate-cymose with first order branching, 4-6 cm long; rachis 1-2 $\mathrm{mm}$ broad, appressed hairy. Flowers drying greyish, appressed hairy; pedicels $3-5 \mathrm{~mm}$ long; hypanthium c. $1 \mathrm{~mm}$ high; perianth lobes, ovate elliptic, c. $2 \mathrm{~mm}$ long, appressed hairy; fertile stamens 1-1.5 mm long; anthers 2- or 4-locular, ovoid to narrowly ovoid with rounded or obtuse tip, filaments c. 3/4 the length of the stamen, broad, transparent; glands sessile, attached at the middle of filaments; staminodes c. $1 \mathrm{~mm}$ long, sagittate; ovary subglobose, c. $1 \mathrm{~mm}$ across; stigma trilobed. Fruits broadly ellipsoid, $1-1.3$ by $1 \mathrm{~cm}$; cupule funnel-shaped, 3-5 mm high, 5-10 $\mathrm{mm}$ diam; perianth lobes persistent, hardened, triangular, c. $2 \mathrm{~mm}$ long, appressed hairy; pedicel obconical, thick, $5 \mathrm{~mm}$ long.

Distribution - Sarawak (Lawas and Miri districts) and Brunei. This species is also distributed in Sumatra, Java, Peninsular Malaysia.

Habitat \& Ecology — In mixed dipterocarp forest and kerangas forest at altitudes to $1000 \mathrm{~m}$.

Vernacular names - Medang lawang (Malay), Nyarung (Punan).

Note - Cinnamomum caudifolium from Borneo was distinguished on the basis of rounded or elliptic leaf shape ((5-)7-12 $(-15)$ by $(2-) 3-4(-5) \mathrm{cm})$, long acumen $((0.5-) 1-3 \mathrm{~cm})$ and 2-locular anthers, but $C$. malayanum and C. graciliflorum from Peninsular Malaysia and C. cuspidatum from Sumatra and Java have an elongate-elliptic leaf shape $(10-17$ by $3-4 \mathrm{~cm})$, short acumen $(0.5-2 \mathrm{~cm})$ and 2- or 4-locular anthers. Despite the variations in the leaves and anthers, I am of the opinion that C. caudifolium, C. graciliflorum and C. malayanum belong to C. cuspidatum because they share similar characters in having a funnel-shaped cupule with persistent hardened perianth lobes, slender and short (4-6 cm long) axillary or subterminal inflorescence with first order branching, glabrous leaf, distinctly grooved petiole and caudate leaf apex. The foregoing characters also distinguished $C$. cuspidatum from other Bornean species.

\section{Cinnamomum grandifolium Cammerl. - Map 3}

Cinnamomum grandifolium Cammerl. (1925) 477; Kosterm. (1964) 298. - Type: Jaheri 533 (holo BO; iso L), West Kalimantan, Sungai Bulu.

Treelet to $5 \mathrm{~m}$ tall. Bark smooth, greyish brown. Twigs stout, thick, terete, c. $5 \mathrm{~mm}$ diam, apically quadrangular, glabrous, dark brown. Terminal buds not perulate, glabrous, c. $5 \mathrm{~mm}$ long. Leaves opposite, triplinerved, coriaceous, glabrous below; blade without domatia, elliptic (young leaves) to oblong-elliptic (mature leaves), $35-48$ by $14-21 \mathrm{~cm}$, base cuneate, apex tapered, often gnawed; midrib glossy and prominently raised on both sides, 1-1.5 mm broad, lateral veins glossy and prominently raised on both sides, extending to the leaf apex, slightly looping and joining near margin; major intercostal veins distinctly raised below, glossy, as prominent as midrib, subscalariform, c. 5-15 mm apart; minor intercostal veins indistinct, reticulate; petioles stout $1-3 \mathrm{~cm}$ long, cylindrical, flattish or slightly grooved above. Inflorescences subterminal, stout, paniculate-cymose with second order branching, many-flowered, glabrous, c. 40 $\mathrm{cm}$ long; rachis c. $2 \mathrm{~mm}$ broad, glabrous. Flowers glabrous; pedicels $1-3 \mathrm{~mm}$ long; hypanthium to $0.5 \mathrm{~mm}$ high; perianth lobes coriaceous, ovate, c. $2 \mathrm{~mm}$ long, outer surface glabrous with fimbriate margins, inner surface covered with appressed hairs; fertile stamens c. $1.5 \mathrm{~mm}$ long, anthers 2-locular, oblong with truncate tip; staminodes c. $1 \mathrm{~mm}$ long, broadly hastate; glands reniform, attached to the middle of the filaments; ovary globose, c. $1 \mathrm{~mm}$ diam, stigma peltate. Fruits ellipsoid, c. 2 by $1 \mathrm{~cm}$; cupule funnel-shaped, deep, c. $7 \mathrm{~mm}$ high, c. $1 \mathrm{~cm}$ diam, glabrous; perianth lobes persistent, triangular, c. $2 \mathrm{~mm}$ high; pedicel c. $1 \mathrm{~cm}$ long, obconical, c. $5 \mathrm{~mm}$ diam at apex.

Distribution - Endemic to Borneo: Sarawak (Lawas and Marudi districts) and West Kalimantan.

Habitat \& Ecology — Lowland species.

Vernacular name - Temale (Murut).

Uses - A root decoction is used to treat stomach ache.

Note - This species which is collected from Lawas and Marudi districts ( $S 32789$ and S 91386) is a new record for Sarawak. It is a remarkable species with enormous leaves and is often confused with another large leaf species, C. kerangas. However, C. grandifolium differs from $C$. kerangas in having 2-locular anthers (vs 4-locular), glabrous leaf (vs sparsely and minutely hairy), distinctly raised and glossy intercostal veins (vs faint) and funnel-shaped cupule (vs cup-shaped).

\section{Cinnamomum iners Reinw. ex Blume - Map 3}

Cinnamomum iners Reinw. ex Blume (1826) 570; Merr. (1921) 273; Cammerl. (1925) 471; Merr. (1929) 77; Masam. (1942) 309; F.G.Browne (1955) 215; J.A.R.Anderson (1980) 223; Coode et al. (1996) 151; Argent et al. (1997) 310. - Cinnamomum nitidum Hook. var. iners Miq. (1864) 258. - Type: Reinwardt s.n. (holo L, barcode L0035811), Java.

Cinnamomum eucalyptoides Nees (1831) 73. - Type: Wallich Numer. List 2582C (lecto K-W, here designated), Hortus Botanicus Calcuttensis. - Syntype: Wallich Numer. List 2583B (K-W), Hortus Botanicus Calcuttensis.

Cinnamomum neglectum Blume (1836) 38. - Cinnamomum javanicum Blume var. neglectum Meisn. (1864) 10. - Type: Kuhl \& v. Hasselt s.n. (holo L, barcode L0035821), Java, Mt Kaputiang.

Cinnamomum nitidum Hook. var. spurium Blume (1836) 39, t. 6, f. 1. - Type: Blume s.n. (holo L, barcode L0035822), West Java, Tjiawi. 
Cinnamomum nitidum Hook. var. subcuneatum Blume (1836) 40, t. 13, f. 2. - Type: Blume s.n. (holo L, barcode L0035823), Java.

Cinnamomum iners Reinw. ex Blume var. latum Blume (1836) 42, t. 18.

- Type: Spanoghe s.n. (holo L, barcode L0035813), Sumatra, Bantam.

Cinnamomum pseudosintok Miq. (1858) 902. - Type: Junghuhn s.n. (K, U n.v.), Java, Preanger.

Cinnamomum calyculatum Miq. (1860) 358. - Type: Teijsmann s.n. (holo L, barcode L0035815), Sumatra.

Cinnamomum laxiflorum Meisn. (1864) 21. - Type: de Vriese s.n. (holo K, barcode K000227502), Java.

Cinnamomum dasyanthum Miq. (1864) 259. - Type: Korthals s.n. (lecto L, barcode L0035818, here designated; iso L, barcodes L0035816, L0035817, L0035819), Sumatra.

Cinnamomum iners Reinw. ex Blume var. angustifolium Ridl. (1924) 93. - Type: Ridley 14516 (lecto SING, here designated), Temengoh, Perak, Peninsular Malaysia 1909. - Syntype: Ridley s.n. (SING), Peninsular Malaysia, Kelantan, Chaning river bank, Feb. 1917.

Possible synonyms (see note 1 ):

Cinnamomum nitidum Hook. (1827) 176. - Type: not designated (possibly described from living cultivated plant).

Laurus nitida Roxb. [(1814) 30] (1832) 300. - Cinnamomum nitidum (Roxb.) Nees (1831) 73, non Hook., nom. illeg. - Type: Roxburgh s.n. (n.v.), cultivated in Hortus Botanicus Calcuttensis, from Sumatra.

Cinnamomum nitidum Hook. var. oblongifolia Blume (1834) 64. - Type: Blume s.n. (L, not found), Java.

Cinnamomum nitidum Hook. forma angustifolia Miq. (1864) 258. - Type: Zollinger 3589 ( $L$, not found).

Cinnamomum nitidum Hook. forma borneensis Miq. (1864) 258. - Type: Korthals s.n. (L, not found), Borneo.

Tree or small tree 4-12 m tall, c. $14 \mathrm{~cm}$ diam. Bark smooth; inner bark yellowish. Twigs stout or slender, terete, $2-3 \mathrm{~mm}$ diam, apically terete to subangular, drying dark brown to black. Terminal buds not perulate, conical, 2-4 mm long, densely covered with straight appressed hairs. Leaves opposite to subopposite, drying pale green, trinerved, coriaceous, shiny and hairy above, hairy below, the hairs sparsely distributed, minute, short (to c. $0.2 \mathrm{~mm}$ ), appressed and straight; blade not bullate, without domatia, ovate, oblong-elliptic to lanceolate, $8-12$ by $4-7 \mathrm{~cm}$, base rounded to cuneate, apex acute, tip often gnawed; midrib smoothly raised on both sides, to $1 \mathrm{~mm}$ broad; lateral veins raised on both sides, extending to the leaf tip; major intercostal veins raised, slender, subscalariform, 2-5 mm apart; minor intercostal veins faint, reticulate; petiole stout, subterete, shallowly grooved above, glabrescent, c. $0.5 \mathrm{~cm}$ long, $1-2 \mathrm{~mm}$ diam. Inflorescences axillary or subterminal, slender, drying

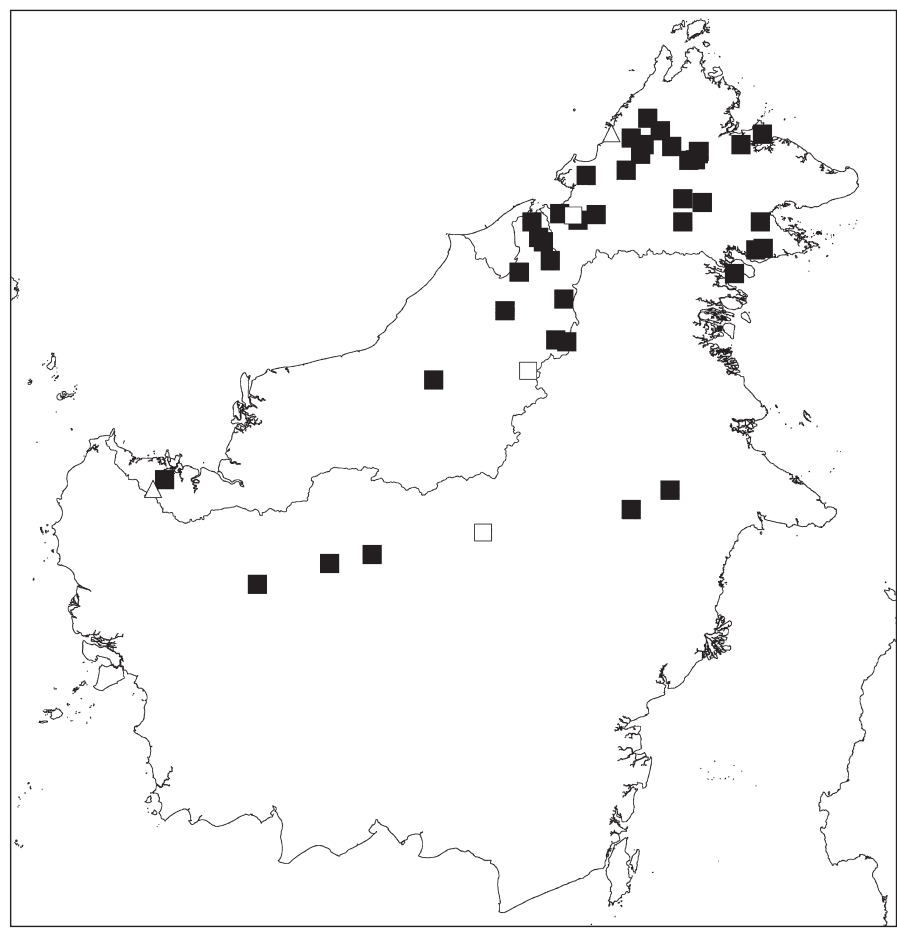

blackish, paniculate-cymose with up to third order branching, up to $16 \mathrm{~cm}$ long; rachis angular, 1-2 $\mathrm{mm}$ broad, densely to sparsely covered with short straight appressed hairs; bracts caducous. Flowers hairy, drying silky and greyish; pedicels slender, 3-5 mm long; hypanthium 1-3 $\mathrm{mm}$ high; perianth lobes elliptic, c. $1.5-2.5 \mathrm{~mm}$ long, appressed pilose on both side; fertile stamen 1.5-2.5 mm long, anthers oblong ovate with truncate or obtuse tip; that of first and second whorl 4-locular, of third whorl 2- or 4-locular; filament 2/3-3/4 the length of the stamen; glands stalked on each side at the lower half of filaments; staminodes $1-1.5 \mathrm{~mm}$ long, apex hastate; ovary subglobose, 1-1.5 mm long, stigma trilobed. Infructescences $8-12 \mathrm{~cm}$ long. Fruits ellipsoid or obovoid with pointed tip, c. 10 by $8 \mathrm{~mm}$; cupule inconspicuous, very shallow, $1 \mathrm{~mm}$ high, $2 \mathrm{~mm}$ diam, appressed hairy; perianth lobes persistent, elliptic or ovate, 2 by $1-2 \mathrm{~mm}$; pedicel slender, $3-4 \mathrm{~mm}$ long, c. $1 \mathrm{~mm}$ diam, minute-appressed hairy.

Distribution - Sarawak (Kuching district) and Sabah (Kota Kinabalu district). This species is widely distributed in Southeast Asia in Indochina, Sumatra, Peninsular Malaysia, Java and the Philippines.

Habitat \& Ecology — In Borneo possibly naturalised, along roadsides and frequently found in open areas and secondary forest.

Vernacular names - Medang teja (Malay).

Uses - In Borneo, this species is planted as landscape trees. For more detail on general usage see Ibrahim et al. 1995.

Notes - 1. Cinnamomum nitidum and its infraspecific taxa that were described from the Malesian region have been associated with C. iners by Blume (1836) and Cammerloher (1925), and in my opinion possibly belong here. The types need to be located and identified in order to determine their correct status. I did not have the opportunity to look for any possible type of Laurus nitida. The plate of Laurus nitida in Roxburgh's Flora Indica (1832) is not informative enough to confirm the species identity. I was not able to locate the infraspecific types of $C$. nitidum in L.

2. Cinnamomum iners in Borneo and Peninsular Malaysia is probably naturalised since plants are frequently found along roadside and in secondary forest. In Java, where it grows naturally in forest, the fruit cupule is considerably larger than the Bornean and Peninsular Malaysian specimens (4-5 mm high, 4-6 $\mathrm{mm}$ diam vs $1 \mathrm{~mm}$ high, $2 \mathrm{~mm}$ diam). 


\section{Cinnamomum javanicum Blume - Map 3}

Cinnamomum javanicum Blume (1826) 570; Merr. (1921) 272; Masam. (1942) 309; Kosterm. (1970b) 47; J.A.R.Anderson (1980) 223; Coode et al. (1996) 151; Argent et al. (1997) 310. — Type: Blume s.n. (lecto L, barcode L0035826, here designated), West Java, Bantam, Harriang.

Laurus pseudocassia Reinw. ex Blume (1823) 67, nom. nud. - Representative specimen: Blume 1440 (L, barcode L0035825), Java.

Melastoma reinwardtianum Blume (1826) 1069. - Type: Reinwardt s.n. (holo L, barcode L0035833), Java.

Cinnamomum sulphuratum Nees var. $\beta$ Miq. (1858) 891. - Type: Blume s.n. (holo L, barcode L0035827), Java.

Medium-sized to large tree to $35 \mathrm{~m}$ tall, to $35 \mathrm{~cm}$ diam. Bark smooth or lenticellate, whitish or greyish; inner bark fibrous, yellowish, brownish, reddish brown or orange; sapwood yellowish white. Twigs stout, terete to subangular, $2-5 \mathrm{~mm}$ diam, apically angular, densely hairy, glabrescent, yellowish brown to dark brown. Terminal buds not perulate, conical or ellipsoid, c. 3-5 $\mathrm{mm}$ long, densely covered with curly hairs. Leaves opposite or subopposite, trinerved, thinly coriaceous to coriaceous, densely covered with curly hairy below, sometimes glabrescent, if so remnant of indumentum always present near midrib below; without domatia, elliptic to oblong elliptic, $12-25(-35)$ by $5-12 \mathrm{~cm}$, base cuneate to slightly rounded, apex acuminate to mucronate with pointed or blunt tip, acumen $0.5-2 \mathrm{~cm}$ long; midrib raised and prominent on both sides, angular below, c. $1 \mathrm{~mm}$ wide; lateral veins raised and prominent on both sides, extending to the base of acumen or leaf tip; major intercostal veins impressed above, making the blade bullate, prominently raised below, usually as distinct as midrib, scalariform, 2-(5-10) mm apart; minor intercostal veins distinct and raised, scalariform; petiole stout, terete, hairy or glabrescent, 1-2 cm long, 1-4 mm diam. Inflorescences subterminal, paniculate-cymose with second or third order of branching, (5-)13-25 cm long, densely hairy, yellowish brown; rachis stout, 1-4 mm broad; bracts occasionally persistent, if persistent, elliptic, c. 3-8 mm long. Flowers drying yellowish hairy; pedicels stout, $2-3(-5) \mathrm{mm}$ long, c. 1 $\mathrm{mm}$ diam; hypanthium c. $1 \mathrm{~mm}$ high; perianth lobes elliptic to broadly elliptic, densely hairy, (1.5-)2-2.5(-3.5) mm long; fertile stamens 2-2.5 mm long, anthers 2- or 4-locular, ovoid with obtuse or truncate tip, filaments c. 1/3-1/2 the length of the stamen; glands large, sessile to shortly stalked, attached at the middle or base of filaments; staminodes 1-2 mm long, hastate; ovary ovoid or subglobose, c. $1 \mathrm{~mm}$ across, stigma subpeltate. Fruits ellipsoid with acute tip, c. 1 by $0.8 \mathrm{~cm}$; cupule cup-shaped, 2-4 mm high, c. $8 \mathrm{~mm}$ diam, hairy; perianth lobes persistent, broadly ovate, $3-5$ by $2-4 \mathrm{~mm}$, hairy; pedicels $4-5$ $\mathrm{mm}$ long, 1-2 $\mathrm{mm}$ diam.

Distribution - Sarawak (Belaga, Kuching, Lawas, Limbang, Marudi and Miri districts), Sabah (Beaufort, Keningau, Kinabatangan, Labuk Sugut, Lahad Datu, Ranau, Sandakan, Sipitang, Tambunan, Tawau, Tenom and Tuaran districts), Brunei, and East and West Kalimantan. This species is also distributed in Sumatra, Java and Peninsular Malaysia.

Habitat \& Ecology — In primary kerangas, mixed dipterocarp and submontane forests at 300-1300 m altitudes.

Vernacularnames - Daun buluh (Malay), Gerung, Kayu lekua (both Kelabit), Medang (Iban).

Uses - The wood is used for house building. The plant is used medicinally with Kadsura scandens Blume to treat stomach ache and to initiate abortion (S 57064 and Christensen 252). The fume from burnt roots is used to repel evil spirits from the body (S 57046). The root decoction is drunk to treat fatigue and chest pain (Christensen 350).

Notes - 1. Blume (1826) in his original description did not indicate any specimen, but later (Blume 1836) he enumerated specimens collected by him from Harriang in Bantam, Preanger in West Java and Mt Burangrang in Krawang, and one specimen from Sumatra collected by Praetorius. The designated lectotype from Harriang is the only specimen that can be found in $L$ while the rest cannot be confidently identified due to scanty labels.

2. Cinnamomum javanicum is easily recognised by its dense curly hairs on the lower leaf surface, prominent scalariform major and minor intercostal veins and bullate leaf blade. Kostermans (1970b) misidentified specimen SAN 16268 and SAN 21007 as $C$. bintuluense (synonym of $C$. tahijanum) which in my opinion belong to $C$. javanicum.

3. The leaves of $C$. javanicum are very variable in texture, size and venation. The lowland $C$. javanicum populations have stout vegetative and reproductive structures, strongly bullate leaves and prominent major intercostal veins. Those found at higher elevation in extreme conditions such as ultramafic soil, kerangas forest and montane forest have slender vegetative and reproductive structure, less bullate leaves and less prominent major intercostal veins.

\section{Cinnamomum kerangas Kosterm. - Map 4}

Cinnamomum kerangas Kosterm. (1970b) 47; F.G.Browne (1955) 215; J.A.R.Anderson (1980) 223. - Type: Caroll S 2288 (holo SING; iso BM, KEP, SAN, SAR), Sarawak, Kuching district, Setapok Forest Reserve.

Small tree or shrub 6-11 m tall, 6-15 cm diam. Bark smooth, greyish brown, scented; inner bark fairly hard, brown; sapwood yellowish. Twigs distinctly quadrangular, $3-5 \mathrm{~mm}$ diam, minute-appressed hairy, yellowish brown to dark brown. Terminal buds not perulate, greyish, c. $6 \mathrm{~mm}$ long, densely covered with straight appressed hairs. Leaves opposite or subopposite, scented, trinerved, coriaceous, below sparsely and minutely covered with straight appressed hairy; blade without domatia, ovate-oblong to lanceolate, $25-45$ by $7.5-12$ $\mathrm{cm}$, base cuneate, apex often gnawed; midrib and lateral veins prominently raised on both sides; lateral veins extending to the leaf tip; major intercostal veins faint, slender, scalariform to subscalariform, 2-4 $\mathrm{mm}$ apart, less prominent than midrib; minor intercostal veins indistinct; petiole stout, distinctly quadrangular, minute-appressed hairy, brown to dark brown, $1-2.5 \mathrm{~cm}$ long, 3-4 mm diam. Inflorescences subterminal, lax, paniculatecymose with second and third order branching, 22-27 cm long, many-flowered; rachis c. $1 \mathrm{~mm}$ broad, appressed hairy. Flowers drying greyish appressed hairy; pedicels slender, 2-7 $\mathrm{mm}$ long; hypanthium c. $1 \mathrm{~mm}$ high; perianth lobes elliptic to oblong or obovate, densely hairy, c. $4 \mathrm{~mm}$ long; fertile stamens 2.5-3 mm long, anthers 4-locular, filaments slender, c. 2/3 the length of the stamen; glands attached at the middle of filaments; staminodes c. $2 \mathrm{~mm}$ long, sagittate; ovary subglobose, c. 2 $\mathrm{mm}$ across, stigma subpeltate. Fruits ellipsoid, c. 1 by $0.5 \mathrm{~cm}$; cupule indistinct, consisting of persistent perianth lobes; perianth lobes appressed hairy, elliptic, c. 2 by $1 \mathrm{~mm}$, upon drying recurved.

Distribution - Endemic to Borneo: Sarawak (Kuching district) and West Kalimantan.

Habitat \& Ecology - Peat swamp and kerangas forest on podsol soils, at altitudes to $30 \mathrm{~m}$.

Vernacular name - Medang tija, Tija kerangas (both Malay).

Note - In Sarawak, this species is known only from Setapok Forest Reserve, Kuching district. Browne (1955) recognised the species under the vernacular name 'Tija kerangas (Cinnamomum sp.)' and noted in general that the species is fairly common in certain part of Sarawak. More field collection and observation are needed to confirm this. In Kalimantan, this species is represented by only one collection from Pangkalan Batu, Singkawang. 


\section{Cinnamomum kinabaluense Heine - Map 4}

Cinnamomum kinabaluense Heine (1953) 213; Kosterm. (1964) 310; Beaman et al. (2001) 399. - Type: Clemens 32690 (holo M n.v.; iso BM, BO, K, L, NY), Sabah, Ranau District, Gunung Kinabalu, Gunung Nunkok.

Small tree or shrub 2-3 $\mathrm{m}$ tall. Twigs terete, 2-4 mm diam, apically angular, densely hairy or glabrescent, brown. Terminal buds not perulate, conical, c. $5 \mathrm{~mm}$ long, densely covered with curly hairs. Leaves opposite or subopposite, triplinerved, coriaceous, densely covered with curly hairs or if becoming glabrescent, the remnant of indumentums always present near the midrib, indumentum drying yellowish; blade bullate in between midrib and lateral veins, without domatia, ovate elliptic to orbicular, (3-)5-7.5(-9) by (2-)3-5(-6) $\mathrm{cm}$, base usually rounded, rarely cuneate, apex acute to acuminate or obtuse, acumen $0.2-0.5 \mathrm{~mm}$ long; midrib prominent and raised on both sides; lateral veins prominent and raised on both sides, extending to c. 3/4 the length of the blade; major intercostal veins faint, subscalariform, 3-8 $\mathrm{mm}$ apart; minor intercostal veins faint, reticulate; petiole (5-)8-10 $\mathrm{mm}$ long, $1-3 \mathrm{~mm}$ thick, flat above, widening at base of lamina, initially hairy then glabrescent. Inflorescences axillary and/or subterminal, paniculate-cymose with first or second order branching, 3-10 cm long, brownish hairy, few-flowered, branches $0.5-1 \mathrm{~cm}$ long, with 3-6 flowers clustered at the tips. Flowers greyish; perianth lobes oblong to oblong obovate, densely appressed hairy, 2-3 mm long; fertile stamens 1-2 mm long, anthers 2-locular, filaments c. 1/2 the length of the stamen; glands adnate at the middle part of filaments; staminodes 1.5-2 mm long, sagittate; ovary subglobose c. $1 \mathrm{~mm}$ long, ovary and style appressed hairy, stigma trilobed. Fruits globose, c. 5 by $5 \mathrm{~mm}$; cupule shape, thick, c. $3 \mathrm{~mm}$ high, 5-6 $\mathrm{mm}$ diam, rim entire, undulating; perianth lobes caducous; pedicels c. $5 \mathrm{~mm}$, obconical, hairy.

Distribution - Endemic to Borneo: Sabah (Ranau and Tambunan districts) and Sarawak (Julau district).

Habitat \& Ecology — In submontane forest at altitudes above $1200 \mathrm{~m}$.

Note - This species is a new record for Sarawak collected from Julau district (S 50966). Previously, it was only known from Ranau district, Sabah. Cinnamomum kinabaluense re-

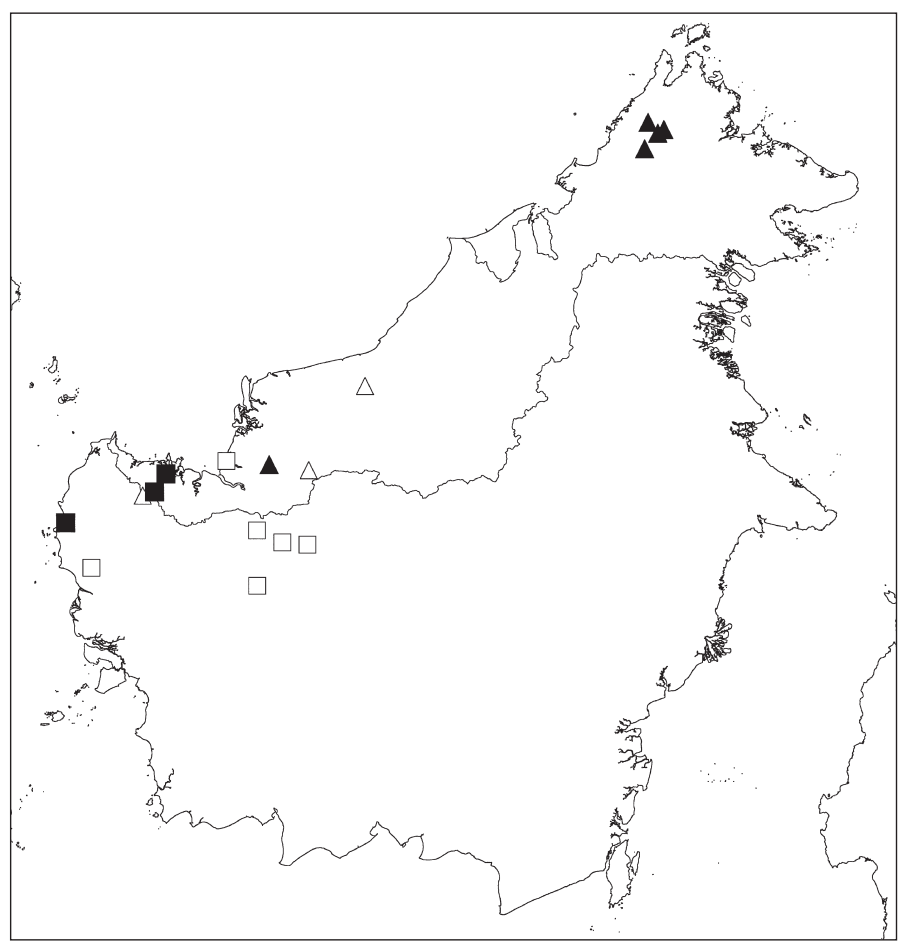

sembles $C$. angustitepalum but differs by having a cupule with caducous perianth lobes (vs persistent), indumentum yellowish upon drying (vs reddish upon drying) and 2-locular anthers (vs 4-locular).

\section{Cinnamomum lawang Kosterm. - Map 4}

Cinnamomum lawang Kosterm. (1970b) 50, excl. specim. bb 29036. — Type: Budding bb 28100 (lecto BO, here designated; iso L, SING), West Kalimantan, Melawi, Betoeng, Tengkoejoeng, alt. 450 m, 24 Nov. 1939. - Syntypes: Budding bb 28100 (BO, L), West Kalimantan, Tjatit, 11 May 1939; bb 24534 (BO, L), West Kalimantan, Lamas.

Tree to $27 \mathrm{~m}$ tall, to $72 \mathrm{~cm}$ diam. Twigs apically distinctly quadrangular, stout, glabrous, $2-3 \mathrm{~mm}$ diam. Terminal buds not perulate, conical, 5-7 mm long, densely covered with straight appressed hairs. Leaves opposite or subopposite, trinerved, chartaceous to thickly coriaceous, glabrous below, or young leaves covered with straight appressed hairs but soon becoming glabrescent; blade not bullate, without domatia, elliptic to broadly elliptic, $10-20$ by $4.5-8.5 \mathrm{~cm}$, base cuneate, apex acute; midrib raised on both sides, to $1 \mathrm{~mm}$ broad; lateral veins raised on both sides, extending to the leaf tip; major intercostal veins slender, scalariform, $2-3 \mathrm{~mm}$ apart, less prominent than midrib; minor intercostal veins indistinct, reticulate; petioles stout, flat or shallowly grooved above, $1.5-2 \mathrm{~cm}$ long, c. $2 \mathrm{~mm}$ diam. Inflorescences terminal, paniculate-cymose with second order branching, c. $12 \mathrm{~cm}$ long, densely brownish hairy; rachis 1-1.5 mm broad. Flowers (immature) brownish hairy; pedicel rather thick, obconical, c. $3 \mathrm{~mm}$ long, c. $1 \mathrm{~mm}$ diam; hypanthium c. $1 \mathrm{~mm}$ long; perianth lobes (immature) coriaceous, ovate, 2-3 mm long; fertile stamens c. $2 \mathrm{~mm}$ long, anthers 4-locular, ovoid, filaments c. 1/2 the length of the stamen; glands sessile, attached at the base of filaments; staminodes c. $1 \mathrm{~mm}$ long, sagittate; ovary subglobose, c. $1 \mathrm{~mm}$ across, stigma peltate. Fruits ellipsoid, to 1.5 by $1 \mathrm{~cm}$; cupule funnel-shaped, thick, $0.8 \mathrm{~cm}$ high, $1 \mathrm{~cm}$ diam, hairy; perianth lobes persistent, ovate, large, $5-7$ by $5 \mathrm{~mm}$, not plicate, thickly coriaceous; pedicel obconical, short, terete in cross-section, c. $1.5 \mathrm{~cm}$ long, $1-2 \mathrm{~mm}$ diam.

Distribution - Endemic to Borneo: Sarawak (Sri Aman district) and West Kalimantan. 
Habitat \& Ecology — In lowland forest.

Vernacular names - Balong, Lawang (both Malay).

Uses - The fruits are highly esteemed by Dayak women for perfumery. Information extracted from herbarium label (Hewitt s.n.) indicated that the fruits are used for bead in jewellery in Sri Aman district, Saribas, Sarawak.

Notes - 1. This species is a new record for Sarawak collected from Sri Aman district (Hewitt s.n., Aug 1908). It shares with $C$. crassinervium the same type of enlarged fleshy fruit cupule but differs in having distinctly stout and quadrangular apical twigs (vs less angular), 4-locular stamens (vs 2-locular), cupule perianth lobes not plicate (vs plicate) and fruit pedicel terete in cross-section (vs triangular).

2. In the protologue, Kostermans (1970b) cited two different specimens collected from Tengkoejoeng on 24 Nov. 1939 and Tjatit on 11 May 1939 but both bearing the same collection number $b b$ 28100. In this paper, the specimen $b b 28100$ from Tengkoejoeng is designated as the lectotype.

\section{Cinnamomum paiei Kosterm. - Map 4}

Cinnamomum paiei Kosterm. (1988) 448. - Type: Ilias \& Mamit S 29332 (holo L; iso BO, SAN, SAR, SING), Sarawak, Bau district, Bungo Range.

Tree to $12 \mathrm{~m}$ tall, $20 \mathrm{~cm}$ diam. Twigs slender, terete, c. $3 \mathrm{~mm}$ diam, apically angular, glabrous, brown, concolorous with leaf blade. Terminal buds not perulate, conical, c. 2 mm long, densely covered with straight appressed hairs. Leaves opposite to subopposite, pale greenish brown, trinerved, coriaceous, glabrous, young leaves covered with straight appressed hairs and becoming glabrescent with the remnant of indumentum always present at midrib of mature leaves; blade not bullate, without domatia, oblong-ovate, $12-20$ by $3.5-7 \mathrm{~cm}$, base cuneate, apex acute, often gnawed; midrib raised on both sides, c. $1 \mathrm{~mm}$ broad; lateral veins raised on both sides, extending to the leaf tip; major intercostal veins slender, scalariform to subscalariform, 2-3 mm apart, less prominent than midrib; minor intercostal veins faint, reticulate; petiole stout, flat above, 0.5-1 $\mathrm{cm}$ long, $2 \mathrm{~mm}$ diam, drying brownish, concolorous with leaf blade. Inflorescences unknown. Infructescences terminal, stout, paniculate-cymose with third order branching, c. $20 \mathrm{~cm}$ long; rachis c. $2 \mathrm{~mm}$ broad, appressed hairy. Fruits ellipsoid, c. 1 by $0.5 \mathrm{~cm}$; cupule cup-shaped, deep, c. $5 \mathrm{~mm}$ high, c. $8 \mathrm{~mm}$ diam, rim entire, not undulating glabrous, outer wall smooth; perianth lobes caducous; pedicel stout, obconical, c. $4 \mathrm{~mm}$ long, c. $2 \mathrm{~mm}$ diam, minute-appressed hairy.

Distribution - Endemic to Borneo, known only in Sarawak (Bau, Sri Aman and Tatau districts).

Habitat \& Ecology - Mixed dipterocarp forest on sandy clay soil at altitudes to $850 \mathrm{~m}$.

Vernacular names - Kayu buan, Tabar (both Iban), Medang lawang (Malay), Tiburus obau (Dayak).

Uses - Decoction of boiled root is used as tonic drink, for flatulence and for uterus contraction after delivery ( $S$ 68813).

Note - This species resembles $C$. sintoc in having a similar cupule that is deeply cup-shaped with an entire rim. However C. paiei can be differentiated from $C$. sintoc by its oblongovate leaves, $12-20$ by $3.5-7 \mathrm{~cm}$ (vs elliptic to ovate-elliptic, $(8-) 9-13(-20)$ by $3-5(-8) \mathrm{cm}$ ), lateral veins extending to the leaf tip (vs extending to $1 / 2-2 / 3$ the length of the leaf blade) and scalariform major intercostal veins (vs scalariform-reticulate).

\section{Cinnamomum pendulum Cammerl. - Map 5}

Cinnamomum pendulum Cammerl. (1925) 461; Kosterm. (1970b) 57. — Type: Labohm 2089 = bb 1099 (holo BO), Kalimantan, Kuala Kapuas, Sungai Ruhung.
Cinnamomum microcarpum Kosterm. (1970b) 54; J.A.R.Anderson (1980) 223; Beaman etal. (2001)399, syn. nov. - Type: Chew, Corner \& Stainton RSNB 8 (holo BO; iso K, L, SAN, SAR, SING), Sabah, Gunung Kinabalu.

Cinnamomum soepadmoi Kosterm. (1970b) 68, syn. nov. - Type: Kostermans 7389 (holo BO; iso L, PNH, SING), East Kalimantan, Balikpapan, Gunung Beratus.

Tree 10-26 m high, 14-45 cm diam. Bark smooth, greyish brown; inner bark reddish to pale brownish, strongly scented with cinnamon or nutmeg smell. Twigs slender, apically terete to slightly angular, c. 2-3 mm diam, glabrous; young twig apically appressed hairy. Terminal buds not perulate, conical, c. $2 \mathrm{~mm}$ long, glabrous or sparsely covered with minute appressed hairs. Leaves opposite or subopposite, triplinerved or trinerved, chartaceous to coriaceous, glabrous below; blade not bullate, without domatia, ovate, oblong-ovate, elliptic or lanceolate, $8-19$ by $(3-) 4-5(-5.5) \mathrm{cm}$, base cuneate, slightly attenuating, apex acute, tip often gnawed; midrib raised on both sides, slender, to $1 \mathrm{~mm}$ broad; lateral veins flat or raised above, raised below, slender, ending at the leaf tip; major intercostal veins indistinct, slender, scalariform, to 1-4 mm apart, less prominent than midrib; minor intercostal veins indistinct, reticulate; petiole slender, terete or flat above, glabrous, c. $0.8-1 \mathrm{~cm}$ long, c. 1-1.5 mm diam. Inflorescences axillary and/or subterminal, stout or slender, paniculatecymose, with first and second order branching, c. $8 \mathrm{~cm}$ long, minute-appressed hairy; rachis slender, to $1 \mathrm{~mm}$ broad. Flowers drying greyish, appressed hairy; pedicel 2-3 mm long, to $1 \mathrm{~mm}$ diam, slender; hypanthium c. $1 \mathrm{~mm}$ high; perianth lobes ovate, c. $2.5 \mathrm{~mm}$ long, appressed hairy; fertile stamen c. $2 \mathrm{~mm}$ long; anthers of the first and second whorl 4-locular, those of the third whorl 2- or 4-locular, filaments $2 / 3-3 / 4$ the length of the stamen; glands sessile, attached on each side at the base or lower half of filaments; staminodes c. $1 \mathrm{~mm}$ long, sagittate; ovary ellipsoid, c. $1 \mathrm{~mm}$ long, stigma peltate. Infructescences to $17 \mathrm{~cm}$ long, erect. Fruits oblong-ellipsoid, $1-1.5$ by $0.8 \mathrm{~cm}$, dark blue when fresh; cupule cup-shaped, shallow, 1-4 mm high, 4-7 mm diam, abruptly constricted to pedicel, rim entire, undulating, outer wall with faint longitudinal ridges, minutely hairy; perianth lobes caducous; pedicel c. $2 \mathrm{~mm}$ long, c. $1 \mathrm{~mm}$ broad, minutely hairy.

Distribution - Endemic to Borneo: Sarawak (Bintulu, Marudi, Miri, Lundu, Sri Aman and Tatau districts), Sabah (Ranau district), Brunei and Kalimantan (East, Central and West).

Habitat \& Ecology — In primary mixed dipterocarp and submontane forest on shallow sandy clay soil or sandstone-derived soils on ridges at 650-1100 m altitudes.

Vernacular names — Lawang, Medang tija (both Malay).

Note - Additional collections from Borneo have revealed more information on the vegetative variation within this species. Cinnamomum microcarpum, C. pendulum and C. soepadmoi share the same leaf characters in having glabrous blade, cuneate to slightly attenuating base, acute apex without acumen and lateral veins extending to the leaf tip. In addition to this, their fruit cupules are similar in that they are small, shallow, cup-shaped, abruptly constricted to the pedicel, with undulating rim and the cupule outer wall with faint longitudinal ridges. The foregoing characters also distinguish C. pendulum from other Bornean species.

\section{Cinnamomum percoriaceum Kosterm. - Map 5}

Cinnamomum percoriaceum Kosterm. (1970b) 58; J.A.R.Anderson (1980) 223. - Type: Illias S 26395 (holo SAR; iso BO, K, L, SAN, SING), Borneo, Sarawak, Lawas district.

Small tree to $6 \mathrm{~m}$ tall, to $7 \mathrm{~cm}$ diam. Twigs stout, angular, c. 3 $\mathrm{mm}$ diam, glabrous, drying blackish, discolorous to leaf blade. Terminal buds not perulate, conical, c. $2 \mathrm{~mm}$ long, densely 
covered with straight appressed hairs. Leaves opposite or subopposite, yellowish brown, trinerved, thickly coriaceous, glabrous below; blade not bullate, without domatia, elliptic to ovate, $7-12(-18)$ by $2.5-7(-9) \mathrm{cm}$, base cuneate, slightly attenuating to the pedicel, apex acute; midrib raised on both sides, c. $1 \mathrm{~mm}$ broad; lateral veins raised on both sides, extending to the base of acumen; major intercostal veins slender, raised, scalariform to subscalariform, 1-10 $\mathrm{mm}$ apart, less prominent than midrib; minor intercostal veins faint, reticulate; petiole stout to slender, flat above, glabrous, c. $1 \mathrm{~cm}$ long, c. 1-3 mm diam, blackish, drying discolorous to leaf blade. Inflorescences terminal, stout, paniculate-cymose with up to third order branching, 10-20 cm long; rachis $2-3 \mathrm{~mm}$ broad, sparsely appressed hairy. Flowers (at anthesis) appressed hairy; pedicels stout, c. $4 \mathrm{~mm}$ long; hypanthium c. $3 \mathrm{~mm}$ high; perianth lobes elliptic, c. $3 \mathrm{~mm}$ long, appressed hairy on both sides; fertile stamens $2-3 \mathrm{~mm}$ long, anthers ovoid; that of first and second whorl stamens 4-locular, that of third whorl 2-locular, filaments $1 / 2-2 / 3$ the length of the stamen; glands sessile on each side at the middle of filaments; staminodes c. $1.5 \mathrm{~mm}$ long, hastate; ovary globose, $2 \mathrm{~mm}$ diam, stigma trilobed. Fruits ellipsoid 5 by $3 \mathrm{~mm}$, cupule cup-shaped, $2 \mathrm{~mm}$ high, $3.5 \mathrm{~mm}$ diam, rim entire, not undulating, outer wall smooth; perianth lobes caducous; pedicel c. $2 \mathrm{~mm}$ long, c. $1 \mathrm{~mm}$ broad, glabrous.

Distribution - Endemic to Borneo, known only from Sarawak (Limbang and Sri Aman districts).

Habitat \& Ecology — In montane forest; altitudes to $2000 \mathrm{~m}$.

Note - Previously this species was only known from the type locality in Lawas district but here it is also found to occur in Limbang district (S 26395) and Sri Aman district (S 45066). Cinnamomum percoriaceum resembles $C$. sintoc but differs in the lateral veins that extend to the leaf tip (vs extend to $1 / 2-2 / 3$ the length of the leaf blade).

\section{Cinnamomum politum Miq. - Map 5}

Cinnamomum politum Miq. (1864) 265; Merr. (1921) 273; Cammerl. (1925) 493; Masam. (1942) 309; Kosterm. (1964) 340; (1970b) 59; Coode et al. (1996) 151. - Type: Korthals s.n. (lecto U, barcode U0002664, here designated; iso L, barcodes L0035920, L0035921, L0035922), Kalimantan, Mt Sakoembang.

Cinnamomum xylophyllum Kosterm. (1969) 467; (1970b) 59; J.A.R.Anderson (1980) 223. - Type: Kostermans 13067 (holo BO; iso BM, L, SING), Kalimantan, West Kutei, G. Palimasan, Belajan river, near Tabang.

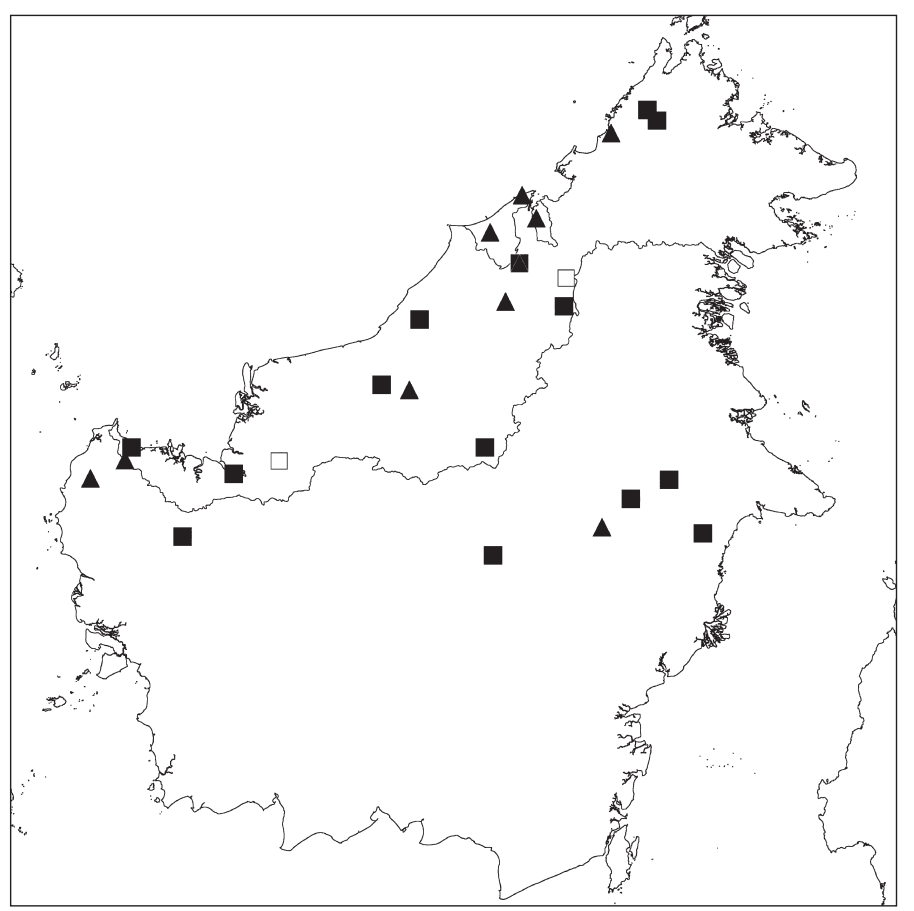

Tree to $30 \mathrm{~m}$, to $75 \mathrm{~cm}$ diam. Bark smooth or mottled, brownish or greyish; inner bark orange or reddish, fragrant with clove scent; sapwood yellowish or whitish. Twigs terete, 2-3 mm diam, glabrous, apically subangular, glabrous, dark brown. Terminal buds not perulate, conical, c. $4 \mathrm{~mm}$ long, glabrous. Leaves opposite or subopposite, drying yellowish brown, triplinerved or trinerved, thickly coriaceous, glabrous below; blade not bullate, without domatia, ovate, elliptic to lanceolate, $5-10(-12)$ by $2-5 \mathrm{~cm}$, base cuneate, slightly attenuating to the petiole, apex acuminate or acute with blunt tip, acumen to $1 \mathrm{~cm}$ long; midrib c. $1 \mathrm{~mm}$ broad, slender, raised above, and flat below; lateral veins raised above, flat below, extending to the base of acumen; major intercostal subscalariform, veins 1-2 $\mathrm{mm}$ apart, slender, obscure; minor intercostal veins obscure, reticulate; petiole $1(-1.5) \mathrm{cm}$ long, $1-1.5 \mathrm{~mm}$ diam, grooved above, glabrous. Inflorescences axillary or subterminal, paniculate-cymose with first and second order branching; to $10 \mathrm{~cm}$ long, rachis angular, c. $1 \mathrm{~mm}$ broad, sparsely minute-appressed hairy; bracts caducous. Flowers appressed hairy; pedicel to $4 \mathrm{~mm}$ long; hypanthium c. $1 \mathrm{~mm}$ high; perianth lobes elliptic, 2-3 mm long, appressed hairy; fertile stamens c. $2 \mathrm{~mm}$ long, anthers of first and second whorl stamens 4-locular, that of third whorl 2- or 4-locular, ovoid with truncate tip, filaments c. $2 / 3$ the length of the stamen; glands sessile and attached at middle of filament; staminodes c. $1 \mathrm{~mm}$ long, sagittate; ovary ellipsoid to globose, c. 1-2 mm long, stigma peltate. Fruits ellipsoid, c. 1 by $0.7 \mathrm{~cm}$; cupule cup-shaped, $6-7 \mathrm{~mm}$ high, c. $4 \mathrm{~mm}$ diam, glabrescent; perianth lobes persistent, triangular, c. 3 by $2 \mathrm{~mm}$, appressed hairy; pedicel stout, terete, c. $2 \mathrm{~mm}$ long, c. 1 $\mathrm{mm}$ diam.

Distribution - Endemic to Borneo: Sarawak (Bintulu, Lundu, Marudi and Miri districts), Sabah (Papar district), Brunei and East Kalimantan.

Habitat \& Ecology — In mixed dipterocarp forest on leached sandy soil, podsolised white sand or sandstone-derived soil, and also in kerangas and submontane forest at altitudes to $1000 \mathrm{~m}$.

Vernacular names - But (Penan), Medang keplah, Medang lawang (both Malay).

Uses - The wood is traded under the name medang. The bark is mixed in hot drink such as coffee and is believed to give strength and relieve muscle pain.
Map 5 Distribution of Cinnamomum pendulum Cammerl. (ש), C. percoriaceum Kosterm. ( $\square$ ) and C. politum Miq. ( $\mathbf{\Delta}$ ). 
Notes - 1. Kostermans initially described C. xylophyllum as a new species in 1969 but later reduced it to C. politum in 1970b. Cinnamomum xylophyllum only differs from $C$. politum by having 2-locular anthers at the third whorl of stamens (vs 4-locular) but vegetatively they are similar in having thickly coriaceous leaf and flat lateral veins at leaf undersurface. In comparison to the other Bornean species, C. politum is easily discriminated by its glabrous leaf blade, flat midrib and lateral veins on the leaf abaxial and persistent triangular perianth lobes on cupule.

2. The specimens from submontane forest up to $1470 \mathrm{~m}$ have smaller leaf size and shorter inflorescence length ( $S$ 47323, $S 47357$ and $S 60555)$ than the lowland specimens.

\section{Cinnamomum porrectum (Roxb.) Kosterm. - Map 6}

Cinnamomum porrectum (Roxb.) Kosterm. (1952) 27; (1970b) 60; Argent et al. (1997) 310; Beaman et al. (2001) 400. - Laurus porrectum Roxb. [(1814) 30] (1832) 308. - Camphora porrecta (Roxb.) Voigt (1845) 308. - Parthenoxylon porrectum (Roxb.) Blume (1851) 323. - Type: Roxburgh s.n. (holo P, barcode P00476750), Hortus Botanicus Calcuttensis, annotated on ex Herbario Musei Britannici 'Roxburgh, India', on a ticket with the annotation 'Laurus, Caya-ghadice'.

Laurus parthenoxylon Jack (1820) 28. - Camphora parthenoxylon (Jack) Nees (1831) 72. - Sassafras parthenoxylon (Jack) Nees (1836) 491, 657. - Cinnamomum parthenoxylon (Jack) Meisn. (1864) 26, 504; Masam. (1942) 308; F.G.Browne (1955) 215; Smythies (1965) 75; P.F.Burgess (1966) 332; J.A.R.Anderson (1980) 222. - Type: Jack s.n. (BR n.v.), Sumatra (fide Kostermans 1970b: 60).

Camphora inodora Blume ex Miq. (1958) 904. - Cinnamomum inodorum (Blume ex Miq.) Meisn. (1864) 26. - Type: Korthals s.n. (L), Borneo.

Cinnamomum penninervium Kosterm. (1969) 461, syn. nov. - Type: Anon. bb 5700 (holo BO; iso K, L), Indonesia, West Sumatra, Tapanuli, Kg. Pandumaan.

(for further synonyms and types see Kostermans 1970b; for further synonyms in East Asia see Li et al. (2008) under Cinnamomum parthenoxylon)

Tree to $50 \mathrm{~m}$ high, to $60 \mathrm{~cm}$ diam. Bark fissured, reddish or brownish; inner bark laminated, reddish brown, fragrant; sapwood yellowish white. Twigs terete, 2-5 $\mathrm{mm}$ diam, glabrous and striated, brownish. Terminal buds perulate, domed shaped, c. 5 by $4 \mathrm{~mm}$, with many tiered scales which after falling leaving a collar of scars in the twig, scales covered with straight appressed hairs. Leaves alternate, penninerved, chartaceous to subcoriaceous, hairy pocketed domatia present at proximal

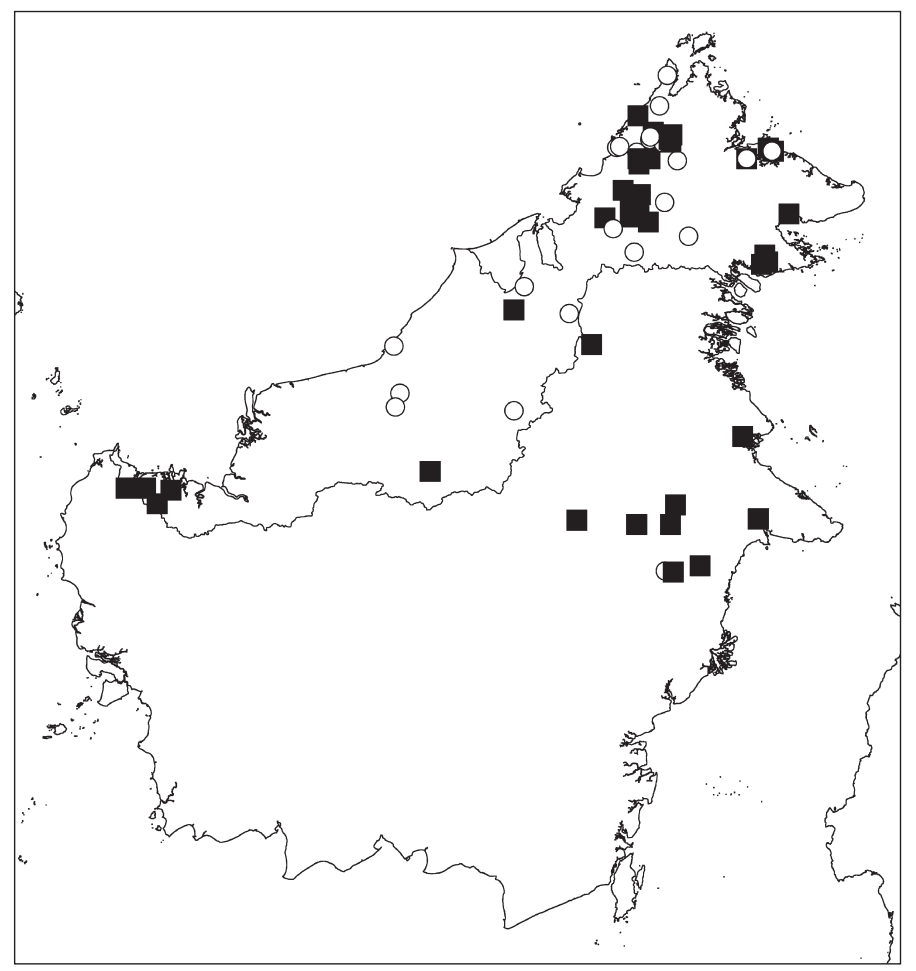

ends of lateral veins, glabrous below; blade elliptic, ovate or obovate, $4-17$ by $2-8 \mathrm{~cm}$, base cuneate, narrowly cuneate or rounded, apex acuminate, acumen to $2 \mathrm{~cm}$ long; midrib slender, to $1 \mathrm{~mm}$ broad, flat above, raised below; lateral veins slender, flat above and smoothly raised below, inarching and diminishing towards the leaf margin; intercostal veins reticulate; petiole $1-2.5 \mathrm{~cm}$ long, slender, grooved above. Inflorescences axillary, and/or subterminal, lax, slender, paniculate-cymose with first order of branching, (3-)4-7(-8) cm long, glabrous. Flowers glabrous, yellowish when fresh, appearing with the new flush, drying reddish; pedicel slender, 2-3 $\mathrm{mm}$ long; hypanthium campanulate, c. $1 \mathrm{~mm}$ high, conspicuous; perianth lobes elliptic, c. $1.5 \mathrm{~mm}$ long, glabrous outside, straight hairy on the inside; fertile stamens 1-1.5 mm long, anthers 4-locular, square, filaments c. 1/2 the length of the stamen; glands attached to short stalk at the base of filaments; staminodes sagittate, c. $1 \mathrm{~mm}$ long; ovary ellipsoid, c. 1.5-2 mm long, stigma subpeltate. Fruits globose, 5-6 mm diam; cupule funnel-shaped, c. $1 \mathrm{~mm}$ high, c. $0.5 \mathrm{~mm}$ diam, rim entire, glabrous; perianth lobes caducous; pedicel obconical, 9-10 mm long, 2-4 mm diam at distal part, tapering to $1 \mathrm{~mm}$ diam at base.

Distribution - Sarawak (Kuching and Lundu districts), Sabah (Keningau, Kota Belud, Lahad Datu, Pensiangan, Ranau, Sandakan, Tambunan, Tawau and Tenom districts) and East Kalimantan. This species is widespread and is also distributed in India, China, Indochina and Thailand, Sumatra, Java and Peninsular Malaysia.

Habitat \& Ecology - Lowland to montane forest at altitudes to $2000 \mathrm{~m}$, often found in secondary vegetation.

Vernacular names - Bunsud (Kadazan), Keplah wangi, Ludong, Medang, Medang keplah, Medang sasi, Medang wangi (all Malay).

Uses - The wood is used for general construction and furniture making. It is resistant to insect attack because of its pronounced and persistent smell. The bark is used in flavouring food, as tonic for menstruation and as scent for soap. The roots are used medicinally against fever, and applied after childbirth. (For more details see Burkill 1966).

Notes - 1. The oldest name for this species is Laurus porrecta Roxb. which is considered as validly published in Hortus
Map 6 Distribution of Cinnamomum porrectum (Roxb.) Kosterm. ( $\square$ ) and C. racemosum Kosterm. (O). 
Bengalensis (Roxburgh 1814) with reference to the work of Marsden (1811) under 'Cayoo-gaddess' (see Robinson 1912).

2. This is a very polymorphic species in leaf size, shape and texture. On the basis of leaf type two forms can be distinguished, the first with a small less pointed leaf apex and thinly coriaceous lamina, the second with a larger leaf size and a more pointed leaf apex and chartaceous lamina. These might represent varieties and deserve further study. Despite the variatibility, C. porrectum is readily distinguished by its perulate bud, penninerved leaf, domatia on lower leaf surface, slender inflorescences with up to first order branching that often come out together with newly flushed shoot, flowers with campanulate hypanthium and perianth lobes that are glabrous outside and hairy inside, and funnel-shaped cupules with globose fruit. This revision follows Kostermans (1970b) in recognising a broad species concept of C. porrectum (for further synonyms see Kostermans 1970b).

3. Cinnamomum penninervium has slightly thicker leaf texture but all other characters are conform with $C$. porrectum. One specimen from Sabah (SAN 89440) also has an unusually thick leaf.

\section{Cinnamomum racemosum Kosterm. - Map 6}

Cinnamomum racemosum Kosterm. (1969) 463; (1970b) 62; J.A.R.Anderson (1980) 223. - Type: Ashton S 18310 (holo BO; iso K, KEP, L, SAN, SAR, SING), Sarawak, Bintulu district, Ulu Sinrok, Semilajau Forest Reserve. Cinnamomum dictyoneuron Kosterm. (1969) 459; Beaman et al. (2001) 399. - Type: Endert 3687 (holo BO; iso L), Kalimantan, West Kutei, near Mt Kemul, river Telen.

Medium-sized tree to $12 \mathrm{~m}$ high, to $20 \mathrm{~cm}$ diam. Bark smooth, greyish white; inner bark reddish brown; sapwood yellowish. Twigs terete, 3-4 mm, apically angular, glabrous, yellowish brown, end of twig often with three leaves that are arranged closely in spiral. Terminal buds not perulate, conical, 3-4 mm long, densely covered with straight appressed hairs. Leaves subopposite or alternate, at twig-end leaves are arranged closely in spiral, trinerved, coriaceous, glabrous below; blade not bullate, without domatia, elliptic to ovate, $7-32$ by $3-13 \mathrm{~cm}$, base cuneate or rounded, distinctly and abruptly attenuating tapering toward petiole, apex acute with blunt tip and often gnawed, acumen often not distinct, if distinct up to $2 \mathrm{~cm}$ long; midrib $0.5-1 \mathrm{~mm}$ broad, distinctly raised on both sides; lateral veins raised on both sides, extending to the leaf tip or at the base of acumen; major intercostal veins $2-15 \mathrm{~mm}$ apart, smoothly raised and faint, scalariform; minor intercostal veins obscure, reticulate; petiole (0.8-)1-2(-2.5) cm long, 1-2(-3) mm diam, glabrous, subterete, shallowly grooved above or sometimes flat above. Inflorescences axillary and/or terminal, 1.5-13(-17.5) $\mathrm{cm}$ long, first to second order branching, racemiform, glabrous. Flowers glabrous outside; pedicel 3-6 mm long; hypanthium c. $1 \mathrm{~mm}$ high; perianth lobes elliptic, 2-2.5 mm long, appressed hairy inside, glabrous outside; fertile stamens 1.5-2 mm long, anthers 4-locular, ovoid with truncate apex, filaments c. $2 / 3$ the length of the stamen, appressed hairy; glands on a short stalk attached at the base of third whorl filaments; staminodes sagittate, 1-1.5 mm long, with laterally bulging and thick glands; ovary subglobose, 1-1.5 mm long, stigma peltate. Fruits ellipsoid or obovoid, $0.9-1.1$ by $0.7-0.8 \mathrm{~mm}$, glabrous; cupule cup-shaped, thick, 6-7 mm high, c. $4 \mathrm{~mm}$ diam, glabrous; perianth lobes partially persistent with upper half of perianth lobes abscised, c. 2 by $1 \mathrm{~mm}$, apex truncate, glabrous; pedicel 2-5 mm long, 1.5-2 $\mathrm{mm}$ diam.

Distribution - Endemic to Borneo: Sarawak (Bintulu and Miri districts), Sabah (Kinabatangan, Kota Belud, Kota Kinabalu, Kota Marudu, Penampang, Pensiangan, Ranau, Sandakan, Tenom and Tuaran districts) and East Kalimantan.
Habitat \& Ecology - In various types of forest at altitudes to $1500 \mathrm{~m}$.

Vernacular names - Baulong (Kenyah), Buhau baya(Penan), Kayu manis, Kebu-kebu, Lawang, Medang teja, Medang tiga, Medang tiga urat (all Malay), Sakang seribu (Iban).

Uses - In Sabah and Sarawak, the local people consume a root decoction of $C$. racemosum to repel evil spirit ( $S$ 60606). The fumes from bark, wood and leaves are used as fumigant.

Notes - 1. After having examined the types and new material identified as C. dictyoneuron (e.g., Jusimin 514, Jamili Nais SNP 3057, SAN 26737, FRI 36251, SAN 48142, SAN 73517, SAN 76182, SAN 94393, SAN 122026 and SAN 127717) and C. racemosum (e.g., S 3711, S 3810, S A 3861, FMS 10182, FMS 48956 and SAN 120498), I am of the opinion that they are conspecific because they show a similar type of inflorescence (racemiform), fruit cupule (perianth lobes partially persistent) and leaf arrangement at twig-end (spirally arranged). The length of petiole and inflorescence, and shape of fruit are morphologically variable within this species. However, the foregoing characters of inflorescence, fruit cupule and leaf arrangement are useful to distinguish $C$. racemosum from the other Bornean species.

2. Some specimens collected from Sabah have smaller leaf size, $8-12$ by $3-4 \mathrm{~cm}$ (Jusimin 389 , Pereira JTP 508, SAN 26737, SAN 76227 and SAN 86071). However, other characters are conform to $C$. racemosum.

\section{Cinnamomum rhynchophyllum Miq. - Map 7}

Cinnamomum rhynchophyllum Miq. (1858) 895; Cammerl. (1925) 481; Masam. (1942) 308; Kosterm. (1970b) 62. - Type: Teijsmann H.B. 1031 (holo $\mathrm{U}$; iso BO), Sumatra, Loeboe Along.

Cinnamomum lampongum Miq. (1860) 142, 358. - Cinnamomum rhynchophyllum var. lampongum (Miq.) Ridl. (1924) 93. - Type: Teijsmann H.B. 4550 (holo BO; iso U n.v.), Sumatra, Lampong, Mt Batin.

Small tree to $10 \mathrm{~m}$ tall, to $15 \mathrm{~cm}$ diam. Bark smooth or lenticellate, greyish brown; inner bark light brown to reddish, fragrant; sapwood yellowish or whitish. Twigs terete, 2-3 mm diam, apically angular, appressed hairy or glabrous, brown to light brown. Terminal buds not perulate, conical, c. $4 \mathrm{~mm}$ long, densely covered with straight appressed hairs. Leaves opposite or subopposite, trinerved, thinly coriaceous, sparsely straight appressed hairy below; blade not bullate, without domatia, elliptic or oblong, $13.5-20$ by $3.5-6.5(-8) \mathrm{cm}$, base narrowly cuneate, shortly attenuate, apex caudate, abruptly constricted, forming a slender and appendage-like acumen, 0.5-1.5(-2.5) $\mathrm{cm}$ long; midrib c. $1 \mathrm{~mm}$ broad, distinctly raised on both sides, distinctly angular below; lateral veins distinctly raised on both sides, extending to the base of acumen; major intercostal veins scalariform to subscalariform, 1-2(-3) mm apart, less prominent than midrib; minor intercostal veins indistinct, reticulate; petiole 1-2 cm long, 1-2 mm diam, appressed hairy, flattish or inconspicuously grooved above. Inflorescences axillary and/or subterminal, paniculate-cymose with second or third order branching, appressed hairy, 14-20 cm long. Flowers hairy, pedicel $3-5 \mathrm{~mm}$ long ; hypanthium c. $1 \mathrm{~mm}$ high; perianth lobes elliptic, broadly elliptic or ovate, c. $2 \mathrm{~mm}$ long, appressed hairy on both sides; fertile stamens $1.5-2 \mathrm{~mm}$ long, anthers 2-locular, ovoid with truncate or obtuse tip, filaments c. 3/4 the length of the stamen, appressed hairy; glands shortly stalked and attached at the middle of filaments; staminodes c. $1 \mathrm{~mm}$ long, hastate; ovary subglobose, c. $1 \mathrm{~mm}$ across, stigma peltate. Fruits ellipsoid, c. 1 by $0.8 \mathrm{~cm}$; cupule shallow, c. $1 \mathrm{~mm}$ high, c. $3 \mathrm{~mm}$ diam; perianth lobes persistent, elliptic, c. 3 by $2 \mathrm{~mm}$; pedicel c. $3 \mathrm{~mm}$ long.

Distribution - Sarawak (Kuching, Lundu and Marudi district), Sabah (Lahad Datu and Tawau districts), and West, Central and 
East Kalimantan. This species is also distributed in Sumatra and Peninsular Malaysia.

Habitat \& Ecology — In mixed dipterocarp forest at altitudes to $600 \mathrm{~m}$.

Vernacular names - Berawit (Kelabit), But (Penan), Medang kepla, Medang tija (both Malay).

Uses - The bark is used as a spice and a decoction of the leaves is used to treat stomach ache and food poisoning.

Notes -1 . This species is widely distributed in the Western Malesian region. Kostermans (1970b) stated that C. rhynchophyllum is absent in Peninsular Malaysia. However, recent studies (Kochummen 1989 and this study) show that C. rhynchophyllum is widely distributed in Peninsular Malaysia (e.g., FMS 34235, FMS 35167, FRI 19831, FRI 28886, KEP 105186, KEP 110414 and Ogata 10443).

2. This species resembles $C$. cuspidatum in having caudate leaf apex and 2-locular anthers, but can be differentiated by its hairy leaf (vs glabrous), shallow and indistinct cupule (vs distinct and funnel-shaped), midrib angular below (vs smoothly raised) and inflorescence 14-20 cm long (vs 4-7 cm long) with second or third order branching (vs first order).

\section{Cinnamomum sintoc Blume - Map 7}

Cinnamomum sintoc Blume (1826) 571; Merr. (1921) 273; Cammerl. (1925) 455; Masam. (1942) 309; P.F.Burgess (1966) 332; Kosterm. (1970b) 64; Argent et al. (1997) 310. - Type: Blume s.n. (holo L, sheet no. 905229197; iso BO, sheet no. BO1267347), Java.

Laurus callophyllum Reinw. ex Nees \& T.Nees (1823) 63, nom. nud. — Cinnamomum calophyllum Reinw. ex Nees (1836) 40. - Type: Reinwardt s.n. (L n.v.) (fide Kostermans 1970b: 64).

Laurus pseudocassia Reinw. ex Blume (1823) 67, nom. nud. - Representative specimen: Reinwardt s.n. (L, barcode L0035825), Asia.

Cinnamomum camphoratum Blume (1826) 571. - Type: Blume 870 (holo L, barcode L0035971), Mt Seribu.

Cinnamomum pseudosintok Miq. (1858) 902. - Type: Junghuhn s.n. (lecto $\mathrm{L}$, barcode L0035975, here designated; iso L, barcode L0035976, K), Java, Preanger.

Cinnamomum laxiflorum Meisn. (1864) 21. - Type: de Vriese s.n. (lecto L, barcode L0035970, here designated; iso K), Java.

Cinnamomum cinereum Gamble (1910) 220; (1912) 84; Ridl. (1924) 96. - Type: Wray 2629 (lecto K, designated by Kosterm. (1970b: 64); iso BM, E, SING), Peninsular Malaysia, Perak, Waterfall Hill. — Syntype: King 8515 (BO, K), Peninsular Malaysia, Perak, Taiping.

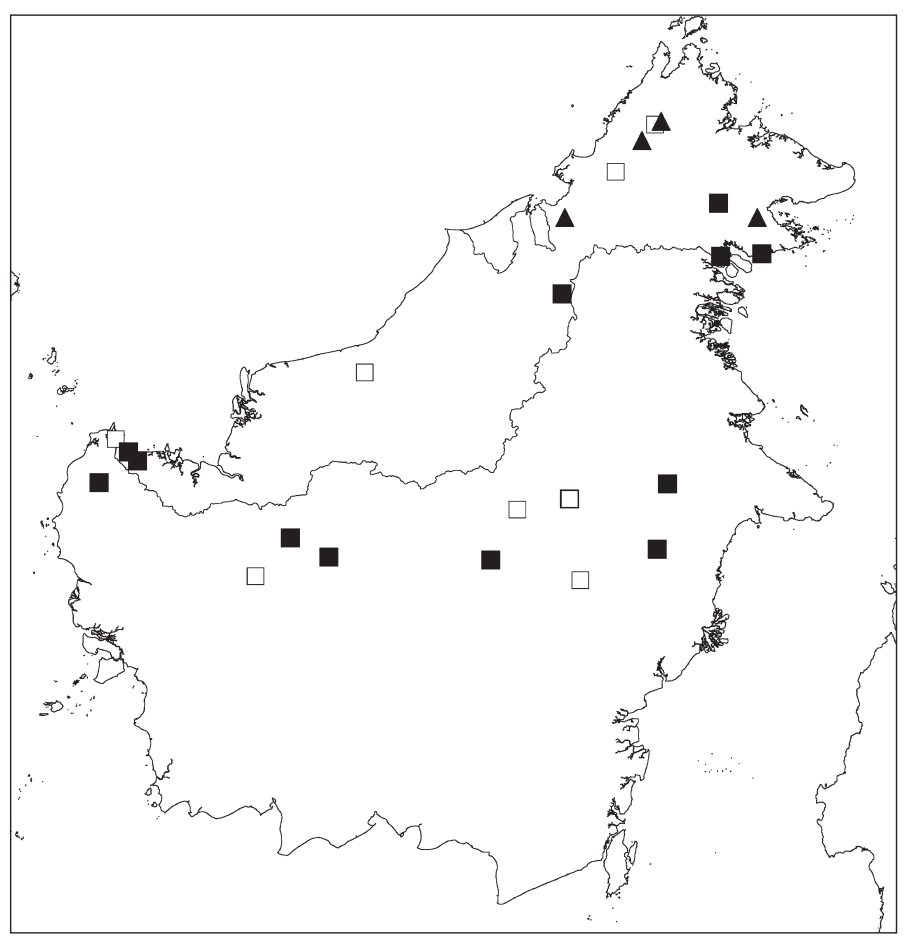

Cinnamomum coriaceum Cammerl. (1925) 475. - Type: Endert 149 E ip 841 (holo BO, sheet no. BO1267345; iso BO, sheet no. BO1267346, L, sheet no. 925206251), Sumatra, Banjuasin and Kubu area. - Syntypes: bb 2567 (BO), Sumatra, Aceh, Langsa; bb 2769 (BO), Sumatra, Bengkulu, Mt Aning; Grashoff 564 (BO), Sumatra, hulu Komering.

Tree to $27 \mathrm{~m}$ tall, to $30 \mathrm{~cm}$ diam. Bark smooth, light brown; inner bark reddish brown, strongly smelling of nutmeg. Twigs stout, terete, $1.5-2.5 \mathrm{~mm}$ diam, glabrous, drying blackish. Terminal buds not perulate, conical, c. $2 \mathrm{~mm}$ long, glabrous. Leaves opposite or subopposite, drying brownish, triplinerved, thickly coriaceous, glabrous below; blade not bullate, without domatia, elliptic to ovate-elliptic, (8-)9-13(-20) by $3-5(-8) \mathrm{cm}$, base cuneate, apex acute; midrib raised on both surfaces, to $1 \mathrm{~mm}$ broad; lateral veins raised on both surfaces, extending to $1 / 2-2 / 3$ the length of leaf blade; major intercostal veins subscalariform-reticulate, faint, 3-5 mm apart, less prominent than midrib; minor intercostal veins faint, reticulate; petiole slender, drying blackish, discolorous to blade, 1-1.5 cm long, 1-1.5 mm diam, channelled above. Inflorescences axillary and/ or subterminal, stout, paniculate-cymose with first to second order branching, 5-8 cm long; rachis c. $1 \mathrm{~mm}$ broad, hairy. Flower densely hairy; pedicel c. $2 \mathrm{~mm}$ long; hypanthium c. 1.5 $\mathrm{mm}$ high, distinct; perianth lobes elliptic, c. $2 \mathrm{~mm}$ long, hairy on both sides; fertile stamens c. $2 \mathrm{~mm}$ long, anthers 4-locular, ovoid with truncate tip, filaments c. $2 / 3$ the length of the stamen; glands sessile on each side at the middle or lower half of filaments; staminodes c. $1 \mathrm{~mm}$ long, sagittate; ovary ellipsoid, c. $1 \mathrm{~mm}$ long, stigma peltate. Infructescence $10-20 \mathrm{~cm}$ long; rachis 1-1.5 mm broad, sparsely hairy. Fruits ellipsoid or obovoid, c. 10 by $8 \mathrm{~mm}$; cupule cup-shaped, deep, c. $6 \mathrm{~mm}$ high, c. $8 \mathrm{~mm}$ diam, rim entire, not undulating, glabrous; perianth lobes caducous; pedicel terete, c. $2 \mathrm{~mm}$ long, c. $1.5 \mathrm{~mm}$ diam, ridged horizontally.

Distribution - Sarawak (Lundu district), and West and East Kalimantan. This species is also distributed in Sumatra, Peninsular Malaysia and Java.

Habitat \& Ecology - In mixed dipterocarp forest on sandy soil, at altitudes to $60 \mathrm{~m}$.

Uses - The bark is sold commercially in the local market and used as medicine to treat diarrhoea and intestinal complaints. The powdered bark is used to treat wounds. 
Note - This species is distinguished from the other Cinnamomum species of Borneo by its glabrous leaf blade, lateral veins extending to $1 / 2-2 / 3$ the length of the blade and cupshaped fruit cupule with entire rim. Specimen $b b 28118$ and bb 29036 cited as C. pendulum and C. lawang in Kostermans (1970b) belong to C. sintoc.

\section{Cinnamomum soegengii Kosterm. - Map 7}

Cinnamomum soegengii Kosterm. (1970b) 67; Beaman et al. (2001) 400. - Type: Chew \& Corner RSNB 4750 (holo SAR, not found; iso K, SAN, SING), Sabah, Ranau district, Gunung Kinabalu, Mesilau.

Cinnamomum grandis Kosterm. (1988) 443; Beaman et al. (2001) 399, syn. nov. - Type: Wood SAN 16706 (holo L; iso BO, KEP, SAN, SING), Sabah, Sipitang district, Gunung Lumaku.

Tree to $40 \mathrm{~m}$ tall, $10-70 \mathrm{~cm}$ diam. Bark smooth, brownish; inner bark pink-reddish or orange-brownish. Sapwood yellowish whitish. Twigs stout, terete, apically subangular, $2-3 \mathrm{~mm}$ diam, glabrous, yellowish brown. Terminal buds not perulate, conical, 2-3 mm long, densely covered with straight appressed hairs. Leaves opposite or subopposite, yellowish brown, trinerved, coriaceous, glabrous below, occasionally remnant of straight appressed hairs from young leaves present on midrib of mature leaves; blade not bullate, without domatia, ovate to oblong-elliptic, $10-15(-20)$ by $3-6.5 \mathrm{~cm}$, base cuneate, apex acute; midrib raised on both sides, c. $1 \mathrm{~mm}$ broad; lateral veins raised on both sides, extending to the leaf tip; major intercostal veins slender, subscalariform, $2-3 \mathrm{~mm}$ apart, less prominent than midrib; minor intercostal veins indistinct, reticulate; petiole stout, subterete, glabrous, $1-1.5 \mathrm{~cm}$ long, c. $2 \mathrm{~mm}$ diam. Inflorescences axillary and/or subterminal, stout, paniculatecymose with second order branching, many-flowered, appressed hairy, to $9 \mathrm{~cm}$ long; rachis c. $1 \mathrm{~mm}$ broad. Flowers with appressed hairs; pedicels c. $3 \mathrm{~mm}$ long; hypanthium c. $1 \mathrm{~mm}$ high; perianth lobes elliptic, c. $2 \mathrm{~mm}$ long; fertile stamens c. 1.5 $\mathrm{mm}$ long, anthers 4-locular, ovoid with obtuse tip, filaments $\mathrm{c}$. $3 / 4$ the length of the stamen; glands sessile, attached at the middle of filaments; staminodes c. $1 \mathrm{~mm}$ long, sagittate; ovary subglobose, c. $1.5 \mathrm{~mm}$ across; stigma trilobed. Infructescences stout, $5-20 \mathrm{~cm}$ long; rachis $1-1.5 \mathrm{~mm}$ broad, appressed hairy. Fruits oblong-ellipsoid, $1.5-2$ by $1 \mathrm{~cm}$, bluish green when fresh; cupule cup-shaped, deep, 0.7-1 cm high, c. $1 \mathrm{~cm}$ diam, rim entire, not undulating, appressed hairy, wall smooth; perianth lobes caducous; pedicel stout, obconical, c. $5 \mathrm{~mm}$ long, c. $3 \mathrm{~mm}$ diam at apex tapering to $1 \mathrm{~mm}$ at base.

Distribution - Endemic to Borneo, known only in Sabah (Lahad Datu, Ranau, Sipitang and Tambunan districts).

Habitat \& Ecology - In mixed dipterocarp and lower montane forest at $700-1800 \mathrm{~m}$ altitudes.

Vernacular name - Medang teja (Malay).

Uses - The wood is used as timber.

Notes -1 . The only difference between the type of $C$. soegengii and C. grandis is that the leaf shape is ovate-elliptic or oblong, respectively. SAN 29076 and SAN 41798 show intermediate leaf shapes ranging from ovate, elliptic to oblong.

2. This species resemble $C$. sintoc but differs in its lateral veins extending to the leaf tip (vs lateral veins $1 / 2-2 / 3$ the length of leaf blade). The specimen Clemens 31108 annotated as C. sintoc in Kostermans (1970b) belongs to C. soegengii.

\section{Cinnamomum subavenium Miq. - Map 8}

Cinnamomum subavenium Miq. (1858) 902; Merr. (1921) 272; Cammerl. (1925) 452; Masam. (1942) 308; Kosterm. (1970b) 68; Argent et al. (1997) 310; Beaman et al. (2001) 400. - Type: Teijsmann H.B. 1032 and 1037 (holo U, in 2 sheets, barcodes U0002678, U0002677; iso BO), Sumatra, Solok.
Cinnamomum cyrtopodum Miq. (1858) 897. - Type: Teijsmann H.B. 1053 (holo BO; iso U, barcode U0002653), Solok, Sumatra.

Cinnamomum borneense Meisn. (May 1864) 19. - Type: Motley 796 (lecto $\mathrm{K}$, here designated; iso L), Kalimantan, Banjarmasin. - Syntype: Motley 853 (K n.v., L n.v.) Kalimantan, Banjarmasin.

Cinnamomum borneense Miq. (Oct. 1864) 260, nom. illeg., non Meisn. - Cinnamomum floribundum Miq. (Dec. 1864), nom. nov. - Type: Korthals s.n. (holo U, barcode U0002676; iso L, barcodes L0035989, L0035991, L0119675), South Kalimantan, Gunung Pamaton.

Cinnamomum glabrescens Miq. (1864) 264. - Type: Korthals s.n. (holo L, sheet no. 905220161), South Kalimantan, Gunung Pamaton.

Cinnamomum culitlawan Blume var. celebricum Teijsm. \& Binn. (1866) 92, nom. nud. - Representative specimen: Hort. Bogor sub V D 35 (BO n.v., L n.v.), cultivated in Hortus Bogoriense (fide Kostermans 1970b: 68).

Cinnamomum ridleyi Gamble (1910) 218. - Type: Ridley 4823 (holo K; iso L, barcode 0035987, SING), Singapore, Changi Road.

Cinnamomum nooteboomii Kosterm. (1988) 446, syn. nov. - Type: Nooteboom \& Chai 2102 (holo L; iso K, KEP, SAR), Sarawak, Marudi district, Kelabit Highlands.

(for further synonyms in East Asia see Li et al. 2008)

Tree 18-27 m tall, 13-50 cm diam. Bark smooth, greyish; inner bark finely fibrous, pinkish brown, fragrant; sapwood whitish or cream. Twigs slender, 2-3 mm diam, apically subangular, minute-appressed hairy, dark brown. Terminal buds not perulate, conical, c. $2 \mathrm{~mm}$ long, densely covered with straight appressed hairs. Leaves opposite, subopposite or rarely alternate, trinerved or triplinerved, subcoriaceous, appressed hairy below, hairs straight to curly, sometimes leaves silky below (e.g., SAN 138868); blade not bullate, without domatia, elliptic to narrowly elliptic, $(3.5-) 6-11(-14)$ by $(1.5-) 3-4 \mathrm{~cm}$, base narrowly cuneate and slightly attenuate, apex acuminate, acumen $0.5-1(-2) \mathrm{cm}$ long; midrib faint and flat above, prominent and smoothly raised below; lateral veins faint and flat above, prominent and raised below, ending at the base of acumen; major intercostal veins faint on both sides, slender, subscalariform, less prominent than midrib, 1-2(-3) $\mathrm{mm}$ apart; minor intercostal veins reticulate, obscure; petiole slender, $0.5-1.5 \mathrm{~cm}$ long, c. $1 \mathrm{~mm}$ diam, flat to shallowly grooved above, dark brown, appressed hairy. Inflorescences axillary and/or subterminal, paniculate-cymose with two to third order branching, densely appressed hairy, (4.5-)6-8(-10) cm long; rachis to c. $1 \mathrm{~mm}$ broad. Flowers yellowish red when fresh (SAN 61755), drying greyish, densely appressed hairy; hypanthium c. $1.5 \mathrm{~mm}$ high; perianth lobes elliptic, c. 2-3 $\mathrm{mm}$ long, appressed hairy on both sides; pedicel 2-3 mm long; fertile stamens c. $2 \mathrm{~mm}$ long, anthers 4-locular, ovoid obtuse to oblong truncate, filaments c. 1/2 the length of the stamen, hairy; glands adnate at the middle of filaments; staminodes 1.5-2 mm long, appressed hairy, sagittate; ovary oblong, c. $1 \mathrm{~mm}$ long, stigma trilobed. Fruits ellipsoid, c. 10 by $7 \mathrm{~mm}$, drying dark brown; cupule funnelshaped, flattish, c. $1 \mathrm{~mm}$ high, c. $2 \mathrm{~mm}$ diam, rim entire, slightly undulating; perianth lobes caducous, sparsely hairy; pedicel obconical, c. $3 \mathrm{~mm}$ long, hairy.

Distribution - Sarawak (Marudi and SriAman districts), Sabah (Ranau, Tambunan and Sipitang districts) and West Kalimantan. This species is also distributed in Sumatra and Peninsular Malaysia.

Habitat \& Ecology — In mixed dipterocarp to submontane forest at altitudes to $1500 \mathrm{~m}$.

Vernacular names - Berawith dari, Lekuah (both Kelabit), Kayu manis, Medang tiga urat (both Malay).

Uses - The wood is used as timber.

Note - Cinnamomum nooteboomii only differs from C. subavenium by its curly minute hairs on leaf undersurface (vs straight minute hairs). Both of these species share the same vegetative and reproductive structure by having elliptic to narrowly elliptic leaves, faint major intercostal veins, leaf apex with acumen measuring $0.5-1(-2) \mathrm{cm}$ long, and a cupule that is funnel-shaped, flattish and without persistent perianth lobes. 


\section{Cinnamomum subcuneatum Miq. - Map 8}

Cinnamomum subcuneatum Miq. (1858) 895; Meisn. (1864) 11; Cammerl. (1925) 471; Argent et al. (1997) 310. - Type: Teijsmann H.B. 1016 (holo $\mathrm{U}$, barcode U0002679; iso BO), West Sumatra, Kotanopan.

Cinnamomum subcuneatum Miq. var. $\beta$ Miq. (1858) 896. - Type: Teijsmann H.B. 1023 (holo U, barcode U0002680), Sumatra, Danau Maniendjo.

Cinnamomum griffithii Meisn. (May 1864) 19; Cammerl. (1925) 471; Kosterm. (1986) 53; Beaman et al. (2001) 398, syn nov. - Cinnamomum gracile Miq. (Dec. \& Oct. 1864) 259, 317, nom. superfl. - Type: Griffith 4240 (holo K; iso L, NY - fragment), Peninsular Malaysia, Malacca? (see note 4).

Tree or small tree 4-8(-12) $\mathrm{m}$ tall, $8-14 \mathrm{~cm}$ diam. Bark smooth, greyish brown or whitish; inner bark yellowish, orange, reddish or brownish in colour, scented; sapwood yellowish to whitish. Twigs stout or slender, terete, 2-3 mm diam, apically subangular, glabrous, drying dark brown to black. Terminal buds not perulate, conical, $2-3 \mathrm{~mm}$ long, densely covered with straight or curly hairs. Leaves opposite to subopposite, drying dark green, triplinerved or trinerved, thinly coriaceous, below sparsely or densely covered with wavy to curly hairs (c. $0.2-1$ $\mathrm{mm}$ ); blade not bullate, without domatia, lanceolate to oblongelliptic, $9-22$ by $3.5-9 \mathrm{~cm}$, base cuneate, apex acute, tip often gnawed; midrib prominent and smoothly raised on both sides, c. $0.5 \mathrm{~mm}$ broad; lateral veins raised on both sides, extending to leaf tip; major intercostal veins slender, subscalariform, 2-7 $\mathrm{mm}$ apart, less prominent than midrib; minor intercostal veins faint, reticulate; petiole stout or slender, subterete, shallowly grooved above, glabrescent, 1-1.5 cm long, 1-2 mm diam. Inflorescences axillary or subterminal, slender, drying blackish, paniculate-cymose with up to third order branching, 8-18 cm long; rachis angular, $1 \mathrm{~mm}$ broad sparsely to densely hairy, hairs straight to curly; bracts caducous. Flowers densely hairy, drying silky and greyish, yellowish when fresh; pedicels slender, 2-5 mm long; hypanthium 2-3 mm high; perianth elliptic, $1.5-2.5 \mathrm{~mm}$ long, appressed pilose on both sides; fertile stamen $1.5-2.5 \mathrm{~mm}$ long, anthers oblong ovate with truncate or obtuse tip; that of first and second whorl 4-locular, of the third whorl 2-locular, rarely 4-locular, filament $2 / 3-3 / 4$ of stamen length; glands shortly stalked or sessile on each side at the middle or lower half of the third whorl filaments, reniform; staminodes $1-1.5 \mathrm{~mm}$ long, apex sagittate; ovary ellipsoid, 1-1.5 mm long, stigma trilobed. Fruits ellipsoid or obovoid with pointed tip, c. 10 by $8 \mathrm{~mm}$; cupule cup-shaped, thick, distinct, c. $4 \mathrm{~mm}$

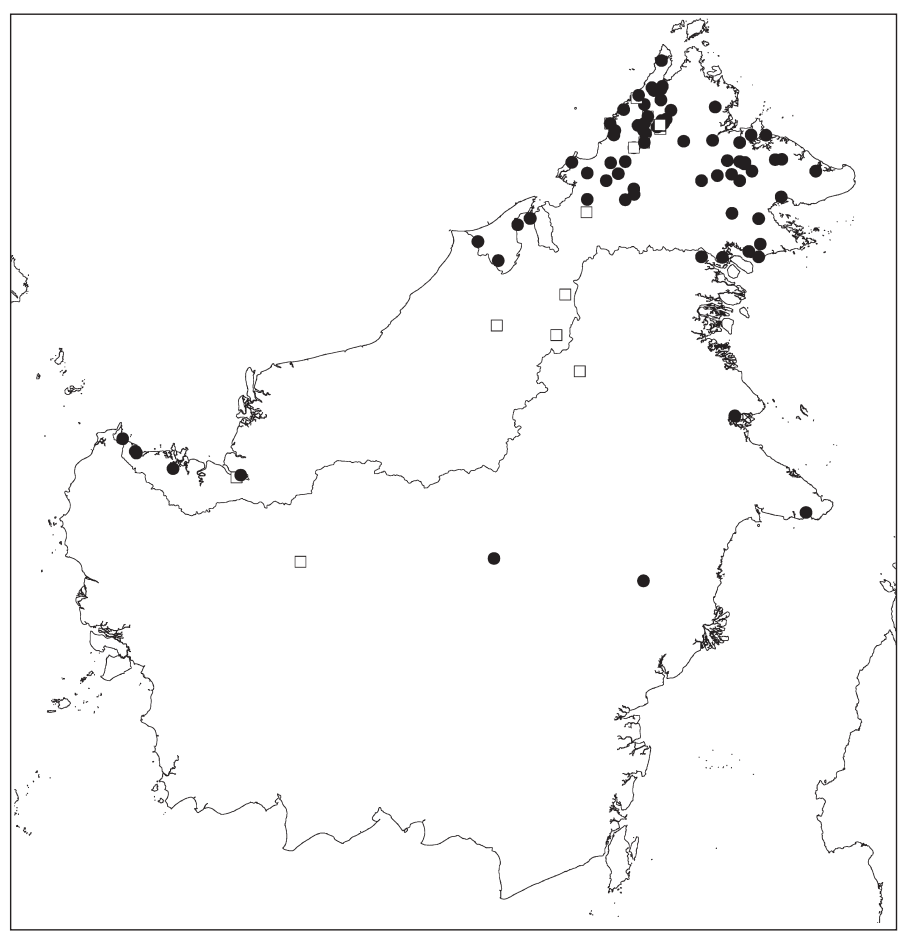

high, 4-6 mm diam, sparsely appressed hairy; perianth lobes persistent, drying not hardened, becoming thin, elliptic or ovate, c. 2 by $1-2 \mathrm{~mm}$; pedicel stout, $3-4 \mathrm{~mm}$ long, c. $1 \mathrm{~mm}$ diam, minute-appressed hairy.

Distribution - Sarawak (Kuching, Limbang, Lubok Antu and Lundu districts), Sabah (Beaufort, Keningau, Kinabatangan, Kota Belud, Kota Marudu, Kudat, Labuk Sagut, Lahad Datu, Penampang, Ranau, Sandakan, Tambunan, Tawau, Tenom and Tuaran districts), Brunei and Central and East Kalimantan. This is a widespread species distributed also in Peninsular Thailand, Sumatra, Peninsular Malaysia and the Philippines.

Habitat \& Ecology — In mixed dipterocarp, freshwater swamp, riparian, and lower montane forest at altitudes to $1500 \mathrm{~m}$.

Vernacular names - Babau, Daluh, Lamou-lamou, Rundaing, Salimuat, Tawar (all Dusun), Kayu manis, Keningau (both Malay), Lawang (Iban), Maliwat (Suluk), Mengarabau (Kadazan).

Uses - A decoction of the roots is given to women after childbirth and also to treat fever. The local people in Sarawak believe that the twigs of $C$. subcuneatum when placed at the edge of a paddy field will protect their crop from pests. In Sabah, the Orang Sungei tribe rubbed the pounded root on rheumatic joint to relieve pain.

Notes - 1. On the herbarium sheets, there have been many misidentifications involving $C$. griffithii, $C$. iners and $C$. subcuneatum. After having examined the herbarium specimens from Malesia, I recognise two distinct taxa, viz. C. iners and C. subcuneatum, including $C$. griffithii. Both of these species can be satisfactory differentiated by the leaf indumentum and the fruit cupule. Cinnamomum iners differs from $C$. subcuneatum in its leaf indumentum which is sparse, straight, short and to $0.2 \mathrm{~mm}$ long (vs denser, wavy to curly hairs, long, $0.2-1 \mathrm{~mm}$ ), and fruit cupule which is inconspicuous and shallow, c. $1 \mathrm{~mm}$ high, c. 2 $\mathrm{mm}$ diam. (vs conspicuous and thick, c. $4 \mathrm{~mm}$ high, c. 4-6 $\mathrm{mm}$ diam). The first and second whorl stamens of $C$. iners are always 4-locular. Some variation is observed in the third whorl anther locule of $C$. subcuneatum. The Bornean $C$. subcuneatum have 2-locular anthers in the third whorl (with exception of SAN 31460 and SAN 80764 which have 4-locular anthers). The Sumatran and Peninsular Malaysian specimens have 2- or 4-locular anthers in the third whorl stamens. 
2. In Peninsular Malaysia and Borneo, C. iners is frequently found at low altitude in open areas, secondary forest and by roadsides. It is widely planted as shade tree in urban landscapes. Cinnamomum subcuneatum is commonly found in secondary forest and primary forest ranging from lowland to montane forest. In Sumatra, the two species are observed in primary and secondary forest. In Java, $C$. iners is found only in primary forest.

3. Two specimens from Sabah (RSNB 2687 and SAN 18804) that were identified by Kostermans (1970a) as C. tahijanum belong to $C$. subcuneatum. Cinnamomum subcuneatum differs from C. tahijanum by its acute leaf apex (vs acuminate, with distinct acumen) and slender midrib and lateral veins, $0.5 \mathrm{~mm}$ broad (vs broad midrib, c. $1 \mathrm{~mm}$ broad).

4. Meissner (1864) cited, as the type of $C$. griffithii, an unnumbered Griffith specimen from Malacca in the Hooker herbarium. He further commented that this species resembles $C$. iners. Kostermans (1986) indicated the specimen Griffith 4240 as the type of $C$. griffithii. After having examined the collections in $\mathrm{K}$, I did not find any unnumbered Griffith's collection from Malacca. The specimen Griffith 4240 is the only collection from Peninsular Malaysia that resembles $C$. iners. I therefore concur with Kostermans (1986) that Griffith 4240 is the type of C. griffithii.

\section{Cinnamomum sublanuginosum Kosterm. - Map 9}

Cinnamomum sublanuginosum Kosterm. (1970b) 73; Beaman et al. (2001) 400. - Type: Chew \& Corner RSNB 7036 (holo SING; iso K, L, SAN, SAR), Sabah, Ranau district, Mesilau.

Cinnamomum woodii Kosterm. (1988) 454; Beaman et al. (2001) 401, syn. nov. - Type: Wood SAN 16377 (holo L; iso BO, KEP, SAN, SING), Sabah, Ranau district, Bundu Tuhan.

Tree 20-35 m tall, 30-50 cm diam. Bark brownish; inner bark reddish brown to yellowish; sapwood whitish. Twigs stout, terete, 3-4 mm diam, distinctly quadrangular apically. Terminal buds not perulate, conical to ellipsoid, up to $1 \mathrm{~cm}$, conspicuously covered by coriaceous elliptic scales (see note 1 ), to 1 by 0.5 $\mathrm{cm}$, scales densely covered with curly hairs. Leaves subopposite, trinerved, coriaceous, below, initially covered with curly hairs then glabrescent below, remnant of curly hairs always present at midrib below; blade not bullate, without

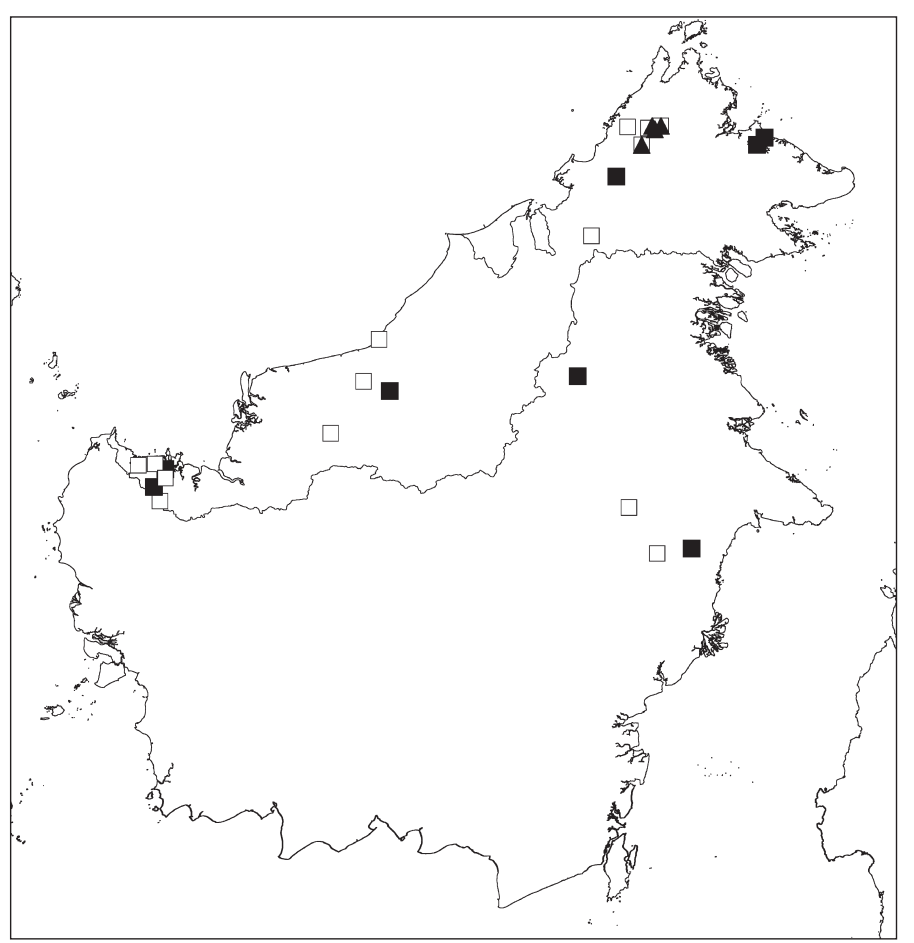

domatia, ovate, oblong ovate, elliptic or lanceolate, (7-)9-16 by (3-)4-6 cm, base cuneate, apex acute; midrib raised on both sides, to $1 \mathrm{~mm}$ broad; lateral veins raised on both sides, extending to leaf tip; major intercostal veins slender, raised, subscalariform, 2-5 $\mathrm{mm}$ apart, less prominent than midrib; minor intercostal veins faint, reticulate; petiole stout, flat above, initially hairy then glabrescent, $0.5-1 \mathrm{~cm}$ long, c. $2 \mathrm{~mm}$ diam. Inflorescences axillary and/or subterminal, stout, paniculatecymose with second or third order branching, 10-17 cm long; rachis 1-2 mm broad, brownish hairy. Flowers drying brownish hairy; pedicels slender, 2-3 mm long; hypanthium $2 \mathrm{~mm}$ high, distinct; perianth lobes elliptic, c. $2 \mathrm{~mm}$ long, appressed hairy on both sides; fertile stamens c. $2.5 \mathrm{~mm}$ long, anthers 4-locular, ovoid with truncate tip, filaments $1 / 4-3 / 4$ the length of the stamen; glands sessile on each side at the middle of filaments; staminodes c. $2 \mathrm{~mm}$ long, sagittate; ovary subglobose, c. $1 \mathrm{~mm}$ across, stigma peltate. Infructescences to $19 \mathrm{~cm}$ long; rachis c. $2 \mathrm{~mm}$ broad, densely hairy. Fruits ellipsoid with pointed tip, c. 10 by $5 \mathrm{~mm}$; cupule cup-shaped, c. $4 \mathrm{~mm}$ high, c. $5 \mathrm{~mm}$ diam, rim entire, not undulating, glabrous; perianth lobes caducous; pedicel stout, 1.5-2 mm long, hairy, glabrescent.

Distribution - Endemic to Borneo, known only in Sabah (Ranau district).

Habitat \& Ecology — In submontane to montane forest, at altitudes above $1200 \mathrm{~m}$.

Notes - 1. The vegetative bud of $C$. sublanuginosum is covered by leafy bracts which fall off as the shoot flushes and matures but unlike the perulate bud in temperate Cinnamomum or $C$. porrectum the bract is not dehiscent and scaly.

2. Cinnamomum sublanuginosum and $C$. woodii are similar in having curly hairs on the leaf blade, major intercostal veins subscalariform and lateral veins extending to the leaf tip. Their inflorescences are hairy and the fruit cupule has a smooth rim.

3. This species is reminiscent of $C$. subavenium but differs by its large leaf size (vs small), prominent major intercostal veins (vs faint) and thick cupule (vs flattish). A specimen from Sabah (SAN 17011) annotated by Kostermans (1970b) as C. sublanuginosum belongs to $C$. subavenium.
Map 9 Distribution of Cinnamomum sublanuginosum Kosterm. ( $\triangle$ ), C. tahijanum Kosterm. ( $\square$ ) and C. verum J.PresI ( $\square$ ). 


\section{Cinnamomum tahijanum Kosterm. - Map 9}

Cinnamomum tahijanum Kosterm. (1970a) 13; J.A.R.Anderson (1980) 223 - Type: Ashton S 15196 (holo BO; iso K, L, SAR, SING), Sarawak, Kuching district, Semengoh Forest Reserve.

Cinnamomum bintulense Kosterm. (1988) 441; J.A.R.Anderson (1980) 223, syn. nov. - Type: Sibat S 24611 (holo L; iso BO, K, KEP, SAN, SAR, SING), Sarawak, Bintulu, Nyabau.

Cinnamomum fouillyi Kosterm. (1988) 442, syn. nov. - Type: Kostermans 4130 (holo L: iso BO, K, SING), Borneo, Kalimantan, East Kutei, Sg. Wain, North of Balikpapan.

Cinnamomum pseudojavanicum Kosterm., nom. nud., in Coode et al. (1996) 151. - Representative specimens: SAN 27491 (KEP, L, SAN, SAR) \& SAN 34508 (KEP, L, SAN, SAR), Sabah, Ranau district, Sosopodon.

Tree 10-20 m tall, 10-38 cm diam. Bark smooth or scaly, greyish brown. Twigs terete, 2-4 $\mathrm{mm}$ diam, apically subangular, densely hairy, yellowish to greyish brown. Terminal buds not perulate, conical, c. $4 \mathrm{~mm}$, densely covered with curly hairs. Leaves opposite or subopposite, trinerved or triplinerved, subcoriaceous, often densely covered with curly hairs or sometimes glabrescens below, if glabrescens, remnant of indumentum always present on midrib; blade not bullate, without domatia, oblong, elliptic, oblong-elliptic, ovate or obovate, (6-)9-16(-21) by $(2.5-) 4-7(-8.5) \mathrm{cm}$, base cuneate to narrowly cuneate, apex conspicuously acuminate, acumen $0.5-2 \mathrm{~cm}$ long; midrib distinctly raised on both sides, c. $1 \mathrm{~mm}$ broad; lateral veins basal, prominent on both sides, extending to the base of acumen; major intercostal veins slender, raised below, subscalariform, 2-6 mm apart; minor intercostal veins reticulate, indistinct; petiole stout, $2-2.5 \mathrm{~cm}$ long, $0.5-1.5 \mathrm{~mm}$ diam, flat above, hairy. Inflorescences axillary and/or subterminal, paniculate-cymose with up to third order branching, 12-17 cm long, greyish brown; rachis $1-2 \mathrm{~mm}$ broad. Flowers drying silky greyish brown, yellowish when fresh, hairy; pedicel 3-4 mm long, to $1 \mathrm{~mm}$ diam; hypanthium c. $1 \mathrm{~mm}$ high; perianth lobes elliptic to ovate, c. 2-3 mm long, densely appressed hairy; fertile stamens c. 2 $\mathrm{mm}$ long, anthers 2- or 4-locular, ovoid with truncate tip, filaments $1 / 3-2 / 3$ the length of the stamen; glands large, sessile, attach at the middle of filaments; staminodes c. $1.5 \mathrm{~mm}$ long, hastate; ovary ellipsoid, c. $1 \mathrm{~mm}$ high, stigma subpeltate. Fruits ellipsoid, c. 5 by $3 \mathrm{~mm}$, glabrous; cupule very shallow, c. 1-3 $\mathrm{mm}$ high, 1-3 $\mathrm{mm}$ diam; perianth lobes persistent, elliptic, c. 3 by $2 \mathrm{~mm}$, appressed pilose; pedicel slender, $4-5 \mathrm{~mm}$ long, c. 1 $\mathrm{mm}$ diam.

Distribution - Endemic to Borneo: Sarawak (Bintulu, Kuching and Tatau districts) and Sabah (Tenom and Ranau districts).

Habitat \& Ecology — In mixed dipterocarp and riverine forest, at $60-1300 \mathrm{~m}$ altitudes.

Vernacular names - Medang (Iban), Medang tija (Malay).

Notes - 1. Cinnamomum bintulense, C. fouillyi and C. pseudojavanicum are conspecific to $C$. tahijanum in having a leaf acumen, subscalariform major intercostal veins and dense curly hairs on the leaves, twig and inflorescence.

2. The type of $C$. bintulense is a young twig with immature inflorescence and leaves ovate and elliptic with shorter acumen (to $0.5 \mathrm{~cm}$ long). The leaves of $C$. tahijanum type are elliptic, oblong and sometimes obovate in shape and with longer acumen $(0.5-2 \mathrm{~cm}$ long). New fertile material that are intermediate between $C$. tahijanum and C. bintulense ( $S$ 64975, S 66766, $S 68476$ ) indicates that the leaf shape is very variable ranging from oblong, elliptic, obovate to ovate.

3. The type specimens of $C$. fouillyi are a sterile young twig with a slight aberration from $C$. tahijanum by having slightly bullate leaves.

4. Coode et al. (1996) listed C. pseudojavanicum, an unpublished species of Kostermans, in the checklist for Brunei plants. The epithet was given and annotated by Kostermans on SAN 27491 and SAN 34508 because of its close resemblance to
C. javanicum but differs in its slender twigs, non-bullate leaves and subscalariform major intercostal veins (vs stout twigs, bullate leaves and scalariform major intercostals veins). However, SAN 27491 and SAN 34508 were cited as C. tahijanum by Kostermans (1970a). These two specimens only differ from C. tahijanum by their slender twigs, inflorescences and leaf stalks. They are found at high altitude (c. $1300 \mathrm{~m}$ ) and are likely a highland variation of $C$. tahijanum.

\section{Cinnamomum verum J.Presl - Map 9}

Cinnamomum verum J.Presl (1825) 36; Kosterm. (1965) 141; (1982) 14; (1985) 126. - Type: Laurus cinnamomum L., Herb. Cliffort: 154, Laurus 6, sheet 6B (lecto BM, barcode BM000558701, here designated) (see Jarvis 2007: 16 on lectotypification).

Cinnamomum zeylanicum Blume (1826) 568; Merr. (1921) 273; Masam. (1942) 309. - Type: Blume s.n. (lecto L, barcode L0036032, here designated), Java.

Cinnamomum alexei Kosterm. (1969) 454, syn. nov. - Type: Buwalda 3618 (holo BO; iso L), Java, Tjampaka near Tjidadap, Mt Karang.

Tree to 6-18 m tall, 20-30 cm diam. Bark smooth or fissured, greyish brown; inner bark strongly scented with cinnamon smell. Sapwood yellowish. Twigs stout, terete, 2-3 mm diam, apically angular, glabrous, dark brown. Terminal buds not perulate, conical, c. $2 \mathrm{~mm}$, densely covered with straight appressed hairs. Leaves opposite or subopposite, drying pale greenish brown, triplinerved or trinerved, coriaceous, glabrous below; blade not bullate, without domatia, ovate, $8-12(-14)$ by $3-6(-9) \mathrm{cm}$, base cuneate or rounded, apex acute with blunt tip; midrib raised on both sides, to $1 \mathrm{~mm}$ broad; lateral veins raised on both sides, extending to $2 / 3-3 / 4$ length of blade; major intercostal veins finely, raised, subscalariform, 3-10 mm apart, less prominent than midrib; minor intercostal veins faint, reticulate; petiole slender, flat above, glabrous, $0.5-2 \mathrm{~cm}$ long, 1-2 mm diam. Inflorescences axillary and/or subterminal, paniculate-cymose with first to second order branching, to $12 \mathrm{~cm}$ long; rachis $1-1.5 \mathrm{~mm}$ broad, appressed hairy. Flowers drying greyish appressed hairy; pedicel slender, c. $5 \mathrm{~mm}$ long; hypanthium 1-2 mm high; perianth lobes lanceolate to elliptic, 3-4 mm long, appressed hairy on both sides; fertile stamens $2-3 \mathrm{~mm}$ long, anthers 4-locular, filaments c. 3/4 the length of the stamen; glands sessile attached on each side at the middle of filaments, flattish; staminodes $1.5-2 \mathrm{~mm}$ long, hastate; ovary globose, c. $1.5 \mathrm{~mm}$ diam, stigma trilobed. Infructescences to $12 \mathrm{~cm}$ long. Fruits ellipsoid, $10-13$ by $7 \mathrm{~mm}$; cupule cup-shaped, thick, c. $7 \mathrm{~mm}$ high, $4 \mathrm{~mm}$ diam, appressed hairy, glabrescent; perianth lobes persistent, indurate, apex truncate, c. 2 by $2 \mathrm{~mm}$; pedicel stout, 3-5 mm long, appressed hairy.

Distribution - Cultivated in Sarawak (Kuching district), Sabah (Keningau and Sandakan districts) and Kalimantan. This species originated from Sri Lanka and is widely cultivated in the tropics as a source of cinnamon.

Habitat \& Ecology — In Borneo cultivated at low altitude.

Uses - The bark is used as a spice, the oil from the bark is used as a flavouring agent in food and pharmaceutical industries, as medicine and in the perfumery industry (for more detail on usage see Flach \& Siemonsma 1999).

\section{INCOMPLETELY KNOWN SPECIES}

\section{Cinnamomum woulfei Kosterm.}

Cinnamomum woulfei Kosterm. (1970b) 75. - Type: Endert 4703 (holo BO; iso $\mathrm{K}, \mathrm{L})$, East Kalimantan, West Kutei, Telen river.

Medium-sized tree to $18 \mathrm{~m}$ tall, to $30 \mathrm{~cm}$ diam. Bark unknown. Twigs slender, angular, c. $2 \mathrm{~mm}$ diam, apically angular, densely hairy. Terminal buds not perulate, conical, c. $2 \mathrm{~mm}$ long, densely covered with curly hairs. Leaves subopposite, triplinerved, thinly 
coriaceous, densely covered with curly hairs below, glabrescent, remnant of indumentum always present near midrib below; blade without domatia, oblong elliptic, $10-35$ by $3-5.5 \mathrm{~cm}$, base cuneate, apex possibly acute (gnawed), tapering gradually to tip; midrib raised and prominent on both sides, c. $1 \mathrm{~mm}$ wide; lateral veins raised and prominent on both sides, extending to the base of leaf tip; major intercostal veins raised below, slender, subscalariform, c. $3 \mathrm{~mm}$ apart; minor intercostal reticulate, indistinct; petiole slender, terete, 6-10 mm long, c. $1 \mathrm{~mm}$ diam. Inflorescences axillary, paniculate-cymose with up to second order branching, 5-14 cm long; rachis slender, 1-2 mm broad. Flowers drying silky brown, hairy; pedicel $3-3.5 \mathrm{~mm}$ long, to $1 \mathrm{~mm}$ diam; hypanthium c. $1.5 \mathrm{~mm}$ high; perianth lobes ovate, c. 2-2.5 mm long, densely appressed hairy; fertile stamens c. $2 \mathrm{~mm}$ long, anthers 4-locular, ovoid with truncate tip, filaments $2 / 3$ the length of the stamen; glands large, sessile, attached at the base of filaments; staminodes c. $1 \mathrm{~mm}$ long, hastate; ovary ellipsoid, c. $1 \mathrm{~mm}$ high, stigma subpeltate. Fruits unknown.

Distribution - Endemic to Borneo, known only from East Kalimantan.

Note - This species is only known from the type specimen. More material is needed, particularly the fruit, which is an important diagnostic character for Cinnamomum.

\section{EXCLUDED SPECIES}

Cinnamomum alternifolium Kosterm. (1970b) 30; Beaman et al. (2001) 398. - Type: Clemens 28812 (holo BO; iso BM, L, NY), Borneo, Sabah, Ranau district, Tenompok.

Note - This species is described from a young sterile specimen. The leaves are alternately arranged. Further material is needed to confirm the identification of this species. Kostermans later annotated the type specimen as Lindera alternifolia.

Acknowledgements I would like to express my deepest gratitude to the curators of the BO, K, KEP, L, P, PNH, SAN, SAR, SING and SNP herbaria for their assistance. I would like to thank the Director of the National Herbarium Leiden for permission to examine the unpublished manuscript of A.J.G.H. Kostermans on Cinnamomum. I am deeply grateful to Engkik Soepadmo for his guidance and advice during the study and preparation of this paper. I am also grateful to Ruth Kiew and Julia Sang for their encouragements and help for sourcing references and materials. A special thanks to Sarah Eftonga for proofreading this article. I would like to thank the two anonymous reviewers for their comments. This revision was partially funded by the author and the IRPA Research Grant 30-08-01-01-005 (the Tree Flora of Sabah and Sarawak Project)

\section{REFERENCES}

Anderson JAR. 1980. A checklist of the trees of Sarawak. Forest Department Sarawak.

Argent G, Saridan A, Campbell EJF, Wilkie P. 1997. Manual of the larger and more important non dipterocarp trees of Central Kalimantan Indonesia 1. Forest Research Institute, Samarinda.

Beaman JH, Anderson C, Beaman RS. 2001. The plants of Mount Kinabalu 4. Natural History Publications (Borneo) Sdn. Bhd.; Kew, Royal Botanic Gardens.

Blume CL. 1823. Catalogus. Published by the author, Batavia.

Blume CL. 1826. Conspectus generum laurinaearum javanicarum. Bijdragen tot de Flora van Nederlandsch Indië. Lands Drukkerij, Batavia.

Blume CL. 1834. Eenige waarnemingen omtrent den Culilawanboom van Rumphius. Tijdschrift voor Natuurlijke Geschiedenis en Physiologie 1: 45-65.

Blume CL. 1836. Rumphia 1. Sulpke, Leiden, Amsterdam.

Blume CL. 1851. Laurineae. Museum botanicum Lugduno-Batavum 1, 21: 322-336. Brill, Lugduni-Batavorum.

Browne FG. 1955. Forest trees of Sarawak and Brunei and their products. Government Printing Office, Kuching.

Burgess PF. 1966. Timber of Sabah, Sabah forest record 6. Forest Department of Sabah.
Burkill IH. 1966. A dictionary of the economic products of the Malay Peninsula 1. Ministry of Agriculture and Cooperatives, Kuala Lumpur.

Cammerloher H. 1925. Die Cinnamomum-arten von Niederlandisch-Ostindien. Bulletin du Jardin Botanique Buitenzorg 3, 7: 446-496.

Chanderbali ASH, Van der Werff H, Renner SS. 2001. Phylogeny and historical biogeography of Lauraceae: evidence from the chloroplast and nuclear genomes. Annals of the Missouri Botanical Garden 88: 104-134.

Coode MJE, Dransfield J, Forman LL, Kirkup DW, Said IM. 1996. A checklist of the flowering plants and gymnosperm of Brunei Darussalam. Ministry of Industry and Primary Resource Brunei; Kew, Royal Botanic Gardens.

Dandy JE. 1967. Index of generic names of vascular plants 1753-1774. Regnum Vegetabile 51. IAPT, Utrecht.

Elmer M. 1910. Lauraceae from Mt Apo and Mt Giting-Giting. Leaflets of Philippine Botany 2: 703-728.

Flach M, Siemonsma JS. 1999. Cinnamomum verum. In: De Guzman CC Siemonsma JS (eds), Plant Resources of South-East Asia 13: 99-104.

Gamble JS. 1910. New Lauraceae from the Malayan region II. Bulletin of Miscellaneous Information, Royal Botanic Gardens, Kew: 218-228.

Gamble JS. 1912. Lauraceae: Materials for a flora of the Malayan Peninsula. Journal of the Asiatic Society of Bengal 75, 2: 35-202.

Hayata B. 1913. Icones plantarum Formosanarum. Taihoku.

Heine H. 1953. Diagnoses novae plantarum in Borneo septentrionali a J. et M.S. Clements lectarum par II. Mitteilungen der Botanischen Staatssammlung München 1: 208-217.

Hooker WJ. 1827. Exotic flora. Blackwood, Edinburgh.

Ibrahim J, Wiselius SI, Lim SC, Sosef MSM. 1995. Cinnamomum. In: Lemmens RHMJ, Soerianegara I, Wong WC (eds), Plant resources of SouthEast Asia 5, 2: 130-140.

Jack W. 1820. Description of Malayan plants. Malayan Miscellanies 1, 5: $1-49$.

Jarvis C. 2007. Order out of chaos, Linnaean plant names and their types. The Linnean Society of London in association with the Natural History Museum, London.

Joseph T, Wong KM. 1995. A Sabah gazetteer. Sabah Forestry Department and Forest Research Institute Malaysia.

Keßler PJA, Sidiyasa K. 1994. Trees of the Balikpapan-Samarinda area, East Kalimantan, Indonesia: a manual to 280 selected species. Tropenbos Foundation Series. Backhuys Publishers, Leiden.

Klucking E.P. 1987. Leaf venation pattern 2 - Lauraceae. Crammer, Berlin. Kochummen KM. 1989. Lauraceae. In: Ng FSP (ed), Tree flora of Malaya 4: 98-178. Longman, Kuala Lumpur.

Kostermans AJGH. 1952. A historical survey of Lauraceae II. Journal for Scientific Research in Indonesia 1: 14-28.

Kostermans AJGH. 1957. Lauraceae. Reinwardtia 4: 193-256.

Kostermans AJGH. 1964. Bibliographia Lauracearum. Departemen Urusan Research Nasional, Jakarta.

Kostermans AJGH. 1965. Miscellaneous botanical notes IV. Reinwardtia 7: 141

Kostermans AJGH. 1969. Materials for a revision of Lauraceae II. Reinwardtia 7: 451-536.

Kostermans AJGH. 1970a. An new Bornean species of Cinnamomum Sch. Reinwardtia 8: 13-15.

Kostermans AJGH. 1970b. Materials for a revision of Lauraceae III. Reinwardtia 8: 21-196.

Kostermans AJGH. 1982. Lauraceae. In: Flore des Mascareignes 153: 116.

Kostermans AJGH. 1985. The South Indian species of Cinnamomum Schaeffer (Lauraceae). Bulletin of the Botanical Survey of India 25: 90-133.

Kostermans AJGH. 1986. A monograph of the genus Cinnamomum Schaeff. (Lauraceae) I. Gingkoana 6: 1-171.

Kostermans AJGH. 1988. Materials for a revision of Lauraceae V. Reinwardtia 10: $439-469$.

Li XW, Li HW, Van der Werff H. 2008. Cinnamomum. In: Wu ZY, Raven PH, Hong DY (eds), Flora of China 7: 166-187. Science Press, Beijing, and Missouri Botanical Garden Press, St. Louis.

Mabberley DJ. 2008. Mabberley's plant-book: A portable dictionary of plants, their classifications and uses, third edition. Cambridge University Press

Marsden W. 1811. The history of Sumatra. Published by the author, London.

Masamune G. 1942. Enumeratio phanerogamarum Bornearum. Taihoku Imperial University, Taihoku, Formosa.

Meisner CF. 1864. Lauraceae. In: De Candolle A (ed), Prodromus systematis naturalis regni vegetabilis 15, 1: 1-260. Sumptibus Victoris Masson et Filii, Paris.

Merrill ED. 1921. A bibliographic enumeration of Bornean plants. Journal of the Straits Branch of the Royal Asiatic Society, special no. Fraser \& Neave, Singapore. 
Merrill ED. 1929. Plantae elmerianae borneenses. University of Carlifornia Publication in Botany 15: 1-316.

Miquel FAW. 1858. Flora van Nederlandsch Indie 1, 2. Van der Post, Amsterdam.

Miquel FAW. 1860. Flora van Nederlandsch Indie, Suppl. 1, Sumatra. Van der Post, Utrecht.

Miquel FAW. 1864. Cinnamomum. Annales Musei Botanici Lugduno-batavi 1: 257-270. Van der Post, Amsterdam.

Mohizah M, Julia S, Soh WK. 2006. A Sarawak gazetteer. Sarawak Forestry Department \& Forest Research Institute Malaysia.

Nakai T. 1939. Flora Sylvatica Koreana 22, 24.

Nees von Esenbeck CG. 1831. Laurinae Indiae Orientalis. In: Wallich N, Plantae asiaticae rariores: 58-76. Treuttel \& Würtz, London.

Nees von Esenbeck CG. 1836. Systema Laurinarum. Sumptibus Veitii et Sociorum, Berlin

Nees von Esenbeck CG, Nees von Esenbeck TLF. 1823. De cinnamomo disputatio. Bonn.

Nguyên KD, Tran H, Siemonsma JS. 1999. Cinnamomum. In: De Guzman CC, Siemonsma JS (eds), Plant resources of South-East Asia 13: 94-99.

Nirmal Babu K, Ravindran PN, Shylaja M (eds). 2003. Cinnamon and Cassia, the genus Cinnamomum. CRC Press, USA.

\section{IDENTIFICATION LIST}

The number after each collection refers to the following Cinnamomum species.

$$
\begin{aligned}
& 1=\text { C. angustitepalum } \\
& 2=\text { C. burmannii } \\
& 3=\text { C. calciphilum } \\
& 4=\text { C. corneri } \\
& 5=\text { C. crassinervium } \\
& 6=\text { C. cuspidatum }
\end{aligned}
$$

$$
\begin{aligned}
7 & =\text { C. grandifolium } \\
8 & =\text { C. iners } \\
9 & =\text { C. javanicum } \\
10 & =\text { C. kerangas } \\
11 & =\text { C. kinabaluense } \\
12 & =\text { C. lawang }
\end{aligned}
$$

Presl J. 1825. Laurinae. In: Von Berchthold F, Presl J (eds), O Prirozenosti Rostlin aneb rostlinar 2: 29-72. Endersa, Prague.

Ridley HN. 1924. The Flora of the Malay Peninsula 3. Reeve, London.

Robinson CB. 1912. Roxburgh's Hortus Bengalensis. The Philippine Journal of Science 7: 411-419.

Rohwer JG. 1993. Lauraceae. In: Kubitzki K, Rohwer JG, Bittrich V (eds), The families and genera of vascular plants 2: 366-390. Springer, Berlin, Heidelberg, New York.

Roxburgh W. 1814. Hortus Bengalensis. Mission Press, Serampore.

Roxburgh W. 1832. Flora Indica, ed. 1832, 2. Thacker, London.

Schaeffer JC. 1760. Botanica expeditior. Weiss, Regensburg.

Smythies BE. 1965. Common Sarawak trees. Borneo Literature Bureau, Kuching.

Sprengel KPJ. 1825. Systema vegetabilium 3. Librariae Dieterichianae, Göttingen.

Teijsmann JE, Binnendijk S. 1866. Catalogus plantarum quae in Horto Botanico Bogoriensi coluntur. Lands-Drukkerij, Batavia.

Van der Werff H. 2001. An annotated key to the genera of Lauraceae in the Flora Malesiana region. Blumea 46: 125-140.

Voigt JO. 1845. Hortus Suburbanus Calcuttensis. Bishop's College Press, Calcutta.
Afriastini 1139: 12 - Ampon A 475: 2 - Angian 10493: 23 - Anonymous s.n. (L0035729): 2; 3301 (1893): 10 - Anonymous (native collector) 130: 8; 1111: 26 - Arumpad A 1702: 17; 1716: 2; 1720: 17

bb series 2410: 20; 2567: 20; 2769: 20; 5700: 17; 13925: 17; 14073: 22; 14079: 20; 16874: 20; 20713: 14; 23405: 17; 24524: 12; 26021: 10; 28100 : 12; 28118: 20; 29036: 20; 29208: 20; 29420: 17; 31189: 17 - Beccari 270: 26 - Blume s.n. (L0035722, L0035724, L0035745): 2; s.n. (L0035822, L0035823): 8; s.n. (L0035826, L0035827): 9; s.n. (L0036032): 26; s.n. (sheet L 905229197): 20; 870: 20; 1440: 9 - BNBFD series 517: 26; 1753: 23; 1876: 26; 3159: 5; 3259: 5; 3652: 23 - BRUN series 369: 16; 793: 9; 1508: 9; 1899: 1; 3124: 9; 5047: 16; 5285: 5 - Buwalda 3618: 26 - Buxton A 544: 19.

Charington 3861: 18 - Chew CWL 1414: 1 - Christensen 252: 9; 350: 9; 376 : 2; 416: 18 - Church et al. 421: 9; 1633: 19; 1872: 9; 1981: 9 - J. \& M.S. Clemens 20182: 20; 20225: 23; 22194: 19; 28380: 17; 28826: 23; 29615: 23; 30227: 23; 31078: 11; 31108: 21; 31607: 17; 32690: 11; 33689: 11; 34171: 11 - Clemente 5978: 2 - Cuadra A 1224: 23; 1283: 23; 3198: 26.

De Vogel 2038: 26 - De Vriese s.n. (K000227502): 8; s.n. (L0035970): 20 - Ding Hou 349: 25 - Doinis DS 18: 23; 311: 23; 735: 9.

Egon A 336: 26; 922: 17 - Elmer 11105: 2; 20757: 23; 20865: 23 - Endert 149 E ip 841: 20; 1752: 17; 3687: 18; 3840: 25; 4703: 28; 5074: 19 - Enggoh 10182: 18.

FMS series 10182: 18; 34235: 19; 34538: 23; 35167: 19; 36309: 17; 41167: 9; 48956: 18 - FRI series 19831: 19; 36251: 18

Grashoff 564: 20 - Griffith 4240: 23

Hallier 1463: 19; 2469: 1 - Hansen 734: 5 - Haviland \& Hose 3290: 10 - Hewitt s.n. (Aug 1908): 12 - Hoare 99: 2; 207: 2.

Jaheri 533: 7 - Jirin 21: 23 - Junghuhn s.n. (L0035975, L0035976): 20 - Jusimin 514: 18; JD 389: 18

Keith 5999: 2; 9957: 23; 48744: 23 -KEP 79313: 1; 80421: 17; 105186: 19 ; 110414: 19 - King 8515: 20 - Kitayama SPN 4486: 11 - Kokawa \& Hotta 5262: 11 - Korthals s.n. (L0035816, L0035817, L0035818, L0035819): 8; (L0035920, L0035921, L0035922, U0002664): 16; s.n. (L0035989, L0035991, L0119675, U0002676): 22; s.n. (L Acc. No. 905220161): 22 - Kostermans 4130: 25; 4550: 19; 4559: 19; 5283: 23; 5864: 17; 6123: 17; 6181: 2; 6781: 17; 7330: 14; 7389: 14; 7504: 9; 7509: 17; 7621: 14 ; 7732: 14; 7761: 9; 8929: 9; 9283: 1; 9622: 19; 9815: 20; 12949: 1; 12974: 1; 12981: 16; 13075 A: 1; 13067: 16; 13559: 17; 21203: 23; 21651: 23; 21657: 23 - Kuhl \& Van Hasselt s.n. (L0035821): 8.

Labohm 40: 17; 1891: 26; 2089: 14 - Lei 151: 2 - Leighton 536: 23 - Ligon 41: 23 - Lugas LL 1101: 23; 1939: 23; 2589: 23
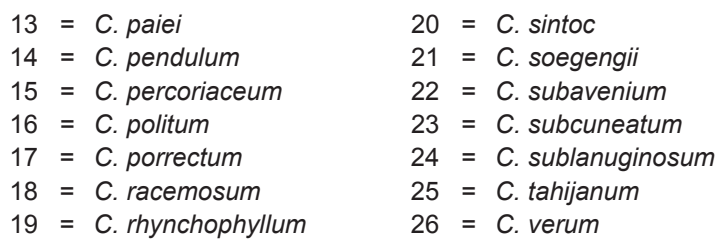

Maidum 207: 23 - Majid A 470: 17 - Matus 33: 23 - McDonald 3514: 9 - Meijer 495: 17 - Mogan A 609: 17 - Mohd. Shah 1575: 6 - Motley 796: 22 - Muller s.n. (L0035758): 5.

Nagasawa 155: 2 - Niga NN 109: 23 - Noordin A 2251: 26 - Nooteboom \& Chai 2102: 22

Ogata 10443: 19 - Omar 398: 8

PBU series 360: 14 - Pereira JTP 379: 9; 508: 18 - Puasa 36456: 23. Reinwardt s.n. (L0035811): 8; s.n. (L0035833): 9; s.n. (L0035825): 20 - Reza RA 91: 23; 414: 23; 539: 23 - Ridley 4823: 22; 14516: 8 - Riswan KP 035: 14 - Rosli 3391: 5 - Roxburgh s.n. (P00476750): 17 - RSNB series 8: 14; 2687: 23; 4750: 21; 4983: 17; 7019: 22; 7036: 24 - Rumutom MR 175: 23.

S series 9: 17; 10: 23; 22: 10; 1123: 6; 1141: 6; 1293: 16; 2288: 10; 3469: 5; 3711: 18; 3810: 18; 4726: 3; 4751: 10; 4834: 26; 7803: 16; 8698: 18 10028: 9; 10593: 1; 13815: 3; 14956: 25; 15027: 25; 15196: 25; 15285: 3; 16242: 1; 16253: 1; 18099: 14; 18310: 18; 18388: 16; 19145: 8; 20031: 9; 20039: 22; 20246: 3; 22108: 14; 24611: 25; 25208: 9; 25616: 3; 26395: 15 27141: 5; 28929: 10; 29332: 13; 29361: 10; 30031: 26; 32509: 25; 32529: 25; 32786: 5; 32789: 7; 32886: 6; 32912: 9; 32952: 5; 32972: 25; 35273 17; 36908: 5 ; 37169: 1; 37382: 3; 37932: 14; 37997: 25; 38157: 14; 39484 6; 41520: 25 ; 43326: 3 ; 43382: 9 ; 43551: 5 ; 44046: 22; 44252: 14; 45047 15; 45066: 15; 47323: 16; 47357: 16; 47394: 23; 48919: 5; 50966: 11; 55227: 25; 57046: 9; 57064: 9; 57250: 9; 57289: 5; 57435: 19; 58625: 5; 59101: 23; 59315: 23; 59336: 23; 60555: 16; 60606: 18; 64283: 5; 64975 25; 66427: 13; 66766: 25; 68476: 25; 68612: 23; 68630: 5; 68813: 13; 73316: 19; 76343: 14; 81849: 23; 91386: 7 - S A 3861: 18 - Sales 4309: 23; 38686: 23 - SAN series 15301: 20; 15302: 2; 16268: 9; 16377: 24; 16706: 21 ; 17011: 22; 17842: 18; 18804: 23; 19068: 23; 21007: 9; 21281 23; 21517: 26; 22407: 14; 24002: 18; 26414: 17; 26737: 18; 27004: 17; 27271: 23; 27491: 25; 28012: 4; 28167: 16; 28543: 2; 28672: 17; 29076 : 21; 30548: 23; 31346: 17; 31460: 23; 31866: 11; 33074: 20; 34171: 23; 34508: 25; 34867: 23; 35819: 23; 35984: 23; 36322: 23; 36443: 23; 36493: 23; 37019: 19; 38435: 24; 38652: 22; 38664: 17; 38684: 17; 38731: 4 41103: 9; 41798: 21; 42691: 17; 43587: 9; 44211: 17; 44491: 24; 44576 : 2; 44579: 2; 46703: 9; 47008: 17; 47917: 4; 48142: 18; 48459: 23; 48700: 21 ; 48737: 21; 49235: 23; 49308: 21; 49373: 17; 49511: 17; 49758: 23 ; 49804: 17; 51424: 9; 52364: 2; 53348: 9; 53801: 21; 56217: 19; 60580: 17; 60664: 4; 60740: 25; 61755: 22; 61968: 24; 62018: 4; 62142: 9; 64721: 23; 65130: 22; 66838: 11; 68131: 22; 68152: 23; 72171: 23; 72196: 9; 73517: 18; 73673: 17; 74126: 23; 75846: 24; 76039: 17; 76170: 23; 76182: 18; 76227: 18; 76442: 4; 76449: 4; 76933: 23; 77146: 17; 77154: 23; 77445: 23; 78628: 23; 79730: 9; 80446: 23; 80764: 23; 81888: 23; 82044: 23; 
82718: 17; 82801: $17 ; 82838: 2 ; 84343: 17 ; 85168: 19 ; 85386: 9$; 85469: 2; 85613: 17; 85725: 17; 86071: 18; 89171: 23; 89235: 9; 89280: 23; 89440: 17; 89478: 22; 89777: 23; 90304: 23; 90308: 17; 90444: 23; 92751: 23 ; 92752: 23; 94115: 23; 94335: 23; 94393: 18; 95940: 23; 96109: 9; 96575: 23; 97377: 23; 97454: 5; 97545: 23; 97649: 9; 98106: 9; 98182: 9; 98183: 9; 99540: 23; 100706: 9; 100978: 9; 101911: 23; 107829: 23; 108804: 5; 108971: 23; 110467: 5; 110618: 23; 111566: 23; 116074: 23; 117637: 23; 117836: 18; 117941: 23; 118093: 9; 119007: 23; 119805: 23; 119916: 17 ; 120428: 9; 120498: 18; 120554: 23; 120747: 23; 121070: 23; 121744: 9; 122026: 18 ; 122258 : 22; 122534: 23; 122639: 9; 123212: 23; 124560: 23 ; 124956: 23; 127717: 18; 127910: 5; 128194: 23; 128308: 23; 128852: 23; 129632: 18; 130764: 9; 130781: 25; 130936: 23; 131413: 18; 131878: 9 ;
131920: 23; 131942: 9; 132190: 2; 132488: 23; 133927: 9; 134088: 23 134594: 17; 136857: 18; 137089: 9; 138868: 22; 140041: 25; 141553: 23 - Schuitemaker 173: 12 - Scortechini 1228: 6 - SFN series s.n. (Sappi): 26; 26852: 4 - Sidikan MB 232: 18 - SNP series 514: 18; 2834: 23; 3057: 18 ; 6778: 23 - Soepomo 19: 17 - Soibeh 641: 2 - Spanoghe s.n. (L0035813): 8 - Sugau JBS 126: 22; 153: 9.

Tadong 197: 23; 242: 17; 264: 23 - Teijsmann s.n. (L0035815): 8; 1016: 23; 1023: 23; 1031: 19; 1032: 22; 1037: 22; 1053: 22; 4550: 19; 8687: 9.

Umbol 5261: 2.

Wallich Numer. List 2581A: 2; 2582C: 8 - Winkler 3331: 23 - Wood 1975: 23 - Wray 2629: 20; 3664: 6 .

Zutri 17: 19 - Zwan 932: 17.

\section{INDEX TO NAMES}

Accepted names are in roman type, the synonymy, dubious and excluded names in italics. The numbers refer to the species number used in this revision. excl. $=$ excluded; inc. $=$ incompletely known .

\author{
Camphora \\ inodora Blume ex Miq. 17 \\ parthenoxylon (Jack) Nees 17 \\ porrecta (Roxb.) Voigt 17 \\ Cinnamomum Schaeff. [p. 241] \\ alexei Kosterm. 26 \\ alternifolium Kosterm. excl. \\ angustitepalum Kosterm. 1 \\ arbusculum Kosterm. 3 \\ bintulense Kosterm. 25 \\ borneense Meisn. 22 \\ borneense Miq. 22 \\ burmannii (Nees \& T.Nees) Blume 2 \\ calciphilum Kosterm. 3 \\ callophyllum Reinw. ex Nees 20 \\ calyculatum Miq. 8 \\ camphoratum Blume 20 \\ caudifolium Kosterm. 6 \\ chinense Blume 2 \\ cinereum Gamble 20 \\ coriaceum Cammerl. 20 \\ corneri Kosterm. 4 \\ crassinervium Miq. 5 \\ culitlawan Blume var. celebricum 22 \\ cuspidatum Miq. 6 \\ cyrtopodum Miq. 22 \\ dasyanthum Miq. 8 \\ dictyoneuron Kosterm. 18 \\ endlicheriicarpum Kosterm. 5 \\ eucalyptoides Nees 8 \\ floribundum Miq. 22 \\ fouillyi Kosterm. 25 \\ glabrescens Miq. 22 \\ gracile Miq. 23 \\ graciliflorum Gamble 6 \\ grandifolium Cammerl. 7 \\ grandis Kosterm. 21 \\ griffithii Meisn. 23 \\ hainanense Nakai 2 \\ iners Reinw. ex Blume 8 \\ var. angustifolium 8 \\ var. latum Blume 8 \\ inodorum (Blume ex Miq.) Meisn. 17 \\ javanicum Blume 9 \\ var. neglectum Meisn. 8 \\ kerangas Kosterm. 10 \\ kiamis Nees 2 \\ kinabaluense Heine 11 \\ lampongum Miq. 19 \\ lawang Kosterm. 12 \\ laxiflorum Meisn. 20 \\ laxiflorum Meisn. 8 \\ macrostemon Hayata 2 \\ malayanum Kosterm. 6
}

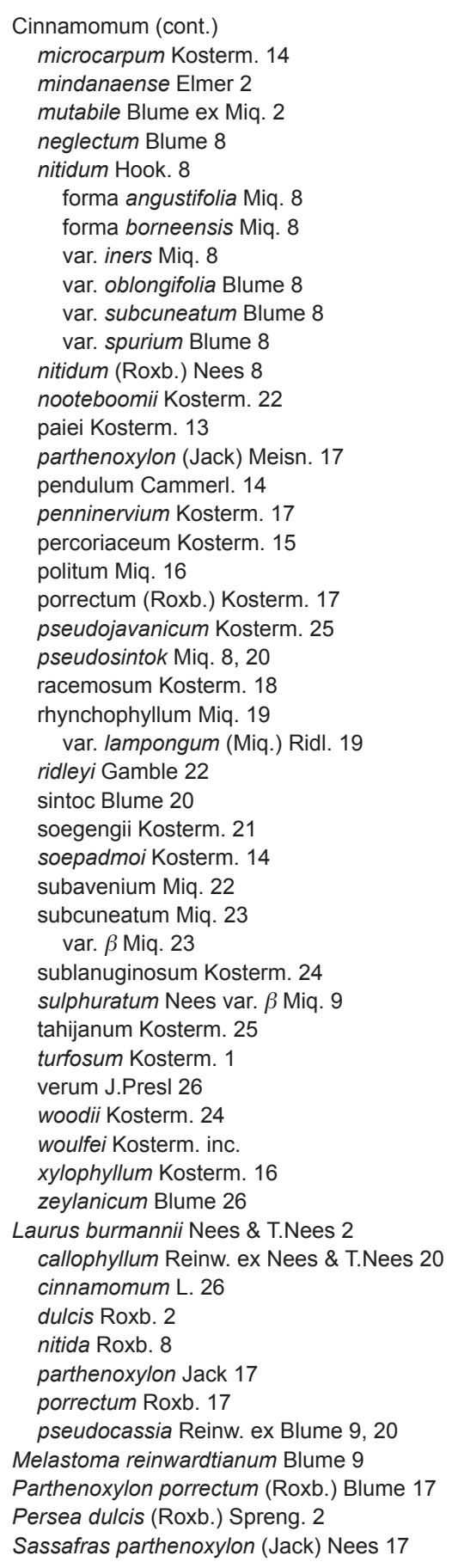

